U.S. Geological Survey Groundwater Resources Program and prepared in cooperation with the Oregon Water Resources Department

\title{
Groundwater Status and Trends for the Columbia Plateau Regional Aquifer System, Washington, Oregon, and Idaho
}

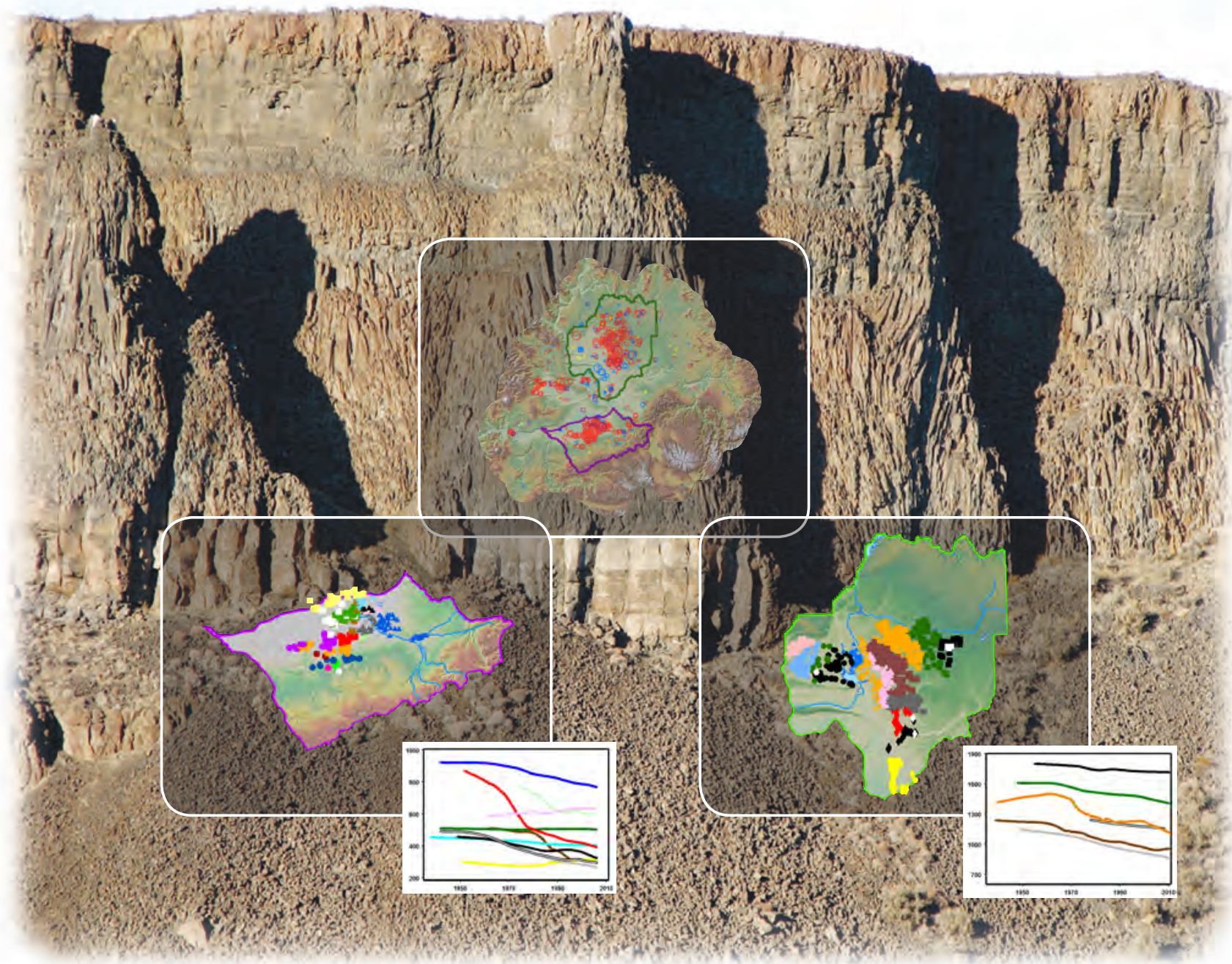

Scientific Investigations Report 2012-5261 
Cover: Lower left: Map showing select groups of wells with similar hydraulic response within portions of the Umatilla Basin, Oregon. Hydrographs showing the trend lines of spring median water levels for select groups of wells with similar hydraulic response in the Umatilla Basin, Oregon (East-West groups). (See figures 10 and $11 B$, respectively, in the report.)

Center foreground: Map showing distribution of groundwater-level trends in the Columbia Plateau Regional Aquifer System for the period 1968-2009. Red circles indicate groundwater-level declines, yellow circles indicate little or no change in groundwater levels, and blue circles indicate groundwater-level rises. Circle size is representative of magnitude of change.

(See figure 8 in the report.)

Lower right: Map showing select groups of wells with similar hydraulic response within portions of the Palouse Slope and the Columbia Basin Ground Water Management Area, Washington. Hydrographs showing the trend lines of spring median water levels for groups of wells with similar hydraulic response in the vicinity of the Palouse Slope and the Columbia Basin Ground Water Management Area, Washington (Eastern Flowpath groups).

(See figures 15 and 17, respectively, in the report)

Background: Photograph of Frenchman's Coulee in the vicinity of Quincy, Washington. (Photograph taken by Peter Prehn, private citizen, 2008. Used with permission.) 


\section{Groundwater Status and Trends for the Columbia Plateau Regional Aquifer System, Washington, Oregon, and Idaho}

By Erick R. Burns, Daniel T. Snyder, Jonathan V. Haynes, and Michael S. Waibel

U.S. Geological Survey Groundwater Resources Program and

prepared in cooperation with the Oregon Water Resources Department

Scientific Investigations Report 2012-5261 


\title{
U.S. Department of the Interior \\ KEN SALAZAR, Secretary \\ U.S. Geological Survey \\ Marcia K. McNutt, Director
}

\author{
U.S. Geological Survey, Reston, Virginia: 2012
}

For more information on the USGS - the Federal source for science about the Earth, its natural and living resources, natural hazards, and the environment, visit http://www.usgs.gov or call 1-888-ASK-USGS.

For an overview of USGS information products, including maps, imagery, and publications, visit http://www.usgs.gov/pubprod

To order this and other USGS information products, visit http://store.usgs.gov

Any use of trade, product, or firm names is for descriptive purposes only and does not imply endorsement by the U.S. Government.

Although this report is in the public domain, permission must be secured from the individual copyright owners to reproduce any copyrighted materials contained within this report.

Suggested citation:

Burns, E.R, Snyder, D.T, Haynes, J.V., and Waibel, M.S., 2012, Groundwater status and trends for the Columbia Plateau Regional Aquifer System, Washington, Oregon, and Idaho: U.S. Geological Survey Scientific Investigations Report 2012-5261, 52 p., http://pubs.er.usgs.gov/publication/sir20125261. 


\section{Contents}

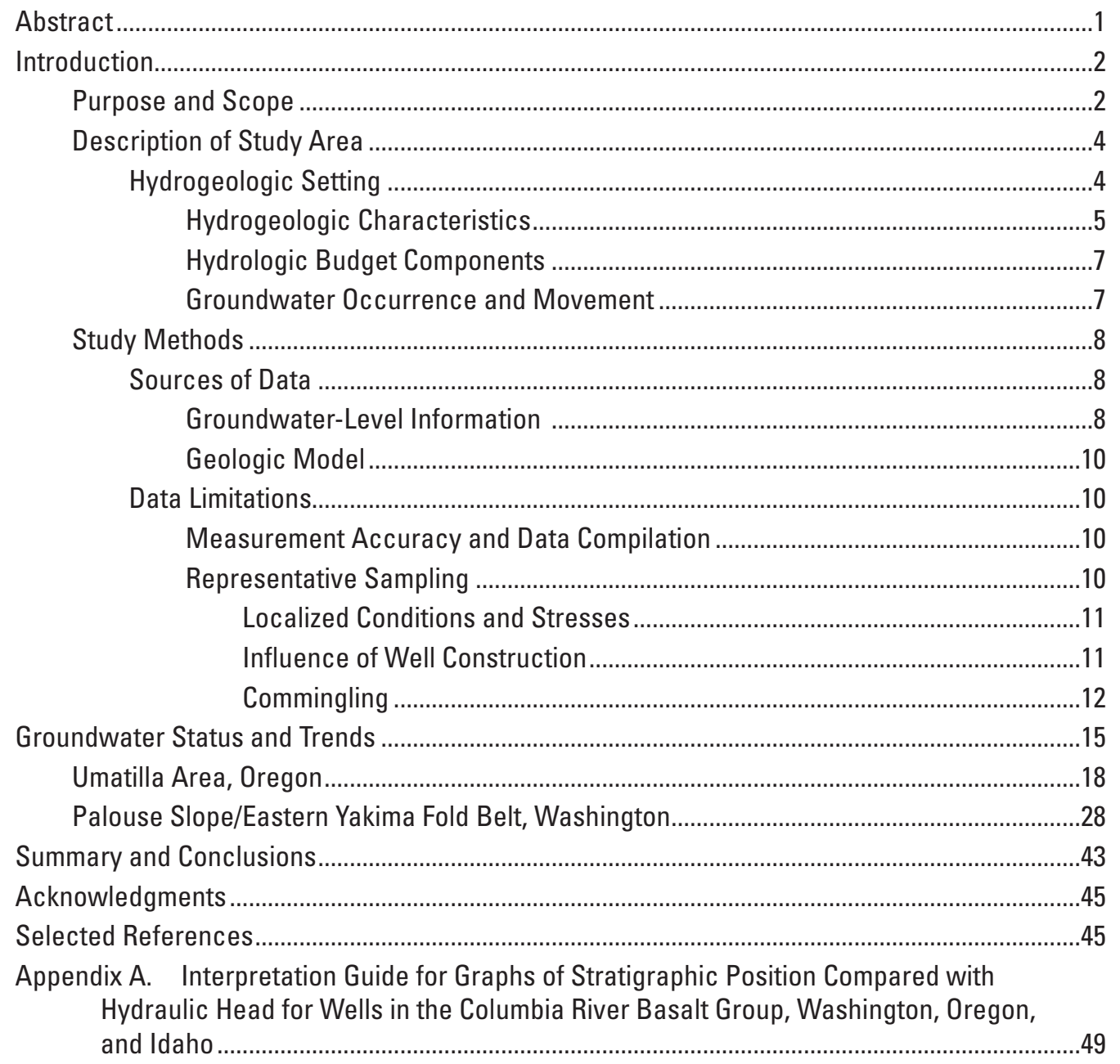




\section{Figures}

Figure 1. Map showing location of Columbia Plateau Regional Aquifer System of Washington, Oregon, and Idaho

Figure 2. Map showing surficial geology and structures of the Columbia Plateau Regional Aquifer System, Washington, Oregon, and Idaho

Figure 3. Map showing locations of wells with usable water-level data within or immediately adjacent to the Columbia Plateau Regional Aquifer System, Washington, Oregon, and Idaho, subsets of which were used for analysis in this study

Figure 4. Diagram showing effect of commingling on water levels in hypothetical wells for aquifers of equal transmissivity

Figure 5. Diagram showing effect of commingling on water levels in hypothetical wells for aquifers of unequal transmissivity

Figure 6. Diagram showing effect of commingling on water levels in hypothetical wells for aquifers with local variability

Figure 7. Map showing distribution of wells used for status and trends analysis for the Columbia Plateau Regional Aquifer System, Washington, Oregon, and Idaho 16

Figure 8. Map showing distribution of groundwater-level trends in the Columbia Plateau Regional Aquifer System, Washington, Oregon, and Idaho, for 1968-2009 17

Figure 9. Map showing distribution of groundwater-level trends for 1968-2009 in Oregon Water Resources Department administrative areas in the Umatilla Basin, Oregon

Figure 10. Map showing groups of wells with similar hydraulic response near the Oregon Water Resources Department administrative areas in the Umatilla Basin, Oregon

Figure 11. Hydrographs showing groups of wells near the Oregon Water Resources Department administrative areas in the Umatilla Basin, Oregon

Figure 12. Graphs showing estimated stratigraphic position (distance from the well bottom to the simulated top of Grande Ronde Basalt) compared with winter median water-level elevation in selected wells within and immediately adjacent to the Oregon Water Resources Department administrative areas in the Umatilla Basin, Oregon, 1968, 1984, and 2006

Figure 13. Graph showing stratigraphic position (distance from the well bottom to the simulated top of Grande Ronde Basalt) compared with winter median water level measured in wells for shallow-deep well pairs from groups 3 and 14 near the Oregon Water Resources Department administrative areas in the Umatilla Basin, Oregon

Figure 14. Map showing distribution of groundwater-level trends for 1968-2009 relative to the Washington State Department of Ecology administrative areas in parts of the Palouse Slope/eastern Yakima Fold Belt and the Columbia Basin Ground Water Management Area, Washington....

Figure 15. Map showing generalized groundwater-flow paths under 2000-2010 conditions through sets of well groups with similar hydraulic response near the Washington State Department of Ecology administrative areas in parts of the Palouse Slope/eastern Yakima Fold Belt and the Columbia Basin Ground Water Management Area, Washington 


\section{Figures-Continued}

Figure 16. Hydrographs showing groups of wells corresponding to the western flow path near the Washington State Department of Ecology administrative areas in parts of the Palouse Slope/eastern Yakima Fold Belt and the Columbia Basin Ground Water Management Area, Washington

Figure 17. Hydrographs showing groups of wells corresponding to the eastern flow path near the Washington State Department of Ecology administrative areas in parts of the Palouse Slope/eastern Yakima Fold Belt and the Columbia Basin Ground Water Management Area, Washington

Figure 18. Hydrographs showing the middle groups of wells near the Washington State Department of Ecology administrative areas in parts of the Palouse Slope/eastern Yakima Fold Belt and the Columbia Basin Ground Water Management Area, Washington

Figure 19. Hydrographs showing groups of wells corresponding to the southern flow path near the Washington State Department of Ecology administrative areas in parts of the Palouse Slope/eastern Yakima Fold Belt and the Columbia Basin Ground Water Management Area, Washington

Figure 20. Graphs showing distance of the well bottom from the simulated top of Grande Ronde Basalt compared with water levels measured in wells near the Washington State Department of Ecology administrative areas in parts of the Palouse Slope/eastern Yakima Fold Belt and the Columbia Basin Ground Water Management Area, Washington

Figure 21. Map showing generalized potentiometric surface for measured Columbia River Basalt Group aquifer conditions during the pre-development period in parts of the Palouse Slope/eastern Yakima Fold Belt and the Columbia Basin Ground Water Management Area, Washington

Figure 22. Map showing generalized potentiometric surface for measured Columbia River Basalt Group aquifer conditions during 2000-2009 in parts of the Palouse Slope/eastern Yakima Fold Belt and the Columbia Basin Ground Water Management Area, Washington 


\section{Conversion Factors, Datums, and Abbreviations and Acronyms}

All conversion factors have been rounded to four significant digits. To reduce errors resulting from rounded conversion factors, reverse conversions should multiply by the inverse of the conversion factors originally used. For example, to convert feet into meters multiply by 0.3048 . To convert meters into feet multiply by $1 / 0.3048$.

Conversion Factors

Inch/Pound to SI

\begin{tabular}{|c|c|c|}
\hline Multiply & By & To obtain \\
\hline \multicolumn{3}{|c|}{ Length } \\
\hline inch (in.) & 2.54 & centimeter $(\mathrm{cm})$ \\
\hline inch (in.) & 25.4 & millimeter (mm) \\
\hline foot (ft) & 0.3048 & meter (m) \\
\hline mile (mi) & 1.609 & kilometer (km) \\
\hline \multicolumn{3}{|c|}{ Area } \\
\hline square mile $\left(\mathrm{mi}^{2}\right)$ & 259.0 & hectare (ha) \\
\hline square mile $\left(\mathrm{mi}^{2}\right)$ & 2.590 & square kilometer $\left(\mathrm{km}^{2}\right)$ \\
\hline \multicolumn{3}{|c|}{ Volume } \\
\hline acre-foot (acre-ft) & 1,233 & cubic meter $\left(\mathrm{m}^{3}\right)$ \\
\hline \multicolumn{3}{|c|}{ Flow rate } \\
\hline acre-foot per year (acre-ft/yr) & 1,233 & cubic meter per year $\left(\mathrm{m}^{3} / \mathrm{yr}\right)$ \\
\hline foot per day (ft/d) & 0.3048 & meter per day (m/d) \\
\hline foot per year (ft/yr) & 0.3048 & meter per year (m/yr) \\
\hline inch per year (in/yr) & 25.4 & millimeter per year (mm/yr) \\
\hline \multicolumn{3}{|c|}{ Hydraulic conductivity } \\
\hline foot per day (ft/d) & 0.3048 & meter per day (m/d) \\
\hline \multicolumn{3}{|l|}{ SI to Inch/Pound } \\
\hline Multiply & By & To obtain \\
\hline \multicolumn{3}{|c|}{ Length } \\
\hline meter (m) & 3.281 & foot (ft) \\
\hline
\end{tabular}




\section{Datums}

Vertical coordinate information is referenced to the North American Vertical Datum of 1988 (NAVD 88). Vertical coordinate information for historical data collected and stored as National Geodetic Vertical Datum of 1929 (NGVD 29) has been converted to NAVD 88 for this publication. Conversion between NAVD 88 and the commonly used NGVD 29 varies spatially; however, over most of the study area the following conversion can be used:

NGVD $29=$ NAVD $88-3.6$ feet.

This conversion generally is accurate within about \pm 0.5 feet for 95 percent of the study area. The reader is directed to either the National Geodetic Survey Web site for VERTCON at http:// www.ngs.noaa.gov/TOOLS/Vertcon/vertcon.html or the U.S. Army Corps of Engineers Web site for Corpscon at http://www.agc.army.mil/corpscon for more accurate conversions.

Horizontal coordinate information is referenced to the North American Datum of 1983 (NAD 83). Horizontal coordinate information for historical data collected and stored as North American Datum of 1927 (NAD 27) has been converted to NAD 83 for this publication. Conversion between NAD 83 and the commonly used NAD 27 varies spatially, and the difference in horizontal positions can be greater than 300 feet within the study area. For assistance with conversions, the reader is directed to either the National Geodetic Survey Web site for NADCON at http:// www.ngs.noaa.gov/TOOLS/Nadcon/Nadcon.html or the U.S. Army Corps of Engineers Web site for Corpscon at http://www.agc.army.mil/corpscon.

Elevation, as used in this report, refers to distance above the vertical datum.

Abbreviations and Acronyms

\begin{tabular}{ll}
$\begin{array}{c}\text { Abbreviation or } \\
\text { Acronym }\end{array}$ & \multicolumn{1}{c}{ Definition } \\
\hline CPRAS & Columbia Plateau Regional Aquifer System \\
CRBG & Columbia River Basalt Group \\
eYFB & eastern Yakima Fold Belt \\
GWMA & Columbia Basin Ground Water Management Area \\
MAF & million acre-feet \\
NWIS & National Water Information System \\
OWRD & Oregon Water Resources Department \\
SOWAT & SOil WATer balance model \\
USGS & U.S. Geological Survey \\
WADOE & Washington State Department of Ecology \\
\hline
\end{tabular}


viii

This page is intentionally blank. 


\title{
Ground water Status and Trends for the Columbia Plateau Regional Aquifer System, Washington, Oregon, and Idaho
}

\author{
By Erick R. Burns, Daniel T. Snyder, Jonathan V. Haynes, and Michael S. Waibel
}

\section{Abstract}

Well information and groundwater-level measurements for the Columbia Plateau Regional Aquifer System in Washington, Oregon, and Idaho, were compiled from data provided by the U.S. Geological Survey and seven other organizations. From the full set of about 60,000 wells and 450,000 water-level measurements a subset of 761 wells within the aquifers of the Columbia River Basalt Group (CRBG) then was used to develop a simple linear groundwater-level trend map for 1968-2009. The mean of the trends was a decline of 1.9 feet per year (ft/yr), with 72 percent of the water levels in wells declining. Rates of declines greater than $1.0 \mathrm{ft} / \mathrm{yr}$ were measured in 50 percent of wells, declines greater than $2.0 \mathrm{ft} / \mathrm{yr}$ in 38 percent of wells, declines greater than $4.0 \mathrm{ft} / \mathrm{yr}$ in 29 percent of wells, and declines greater than $8.0 \mathrm{ft} / \mathrm{yr}$ in 4 percent of wells.

Water-level data were used to identify groups of wells with similar hydraulic heads and temporal trends to delineate areas of overall similar groundwater conditions. Discontinuities in hydraulic head between well groups were used to help infer the presence of barriers to groundwater flow such as changes in lithology or the occurrence of folds and faults. In areas without flow barriers, dissimilarities in response of well groups over time resulted from the formation of groundwater mounds caused by recharge from irrigation or regions of decline caused by pumping. The areas of focus for this analysis included the Umatilla area, Oregon, and the Palouse Slope/eastern Yakima Fold Belt in the Columbia Basin Ground Water Management Area (GWMA) consisting of Adams, Franklin, Grant, and Lincoln Counties, Washington.

In the Umatilla area, water levels from 286 wells were used to identify multiple areas of high hydraulic gradient that indicate vertical and horizontal barriers to groundwater flow. These barriers divide the groundwater-flow system into several compartments with varying degrees of interconnection. Horizontal flow barriers commonly correspond to mapped geologic structure and result in horizontal hydraulic gradients that progressively become steeper from north to south corresponding to an increase in structural complexity that may be impeding recharge from the uplands into the heavily developed areas.
Most CRBG aquifers in the Umatilla area are declining and since 1970, cumulative declines range from about 100 to 300 feet. Significant vertical hydraulic gradients are documented for relatively small areas near Umatilla, and since the 1970s, downward vertical gradients in these areas have been increasing as hydraulic heads in the deeper units have declined. The absence of vertical gradients over much of the area may be a consequence of flow through commingling wells that results in the equilibration of the heads between aquifers.

On the Palouse Slope in the central GWMA, large groundwater declines occurred during 1968-2009 along a north-south swath in the middle of the region. An analysis of 1,195 wells along major flow paths and through the area of persistent groundwater-level declines indicates that barriers to flow are not as evident in this area as in Umatilla. This is consistent with the geologic interpretation of the Palouse Slope as being a gently folded structure created by voluminous sheet flows of CRBG lavas. Groundwater discharge into the sediment-filled coulees, where the upper aquifers are intersected at land surface by incised canyons, is proposed as an alternative to explain local steepening of the hydraulic gradient along the Palouse Slope previously attributed to the presence of a groundwater dam. Comparison of generalized potentiometric surface maps developed for pre-development conditions and post-2000 conditions indicate that pre-development groundwater flow was from the uplands toward the Columbia and Snake River and that post-2000 flow patterns in the area are controlled by irrigation practices that have resulted in broad regions of elevated or depressed hydraulic head. In some cases, irrigation-related changes in head have reversed groundwater flow directions. Evidence of significant vertical hydraulic gradients exists, although much of the aquifer thickness is affected by commingling of wells. The effect of commingling and its relative contribution to problems related to groundwater-level declines remains unclear. 


\section{Introduction}

The Columbia Plateau Regional Aquifer System (CPRAS) covers about $44,000 \mathrm{mi}^{2}$ of southeastern Washington, northeastern Oregon, and western Idaho (fig. 1). The population of the region is more than 1.3 million people (U.S. Census Bureau, 2000), and an important agricultural industry valued in the billions of dollars annually has developed despite the arid to semi-arid climate and limited access to surface-water resources. Groundwater availability in the aquifers of the area is a critical water-resource management issue because of the high demand of water for agriculture, economic development, and ecological needs. Groundwater levels have declined throughout much of the Columbia Plateau (Whiteman and others, 1994, p. B61-B65; Porcello and others, 2009; Burns and others, 2012). A comparison of water-level measurements from 1984 and 2009 from 470 wells in the CPRAS indicates that water levels declined in 83 percent of the wells and that declines were greater than $25 \mathrm{ft}$ in 29 percent of the wells (Snyder and Haynes, 2010).

The primary aquifers of the CPRAS are basalts of the Columbia River Basalt Group (CRBG) and in places, overlying basin-fill sediments. Water-resources issues that have implications for current and future groundwater availability in the region include (1) widespread waterlevel declines associated with development of groundwater for irrigation and other uses; (2) reduction in base flow to rivers and associated effects on water temperature, water quality, fish, and other aquatic organisms; and (3) current and anticipated effects of global climate change on recharge, base flow, demand, and ultimately, groundwater availability.

The U.S. Geological Survey (USGS) Groundwater Resources Program began a study of the CPRAS in 2007 with the broad goals of (1) characterizing the hydrologic status of the system, (2) identifying trends in groundwater storage and use, and (3) quantifying groundwater availability. The study approach includes updating the regional geologic and hydrogeologic frameworks, documenting changes in the hydrologic status of the system, quantifying the hydrologic budget, and developing a groundwater-flow model for the system. The model, which will be outlined in a separate report, will be used to evaluate and test the conceptual model of the groundwater flow within the system and to evaluate groundwater availability. This report, which describes the relation between groundwater levels and trends and hydrogeologic controls, along with four recently published reports (Kahle and others, 2009; Snyder and Haynes, 2010; Burns and others, 2011; Kahle and others, 2011), provides comprehensive information about the physical hydrogeologic framework of the CPRAS based on historical and current investigations. This study, in part, relied on data collection and analysis conducted as part of a cooperative agreement between the USGS and the Oregon Water Resources Department to better define the hydrologic conditions in the Umatilla basin of Oregon.

\section{Purpose and Scope}

The purpose of this report is to describe the compilation of groundwater-level data for the CPRAS that will be used for comparison with a numerical groundwater-flow model and to evaluate the status and trends in the data and their relation to hydrogeologic controls that influence the hydraulic properties of the aquifer or hydraulic stresses from recharge or pumping. The scope of this report includes a regional assessment of the importance of these controls described through the presentation of maps of groundwater elevations, water-level changes, stresses, and hydrogeologic features in the CPRAS. This information will help to develop a broad understanding of how climatic, anthropogenic, and hydrogeologic factors combine to influence groundwater flow, and how climate change and groundwater development may influence the sustainability and availability of the water supply in the region. The analyses presented in this report generally are restricted to the primary CRBG aquifers within the CPRAS to demonstrate important features in key areas, and do not seek to be an exhaustive analysis of any area. 


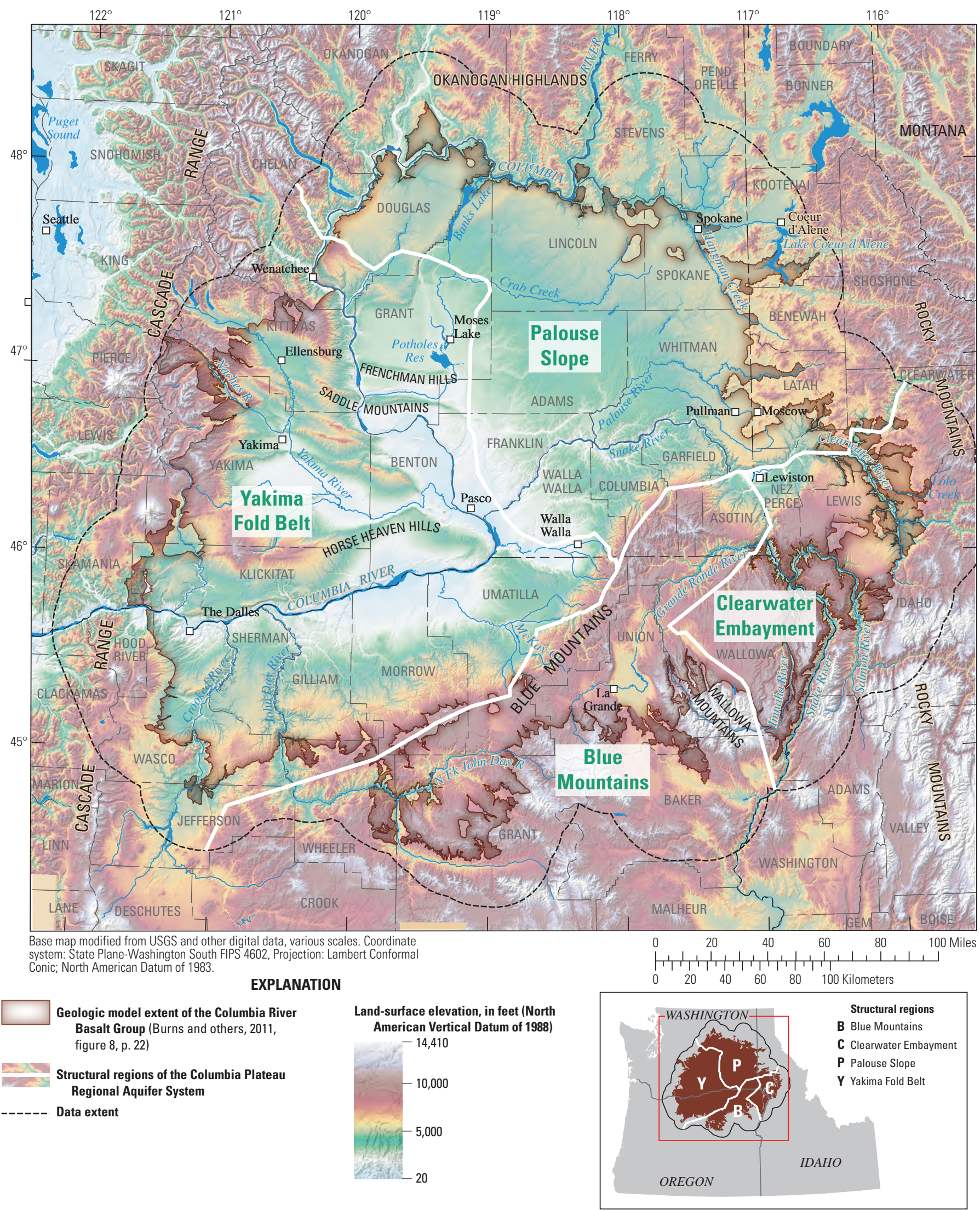

Figure 1. Location of Columbia Plateau Regional Aquifer System of Washington, Oregon, and Idaho. 


\section{Description of Study Area}

A complete description of the Columbia Plateau is available in Kahle and others (2011), parts of which are presented here. The Columbia Plateau (fig. 1) is a structural and topographic basin within the drainage of the Columbia River basin. It is bounded on the west by the Cascade Range, on the east by the Rocky Mountains, on the north by the Okanogan Highlands, and on the south by the Blue Mountains. The Columbia Plateau is underlain by massive basalt flows with thickness estimated to exceed $16,000 \mathrm{ft}$ near Pasco, Washington (Reidel and others, 2002, p. 211, fig. 2.6). Sedimentary deposits locally exceeding $2,000 \mathrm{ft}$ in thickness overlie the basalt over large areas of the plateau.

The Columbia Plateau was divided into four informal physiographic subprovinces that represent structural regions - the Yakima Fold Belt, Blue Mountains, Palouse Slope subprovinces, and the Clearwater Embayment (fig. 1). Groundwater characteristics in each of these regions can be different because of variations in stratigraphy, depositional environment, and post-deposition folding and faulting. The presence and importance of flow barriers in the CPRAS has been recognized and discussed in numerous studies (for example, Newcomb, 1959; Porcello and others, 2009). The Yakima Fold Belt includes most of the western half of the plateau and is characterized by a series of east-west trending anticlinal ridges and synclinal basins. The Palouse Slope occupies the northeast quarter of the plateau, is much less deformed, and has a gently southwestward dipping slope. The other structural regions within the CPRAS are the Blue Mountains, a composite anticlinal structure that forms the southeastern extent of the Columbia River basin, and the Clearwater Embayment, which marks the eastward extent of the CPRAS along the foothills of the Rocky Mountains and includes a series of folds extending into Idaho.
Much of the Columbia Plateau is semiarid, the mean annual precipitation for 1895-2007 (Kahle and others, 2011, p. 4) is about $17 \mathrm{in} / \mathrm{yr}$ (about 40 million acre-ft/yr) and ranges from about $7 \mathrm{in}$. in the center of the study area to more than $60 \mathrm{in}$. in the north-westernmost extent of the study area. The types and amounts of natural vegetation growing on the Columbia Plateau are largely dependent on precipitation and land-surface elevation. The vegetation ranges from sagebrush and grasslands at lower elevations to grasslands and forest at mid elevations to barren rock and conifer forests at the upper elevations. Dry land agriculture mainly includes winter and spring wheat and lentils. Irrigated agriculture includes apples, hops, and other crops.

Overviews of the geology and hydrology of the CPRAS presented summarize detailed descriptions in reports by (1) Kahle and others (2009), who discuss the geologic framework used in this report; (2) Burns and others (2011), who describe the three-dimensional characteristics of the geology of the CPRAS; and (3) Kahle and others (2011), who discuss the hydrogeologic framework and the hydrologic budget components of the CPRAS.

\section{Hydrogeologic Setting}

The Columbia Plateau is an intermontane basin between the Rocky Mountains and the Cascade Range that is filled with mostly Cenozoic basalt and sediment. Most rocks exposed in the region are the CRBG, intercalated sedimentary rocks, and overlying younger sedimentary rocks and deposits that include Pleistocene cataclysmic flood deposits, eolian deposits, and terrace gravels of modern rivers. The CRBG consists of a series of more than 300 flows that erupted in various stages during the Miocene, 17 million to 6 million years ago. Individual flows range in thickness from 10 to more than $300 \mathrm{ft}$ (Tolan and others, 1989; Drost and others, 1990). Soil and sediments that were formed or deposited on top of older lava flows and then covered and preserved by a subsequent lava flow are called sedimentary interbeds. 
Generalized geologic stratigraphy discussed in this investigation is broadly based on recognized formations within the Columbia River Basalt Group. The primary geologic formations of interest, listed in order of increasing age, include the Saddle Mountains Basalt, the Wanapum Basalt, and the Grande Ronde Basalt (fig. 2; Swanson and others, 1979, p. G4-G8; Whiteman and others, 1994, p. B32-B33). Younger sedimentary deposits cover parts of the CRBG across the study area and are referred to informally as the Overburden. The Overburden consists of undivided, unconsolidated to semi-consolidated sedimentary deposits ranging from Miocene to Holocene in age (Drost and others, 1990). These include many types of deposits of local and (or) regional extent including flood gravels and slack water sediments, terrace gravels of modern rivers, and eolian deposits that can range in thickness from 0 to 1,300 ft. The Saddle Mountains Basalt formation consists mostly of basalts and associated sedimentary interbeds and is the least extensive and youngest formation of the CRBG. Most of the formation is in the west-central part of the study area, with less continuous occurrences in the Blue Mountains and eastward into Idaho. Thickness of the Saddle Mountains Basalt ranges from 0 to about 1,000 ft. The Wanapum Basalt formation, composed mostly of basalt and sedimentary interbeds, is in the central part of the study area. Much of the formation lies beneath the Overburden and Saddle Mountains Basalt. Thickness of the Wanapum Basalt ranges from 0 to about 1,200 ft. The Grande Ronde Basalt formation is the oldest and most extensive of the basalt formations discussed and comprises the vast majority of the CRBG. This formation underlies most of the study area, except for an area along the southern boundary of the CPRAS in Oregon and along the eastern edge of the aquifer system in Idaho. The Grande Ronde Basalt formation contains basalt and sedimentary interbeds. Thickness of the formation is largely unknown, but may be greater than $15,000 \mathrm{ft}$ near the central part of the basin (Burns and others, 2011, p. 30, fig. 10D, and digital data).

Folding and faulting of the basalts occurred during the period of deposition and more recently. Younger basalt flows commonly were less-voluminous intra-canyon flows, so the distribution and thickness of these lavas are controlled by the shape of the valleys through which the lava flowed. Pleistocene outburst floods shaped the area by causing incision in the basalt, and erosion and deposition of the overlying sediment.

These geologic formations correspond to the hydrogeologic units defined for use in the USGS Regional Aquifer-System Analysis (RASA) Program and Groundwater Availability studies of the CPRAS (Whiteman and others,
1994, p. B32-B33; Kahle and others, 2009), and consist of the Overburden unit, the Saddle Mountains unit, the Wanapum unit, and the Grande Ronde unit. The informal term "unit" is used to differentiate from the formal geologic formations simplified for hydrologic discussions. For example, the geologic formations were simplified by grouping the Mabton and Vantage Interbeds into the Saddle Mountains and Wanapum units, respectively. The older rocks bordering and underling the CPRAS form the basement confining unit, referred to as the Older Bedrock hydrogeologic unit, and is composed of various rock types older than the CRBG, generally with much lower permeabilities than the basalts and considered the base of the regional flow system.

\section{Hydrogeologic Characteristics}

The hydraulic characteristics of the geologic materials determine how a groundwater-flow system functions and how it will respond to stresses such as pumpage. These characteristics include horizontal and vertical hydraulic conductivity and the storage coefficient. Because of the heterogeneity of the geologic materials that comprise the CPRAS, the hydraulic characteristics can vary considerably. The Overburden deposits are diverse in lithology and the large variation in grain size, depositional regimes, and age of the deposits account for the large range of their hydraulic characteristics (Kahle and others, 2011, p. 20). Each of the CRBG geologic units consist of tens to hundreds of individual layered basalt flows. The layers are highly variable in thickness and extent, but over much of the Columbia Plateau, the lava flows are comprised of flood basalts that form laterally extensive deposits. Hydraulic characteristics vary greatly within and between the individual basalt flows. Horizontal hydraulic conductivities generally are greatest in the interflow zones formed from the combination of basalt flow tops with the base of an overlying basalt flow, and an intervening sedimentary interbed, if present. Flow tops and bases commonly are brecciated, although they can exhibit a wide range of depositional textures. Because flow tops and bottoms commonly have open and highly-connected pore structures, the basalt interflow zones frequently exhibit high horizontal hydraulic conductivity (Lindolm and Vaccaro, 1988). The interflow zones are separated by the low hydraulic conductivity flow interior in which most fractures are cooling joints that often are vertically oriented (columnar jointing). Despite the fact that joints exist, flow interiors commonly are effective confining units. Porosity and permeability generally are lower in the older bedrock than in the Overburden and CRBG units. 


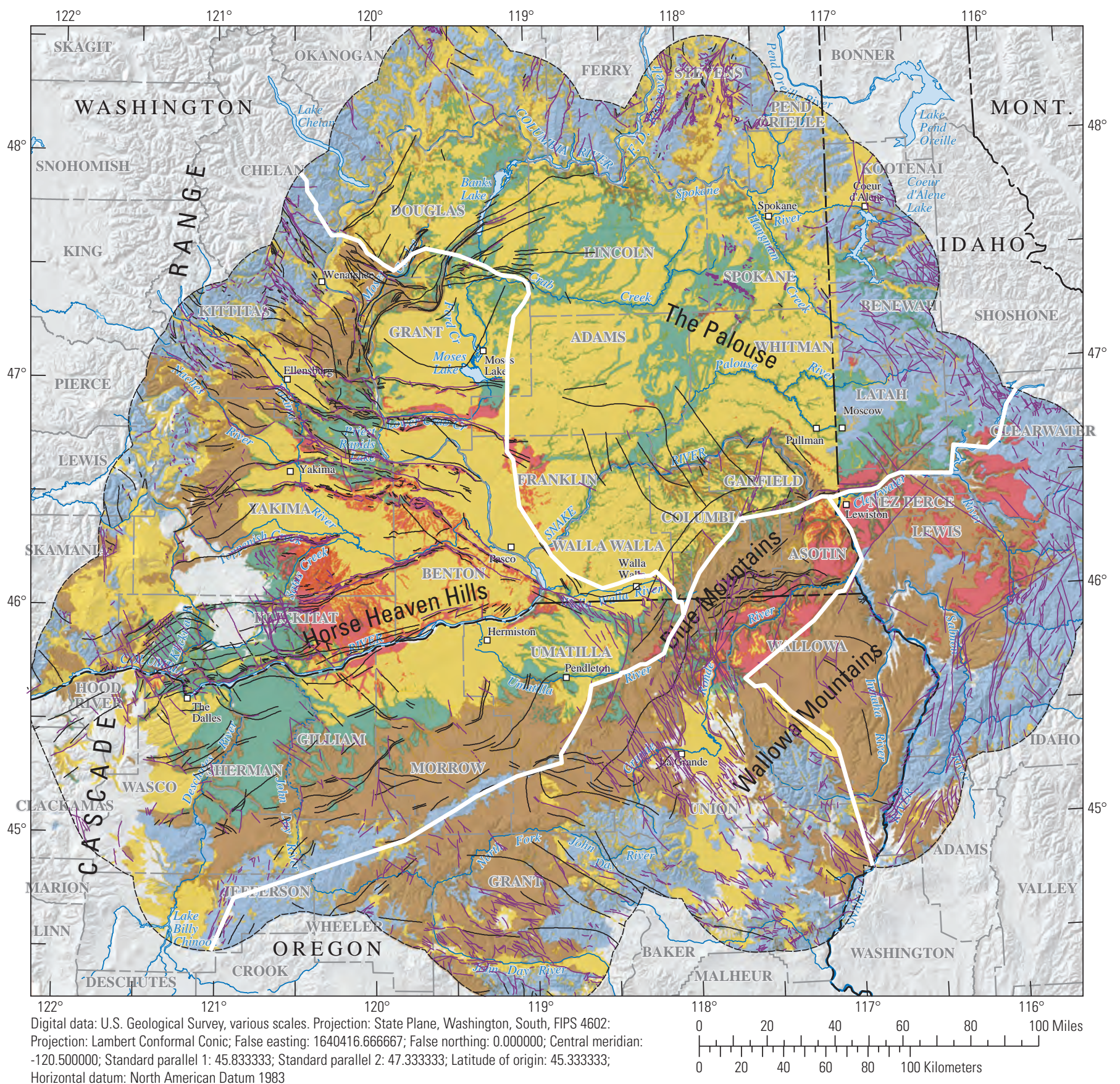

Horizontal datum: North American Datum 1983

\section{EXPLANATION}

$\begin{array}{ll}\text { Geologic units } & \text { Fault } \\ \text { Overburden (sedimentary) } & \text { Fold } \\ \text { Saddle Mountains Basalt } & \begin{array}{c}\text { Structural regions of the Columbia Plateau } \\ \text { Regional Aquifer System }\end{array} \\ \text { Wanapum Basalt } & \text { Data extent } \\ \text { Grande Ronde Basalt } & \\ \text { Older Bedrock } & \begin{array}{l}\text { Geologic data not used for modeling } \\ \text { (post-CRBG volcanics) }\end{array}\end{array}$

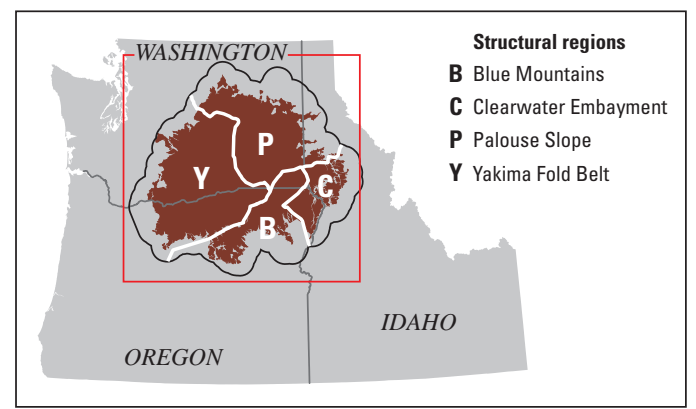

Figure 2. Surficial geology and structures of the Columbia Plateau Regional Aquifer System, Washington, Oregon, and Idaho. 
Kahle and others (2011, p. 21) estimated the median horizontal hydraulic conductivity values for the Overburden, basalt units, and older bedrock as 161, 70, and $6 \mathrm{ft} / \mathrm{d}$, respectively, based on specific capacity data reported in previous studies. Vertical hydraulic conductivity of the geologic units in the CPRAS generally is known to be low but is poorly quantified. Estimates of vertical hydraulic conductivity range from about 0.009 to $2 \mathrm{ft} / \mathrm{d}$ for the Overburden unit, although values for some parts of this unit may be as low as $10^{-10}$ to $10^{-7} \mathrm{ft} / \mathrm{d}$; values for the CRBG units range from $4 \times 10^{-7}$ to $4 \mathrm{ft} / \mathrm{d}$ (Kahle and others, 2011, p. 57).

The storage characteristics of an aquifer are described by the storage coefficient, a dimensionless property defined as the volume of water that an aquifer takes into or releases from storage per unit of surface area per unit change in head. Previous estimates of the storage coefficient in the CPRAS typically range from about 0.1 to 0.2 for the unconfined parts of the Overburden unit and from about 0.01 to $10^{-6}$ for the CRBG basalt units (Kahle and others, 2011, p. 26-27).

\section{Hydrologic Budget Components}

The following discussion and estimates of the regional-scale hydrologic budget components for the CPRAS is from the recent work by Kahle and others (2011). Mean annual recharge from infiltration of precipitation was estimated based on annual precipitation data and previous model simulation results of recharge. The estimates of the other budget components were developed using a monthly SOil WATer (SOWAT) balance model to determine irrigation water demand, groundwater flux to the underlying modeled soil zone (recharge or discharge), direct runoff, and soil moisture in irrigated areas (Kahle and others, 2011, p. 36). The SOWAT model was developed to make use of estimates of actual evapotranspiration available from a new Simplified Surface Energy Balance method that uses remotely sensed land-surface temperature data (Senay and others, 2007).

Mean annual recharge from the infiltration of precipitation of $4.6 \mathrm{in} / \mathrm{yr}$ (10.8 million acre-ft/yr) for 1985-2007 was estimated for the CPRAS. The spatial distribution in recharge mirrors that of annual precipitation, with the highest recharge (more than $20 \mathrm{in} / \mathrm{yr}$ ) occurring along the Cascade Range and the Blue Mountains. Mean annual recharge from infiltration of precipitation is less than $1 \mathrm{in} / \mathrm{yr}$ for a large part of the study area adjacent to the Columbia and Yakima Rivers where precipitation is limited.

Mean monthly irrigation throughout the study area peaks in July at 1.6 million acre-ft (MAF) (1985-2007 average), of which 0.45 and 1.15 MAF are from groundwater and surface-water sources, respectively. Annual use of irrigation water in the study area averaged 5.3 MAF during 1985-2007, with 1.4 MAF (or 26 percent) supplied from groundwater and 3.9 MAF supplied from surface water. Mean annual groundwater recharge from deep percolation of applied irrigation water in the study area was 4.2 MAF (1985-2007); 2.1 MAF (50 percent) occurred within the predominately surface-water irrigated regions of the Yakima Basin, Umatilla Basin, and Columbia Basin Project. The Columbia Basin Project, located in east central Washington, consists of more than $1,000 \mathrm{mi}^{2}$ of land irrigated with Columbia River water through a series of dams, pumping plants, and canals. Annual recharge rates range from less than $5 \mathrm{in} / \mathrm{yr}$ in predominately sprinkler-irrigated areas where groundwater is the source to more than $20 \mathrm{in} / \mathrm{yr}$ in surface-water supplied areas where conveyance losses and less-efficient application methods are more common.

Annual groundwater use (1984-2009) for purposes other than irrigation was estimated for the study area using information from several agencies. Public-supply groundwater use increased from about 201,000 acre-ft/yr in 1984 to about 269,000 acre-ft/yr in 2009. Domestic self-supplied groundwater use increased from about 54,600 acre-ft/yr in 1984 to about 71,200 acre-ft/yr in 2009. Industrial groundwater use decreased from about 53,400 acre-ft/yr in 1984 to about 43,900 acre-ft/yr in 2009. Other groundwater use, including for mining, thermoelectric needs, livestock, and aquaculture combined, increased from 16,900 acre-ft/yr in 1984 to about 43,600 acre-ft/yr in 2009.

\section{Groundwater Occurrence and Movement}

Groundwater moves through the regional aquifer system from the uplands to surface drainage features in the lowlands, mainly to the Columbia River and its major tributaries. Groundwater movement is affected by the geometry of the land surface and stream system, the extent, thickness, and hydraulic properties of the aquifers, the presence and nature of geologic structures, and the rate and location of groundwater recharge and discharge. Groundwater flow within the basalt units moves horizontally and vertically in the basalt interflow zones, flow centers, and sedimentary interbeds (Kahle and others, 2011, p. 27). Horizontal hydraulic conductivities generally are greatest in the interflow zones and consequently the interflow zones support most of the horizontal groundwater movement, whereas movement in the typically thick and lower horizontal hydraulic conductivity flow centers mainly is vertical. Therefore, the interflow zones in the basalt sequence form numerous, thin, semiconfined aquifers whose physical and hydraulic characteristics vary horizontally and vertically. Geologic complexity consisting of changes in lithology and folds and faults affect the geometry of flow paths by forming flow barriers or preferential pathways for groundwater flow (Snyder and Haynes, 2010, p. 7; Kahle and others, 2011, p. 27). 


\section{Study Methods}

Recent and historical water-level data were compiled from a large number of wells located throughout the CPRAS. These data were used to identify "well groups" each consisting of individual wells with similar hydraulic heads (groundwater levels) and temporal trends. Comparisons were made between adjacent well groups to delineate sets of well groups, which define areas of overall similar groundwater-flow conditions with regard to groundwater-flow directions and horizontal and vertical hydraulic gradients (the change in hydraulic head per unit of distance in a given direction). Discontinuities in groundwater-flow conditions between the sets of well groups were used to help infer the presence of features that contribute to control the regional flow of groundwater. These discontinuities can result from: (1) geologic features that influence the hydraulic properties of the aquifer such as changes in lithology or the occurrence of structural folds and faults, or (2) the presence of hydrologic features such as groundwater mounds or troughs caused by stresses such as recharge from irrigation or discharge to pumping.

\section{Sources of Data}

The evaluation of groundwater status and trends for the CPRAS relied on information that was routinely collected by many agencies or that was developed in the current or previous studies of groundwater availability in the CPRAS. In particular, this report relies heavily on the development of the geologic framework and three-dimensional geologic model by Kahle and others (2009) and Burns and others (2011), respectively, and the hydrologic budget components developed by Kahle and others (2011).

\section{Groundwater-Level Information}

The primary source of well information, including location, construction, and water-level measurements, was the USGS National Water Information System (NWIS). Additional well and water-level data were provided by the U.S. Department of Energy, Washington State Department of Ecology, Oregon Water Resources Department, Columbia Basin Ground Water Management Area, GSI Water Solutions, Inc., Confederated Tribes of the Umatilla Indian Reservation, and Walla Walla Basin Watershed Council. Due to constraints on project resources, not all wells or water-level measurements from the CPRAS were included in this study. Emphasis was placed on incorporating datasets with the greatest number of wells, which included information on well construction and many water-level measurements made over relatively long periods. Wells are primarily within the extent of the CPRAS, although some wells as much as $20 \mathrm{mi}$ outside of the CPRAS boundary also were included to help identify groundwaterlevel conditions across the boundary of the CPRAS (fig. 3). Information was acquired for 60,115 wells, although usable water-level data were available for only 39,610 wells. A total of 447,992 water-level measurements were collected from the 39,610 wells. The period of record for the water-level data extended from 1891 to 2010. The longest period of record for water-level measurements at an individual well is 96 years. Measurements at the longest annually monitored well began in 1940 and continue to the present (2011). From these data a subset of 7,772 wells and 147,563 water levels were used for the analyses presented in this report and are on file at the USGS office in Tacoma, Washington (http://wa.water.usgs. gov/projects/cpgw), and available upon request. Much of the data processing for analyzing groundwater levels was accomplished using Excel ${ }^{\circledR}$ spreadsheet tools developed by Tillman (2009).

Information on land-surface elevation was needed to calculate groundwater elevation from depth-to-water measurements. Land-surface elevations for many wells were reported by the agencies that provided the well information. Land-surface elevations were independently determined using a 10-m lateral resolution Digital Elevation Model (DEM; U.S. Geological Survey, 1999) as verification for these wells and to obtain land-surface elevations for the remaining wells with no reported values. Values of the DEM derived landsurface elevations were used if the difference between the reported and DEM derived elevations differed by greater than $100 \mathrm{ft}$. 


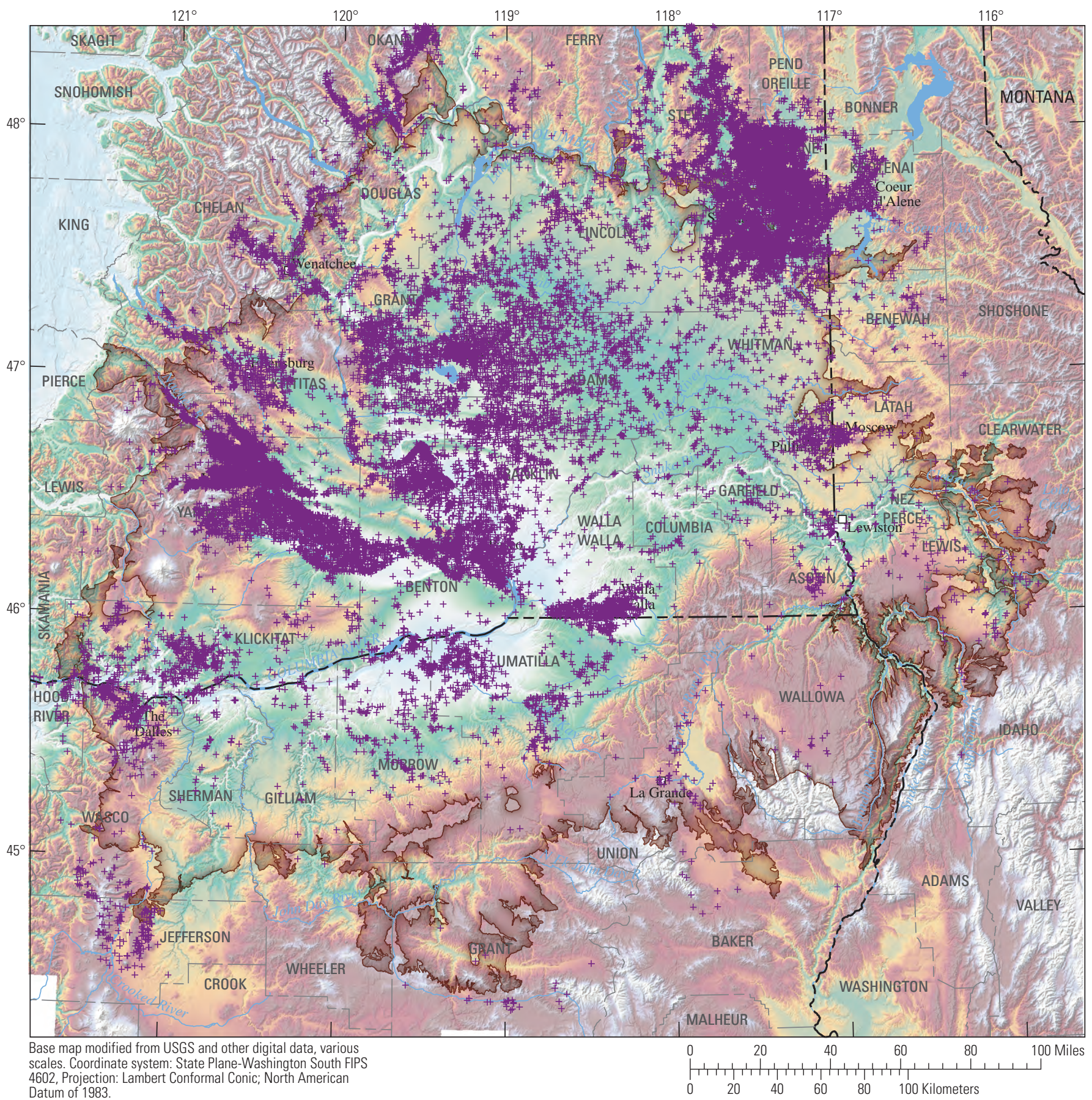

Datum of 1983.

\section{EXPLANATION}

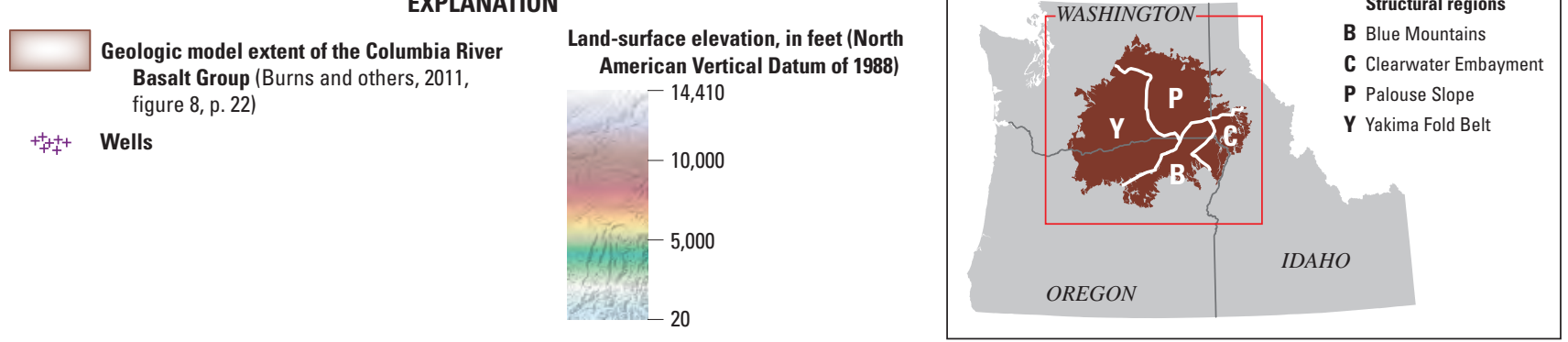

Figure 3. Locations of wells with usable water-level data within or immediately adjacent to the Columbia Plateau Regional Aquifer System, Washington, Oregon, and Idaho, subsets of which were used for analysis in this study. 


\section{Geologic Model}

A geologic model (Burns and others, 2011) provided improved estimates of CRBG and Overburden unit volumes and refined location of large structural features. This model was used to interpret the presence and significance of hydrogeologic controls on the groundwater system presented in this report. An on-line interactive tool was developed to serve point information and cross sections developed from the geologic model to the public (U.S. Geological Survey, 2012).

\section{Data Limitations}

The accuracy and representativeness of the groundwater-level measurements are dependent on various factors pertaining to measurement accuracy, quality assurance procedures, local conditions in the aquifer at the time of measurement, and well construction.

\section{Measurement Accuracy and Data Compilation}

Typical methods used to measure the depth to water in a well have precisions ranging from $0.01 \mathrm{ft}$ to several feet. The precision of most measurements is expected to be in the range of about $0.1 \mathrm{ft}$. However, the accuracy of the determination of the groundwater elevation (how it compares to the actual value) depends on how the depth to water measurement is transformed to a groundwater elevation at a particular location, how it is associated with a particular aquifer, and the associated quality assurance procedures. A major factor affecting measurement accuracy is related to how the elevation for the well was determined, and the errors associated with assigning an elevation to the well. Errors also can relate to the location of the well. Errors in the latitude and longitude coordinates for the site can create errors of hundreds of feet in the assigned elevation of the water level, especially in areas with steep relief. For this report, well locations and elevations were mostly based on information reported from the respective agencies. A comparison was made between reported well elevations and those determined from a 10-m DEM on the basis of the reported latitude and longitude locations and lateral datums from the respective agencies. The median of the absolute values of the elevation differences is $4.3 \mathrm{ft}$ and 90 percent of the differences are less than $44 \mathrm{ft}$.

The well and water-level data were compiled from many different agencies. Each agency has its own protocols for the description and documentation of measured wells, for the collection and recording of water-level data, and quality assurance procedures. Errors can occur when compiling large datasets due to either data entry, arithmetic errors, or treatment of exceptions when using rule-based algorithms to write all data into a common database. Common errors include incorrect well identification or location, incorrect or incomplete well construction information, errors in depth to water measurements, and incorrect determination of land-surface elevations. Additionally, some well information and water-level measurements for the same well may be reported by multiple agencies resulting in duplication of information. An effort was made to identify and correct errors in the data used in this study. However, it was not possible to ascertain the quality of the well information or water-level measurement for each well and undoubtedly, errors are present in the data. The large number of wells and measurements used in the analyses in this study should help to minimize the influence of these errors and provide a robust estimate of the groundwater elevation.

Water-level measurements in reports filed by well drillers at the time of new well installations were included in the compilation of water levels. However, measurements of water levels in newly constructed wells may not have been at equilibrium at the time of measurement and therefore may not represent static water-level conditions (Snyder, 2008, p. 11-14). Water-levels where the status indicated the well was dry, obstructed, or influenced by pumping, were excluded from the analyses as these water levels may not represent static conditions.

\section{Representative Sampling}

The groundwater-level measurements used in this study are assumed to be representative of the groundwater positions within the aquifers of the CPRAS. However, some of the data may suffer from a number of possible biases. These biases may arise from a variety of sources such as influences due to localized conditions and stresses, well construction, and commingling of groundwater. In addition, the spatial distribution and selection of wells used for the collection of water-level measurements may be biased as a result of increased scrutiny and monitoring in areas with groundwater declines. This can result in the clustering of wells and an over-representation of wells showing water-level declines. 


\section{Localized Conditions and Stresses}

Pumping and recharge stresses can cause geographically localized or transient perturbations of water levels. Water-level measurements affected by such localized perturbations may not be representative of true conditions in the aquifer over a broader area.

Recharge in the CPRAS is dominated by precipitation (Kahle and others, 2011), which generally has gradual geographic variation. However, other recharge sources such as irrigation water, artificial recharge, or leakage from streams, canals, or lakes can influence groundwater levels over short distances. Stresses due to discharge by pumping, or to gaining streams, springs, seepage faces, wetlands, or evapotranspiration similarly can have large variations over short distances and influence groundwater levels.

The aquifer properties that influence the movement and storage of water in the aquifer and, therefore the groundwater level in the aquifer, include the extent, thickness, shape, hydraulic conductivity, storage coefficient, and degree of confinement. These properties can be highly heterogeneous over short distances due to variations in the original lithology or process of emplacement, subsequent modification by physical process such as erosion or fracturing due to structural deformation, or chemical changes such as dissolution, alteration, or mineralization. Variations in these properties over short distances may affect the groundwater levels and (or) the timing and magnitude of groundwater changes in response to changes in stresses relative to groundwater levels elsewhere in the aquifer.

\section{Influence of Well Construction}

Well construction may substantially influence the water levels in wells. Ideally, a well used for groundwater-level monitoring should be constructed to ensure good hydraulic connection between the well and the intended aquifer and that the water level and water-level fluctuations in the well broadly represent conditions in the aquifer. The well design must take into consideration the placement of open intervals and include appropriately-sized well screens to permit a good hydraulic connection between water in the aquifer and in the well. The use of sanitary and flow seals and well casings, where needed, help to isolate the well and the contributing aquifer from other units to prevent commingling, the collapse of rock into the well, and movement of water between the rock and the outside of the well casing. Incorrect well design, construction defects at the time of installation, insufficient well development (repeated purging and filling of a well to remove fine materials that may clog the well screen), or degradation due to age including silting, corrosion, or bacterial growth may affect how a well responds to changes in the aquifer (Taylor and Alley, 2002, p. 9).

Complete and accurate documentation of the well construction is important to ensure that the water levels measured in the well are properly interpreted. Documentation of well construction for some wells often is incomplete and does not include sufficient information, such as lithology or position of open intervals, to identify the contributing aquifer(s). This creates uncertainty on how to associate a water-level measurement from a well with the appropriate aquifer. Uncertainty with regard to the aquifer represented in a water-level measurement can contribute to misleading interpretations.

Over time, water-level declines in the CPRAS have resulted in dry wells, some of which have been deepened and reconstructed. Because water-levels from a deepened or reconstructed well represent conditions at a different location in the aquifer system, measurements always should be associated with well depth and construction at the time of measurement. However, in most instances the information on the deepening of wells was not associated with the original well for the data compilation sources used for analysis in this study. As a result, water-level measurements made subsequent to the deepening of some wells may remain associated with the depth of the original well. Hydrographs for these wells may show an initial step change in the water-levels measured in the well following deepening that could be mistakenly attributed to other causes. The water-level response of the well subsequent to deepening also may reflect the conditions in the aquifer at the new well depth. To address these limitations, robust methods of analysis were used to ensure that errors at individual wells did not strongly affect overall study conclusions. 


\section{Commingling}

Commingling is the term used to describe the condition that occurs when a well is constructed so water can move from one aquifer to another through the well bore. This can occur in wells that are open to multiple aquifers through screens or uncased intervals. If the aquifers have different heads, then water will move through the well bore from the aquifer(s) with higher head to the aquifer(s) with lower head. When such commingling occurs, the static water level in the well is a composite water level, averaging conditions between all the aquifers open to the well.
In figure 4, well 3 is a hypothetical multiple completion well with open intervals in aquifers 1 and 2, which results in commingling of waters between aquifers. Because the hydraulic head in aquifer 1 (as represented by the potentiometric surface of the aquifer at the well) is greater than the hydraulic head in aquifer 2 a downward hydraulic gradient enables flow to enter the well 3 bore from aquifer 1, traversing down the well 3 bore and exiting the well 3 bore into aquifer 2. For this example, the transmissivities of aquifer 1 and 2 are equal; therefore, the resulting hydraulic head in well 3 , from a transmissivity-weighted average of the heads

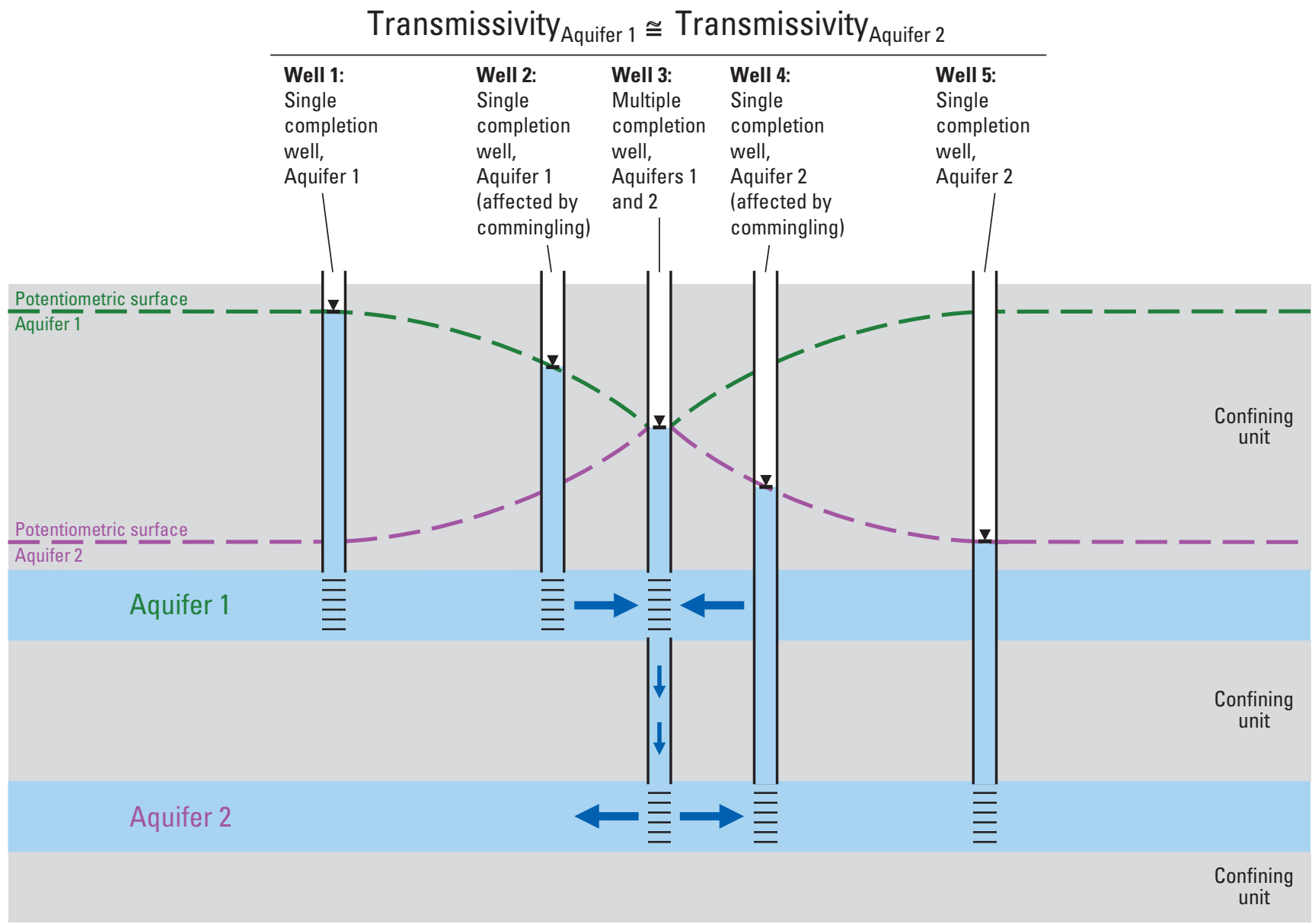

Figure 4. Effect of commingling on water levels in hypothetical wells for aquifers of equal transmissivity. Near the commingled well (well 3), the potentiometric surface is strongly affected by aquifer cross-connection. Far from the commingled well, the potentiometric surface reflects regional conditions. 
in aquifers 1 and 2, is exactly one-half the vertical distance between the head in the two aquifers. Well 2 and well 4 are single completion wells with open intervals within aquifer 1 and aquifer 2 , respectively, that are in close proximity to commingling well 3 . These wells are within the cone of depression and cone of impression (the inverse of a cone of depression) resulting from the commingling in well 3 . The hydraulic head in these wells is intermediate to the head at well 3 and the initial unaffected heads in aquifers 1 and 2 as represented by the heads in wells 1 and 5, respectively.
In figure 5, the transmissivity of aquifer 1 is much greater than the transmissivity of aquifer 2; therefore, the head in well 3 is dominated by the hydraulic head of aquifer 1 . Because the cone of depression for aquifer 1 is greatly subdued, water levels in proximal wells open to aquifer 1 , such as well 2 , are minimally affected. However, water levels in proximal wells open to aquifer 2 , such as well 4 , are strongly affected due to the exaggerated cone of impression for aquifer 2 .

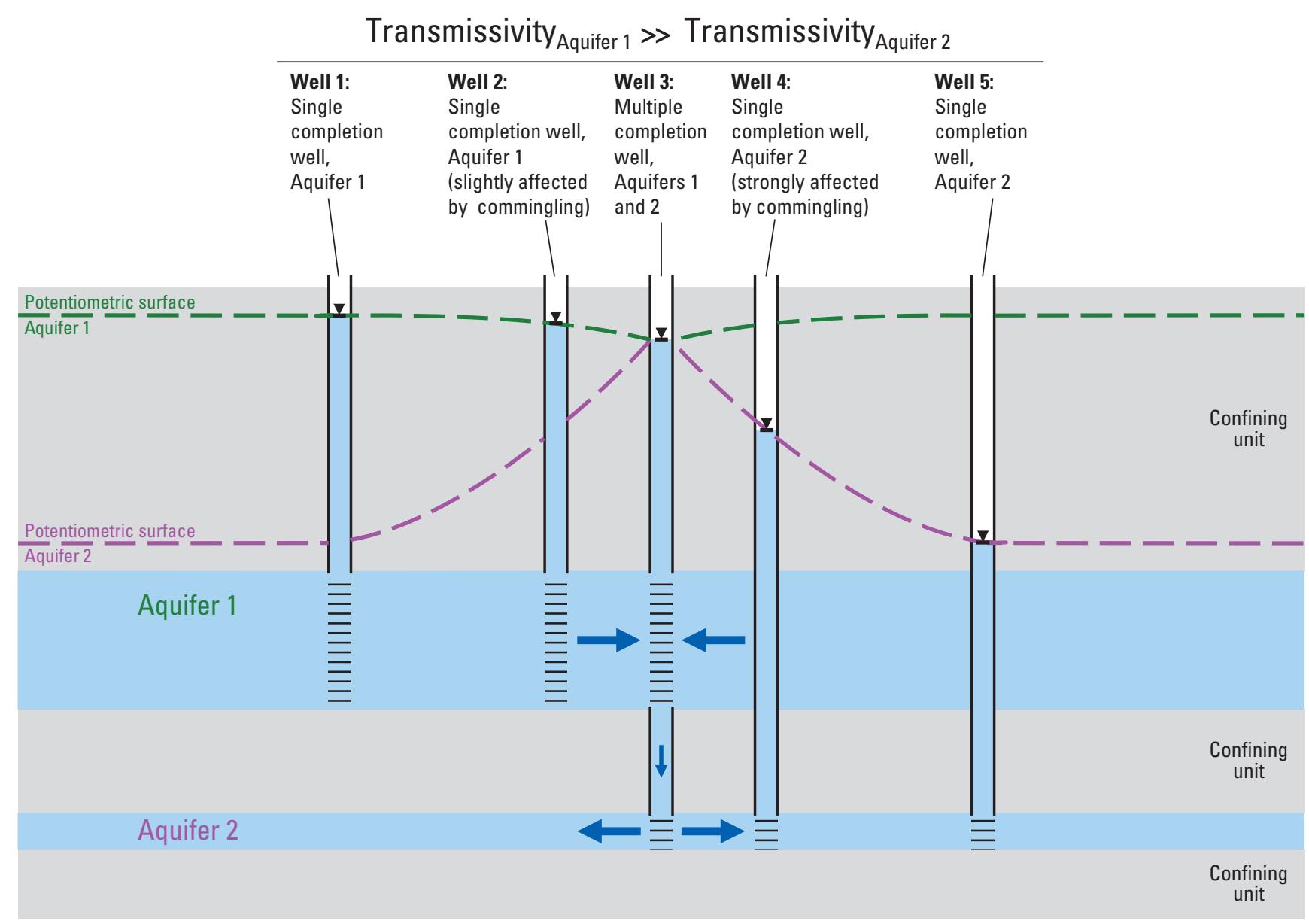

Figure 5. Effect of commingling on water levels in hypothetical wells for aquifers of unequal transmissivity. Water level in a well most closely resembles the aquifer with the higher transmissivity because the well has better hydraulic connection to this aquifer. Near the commingled well (well 3), the potentiometric surface is strongly affected by aquifer cross-connection. Far from the commingled well, the potentiometric surface reflects regional conditions. 
The basalt aquifers of the CPRAS consist of a series of permeable interflow zones separated by less permeable flow interiors (Kahle and others, 2011, p. 20). The transmissivities of the aquifers can vary over several orders of magnitude (Kahle and others, 2011). The resulting water levels in commingled wells open to multiple aquifers depend on the relative transmissivity of the aquifers, which is a function of the thickness and the permeability of the aquifers. Figure 6 illustrates some possible examples for aquifers of varying transmissivity (thickness and (or) permeability).
The ratio of water-level fluctuations in a well to the groundwater-level fluctuations in an aquifer penetrated by that well is equal to the ratio of transmissivity of the aquifer in which the fluctuation occurs to the total transmissivities of all aquifers perforated by the well. As a result, the effect of the change in groundwater level of any aquifer where the well is open imposes a smaller change on the water level in the well (Sokol, 1963, p. 1,080).

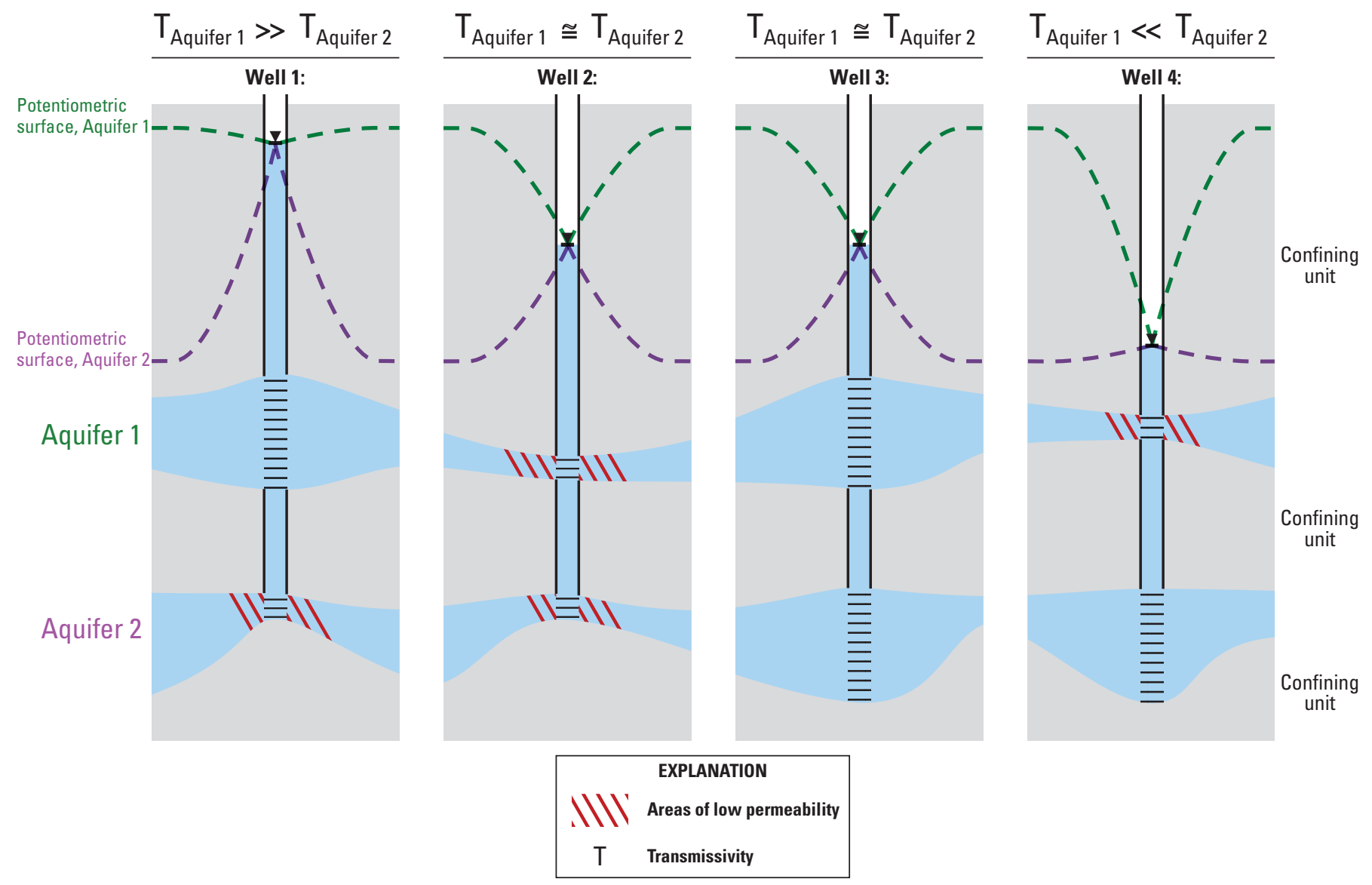

Figure 6. Effect of commingling on water levels in hypothetical wells for aquifers with local variability. Water level in a well most closely resembles the aquifer with which it is in best connection. The flow of water can be restricted by changes in aquifer thickness, aquifer lithology, or well construction, resulting in reduced hydraulic connection. Near a commingled well, the potentiometric surface is strongly affected by aquifer cross-connection. Far from the commingled well, the potentiometric surface reflects regional conditions. 


\section{Groundwater Status and Trends}

Trend analyses were done on the compiled groundwaterlevel data for the CRBG aquifers to characterize and document changes in the hydrologic status of the system. Water levels in individual wells vary in response to natural and anthropogenic stresses on daily, seasonal, decadal, and longer time scales. Because the purpose of the USGS Groundwater Resources Program study is to evaluate the long-term availability and sustainability of groundwater resources within the CPRAS, the focus of the data analysis is to examine persistent decadal or longer trends that have occurred in many wells since the onset of widespread irrigation and groundwater pumping.

For the trend analysis, groundwater measurements representing conditions within the CRBG aquifers were used. The geologic model of Burns and others (2011) was used to identify wells with bottom elevations between the simulated top of the CRBG geologic units and the older pre-Miocene basement rocks. Water-level measurements from these identified wells then were used in the analyses. To remove daily and seasonal variation in groundwater levels induced by irrigation pumping, the median groundwater level measured in winter between January and March of each year was used in the analysis. The resulting data reflect the influence of multi-year precipitation patterns and the cumulative effects of pumping and irrigation recharge.

Water-level measurements made prior to 1951 are assumed to represent pre-development conditions because large scale irrigation started after the beginning of 1951. Because summer water levels in wells were not yet affected by large scale groundwater pumping, annual median water levels were used when winter water-level data were not available prior to 1951.

Water-level measurements in reports filed by well drillers at the time of new well installation were included to obtain the broadest spatial and temporal distribution possible in areas or periods of sparse data. Groundwater-level measurements reported as non-static measurements were excluded from analysis. The subsampled dataset includes 7,735 CRBG wells, with data representing pre-development conditions in 1,265 wells (fig. 7).

Although pumping and irrigation effects began to have appreciable effects on groundwater levels during the 1950s in the CPRAS, most persistent regional declines from pumping started after 1970. A map of the linear trends in groundwater levels for 1968-2009 was constructed to show areas of widespread declines in CRBG aquifers (fig. 8). Groundwater-level trends were computed as the slope of the best-fit line to the winter median water-level data for each well, provided that at least four data points were available that spanned at least 50 percent of the period 1968-2009. Of the 761 wells in the CRBG aquifers with sufficient data to compute water-level trends, overall declines were measured in 72 percent of the wells. The mean of the slopes of the waterlevel trends for all wells was a decline of $1.9 \mathrm{ft} / \mathrm{yr}$. Rates of declines greater than $1.0 \mathrm{ft} / \mathrm{yr}$ were measured in 50 percent of wells, declines greater than $2.0 \mathrm{ft} / \mathrm{yr}$ in 38 percent of wells, declines greater than $4.0 \mathrm{ft} / \mathrm{yr}$ in 29 percent of wells, declines greater than $6.0 \mathrm{ft} / \mathrm{yr}$ in 9 percent of wells, and rates of decline greater than $8.0 \mathrm{ft} / \mathrm{yr}$ in 4 percent of wells. These results are similar to the values obtained by Snyder and Haynes (2010, table 1, p. 8) for 273 CRBG aquifer wells in the CPRAS during 1984-2009 where water levels declined in 81 percent of wells and water levels changed at an average rate of a $1.5 \mathrm{ft} / \mathrm{yr}$ decline (calculated as a weighted-mean average for all CRBG aquifer wells). Because complex anomalous behavior can occur for any single well hydrograph (for example, step changes in water level associated with nearby well construction activities), the linear water-level trend for any single well may not represent conditions over an area of interest, but the general pattern of water-level declines in multiple wells illustrates the persistent patterns across the CPRAS.

The clusters of wells with linear declines generally correspond to areas that are the subject of previous hydrogeologic studies and to continued data collection efforts by local, State, Federal, or non-governmental agencies in Oregon in the Mosier Watershed and Umatilla Basin, and in Washington in the Yakima Basin and the Palouse Slope/ eastern Yakima Fold Belt in the Columbia Basin Ground Water Management Area (GWMA). The Columbia Basin GWMA, which encompasses Adams, Franklin, Grant, and Lincoln Counties (fig. 8), was designated by the Washington State Department of Ecology (WADOE), for the protection of groundwater in the area. Detailed analyses of well hydrographs for the Mosier Watershed, Oregon, and Yakima Basin, Washington, are available in Burns and others (2012) and Keys and others (2008), respectively. Well hydrographs are examined for parts of the Umatilla Basin, Oregon, and the Palouse Slope/eastern Yakima Fold Belt (within the GWMA), Washington, in this report. Groundwater-level hydrographs for the Umatilla Basin show that barriers to groundwater flow are readily identifiable. Conversely, groundwater-level hydrographs from the Columbia Basin GWMA exhibit a significantly different behavior, with fewer well-defined barriers to flow and with groundwater-level changes being dominated by the large-scale irrigation projects in the lowland near the Columbia River. An analysis describing the relation between well hydrographs and geologic features in the GWMA is presented by Porcello and others (2009); therefore, the discussion here is restricted to a complementary discussion of regional-scale flow patterns and hydraulic changes resulting from development of water resources in the GWMA since 1950. 


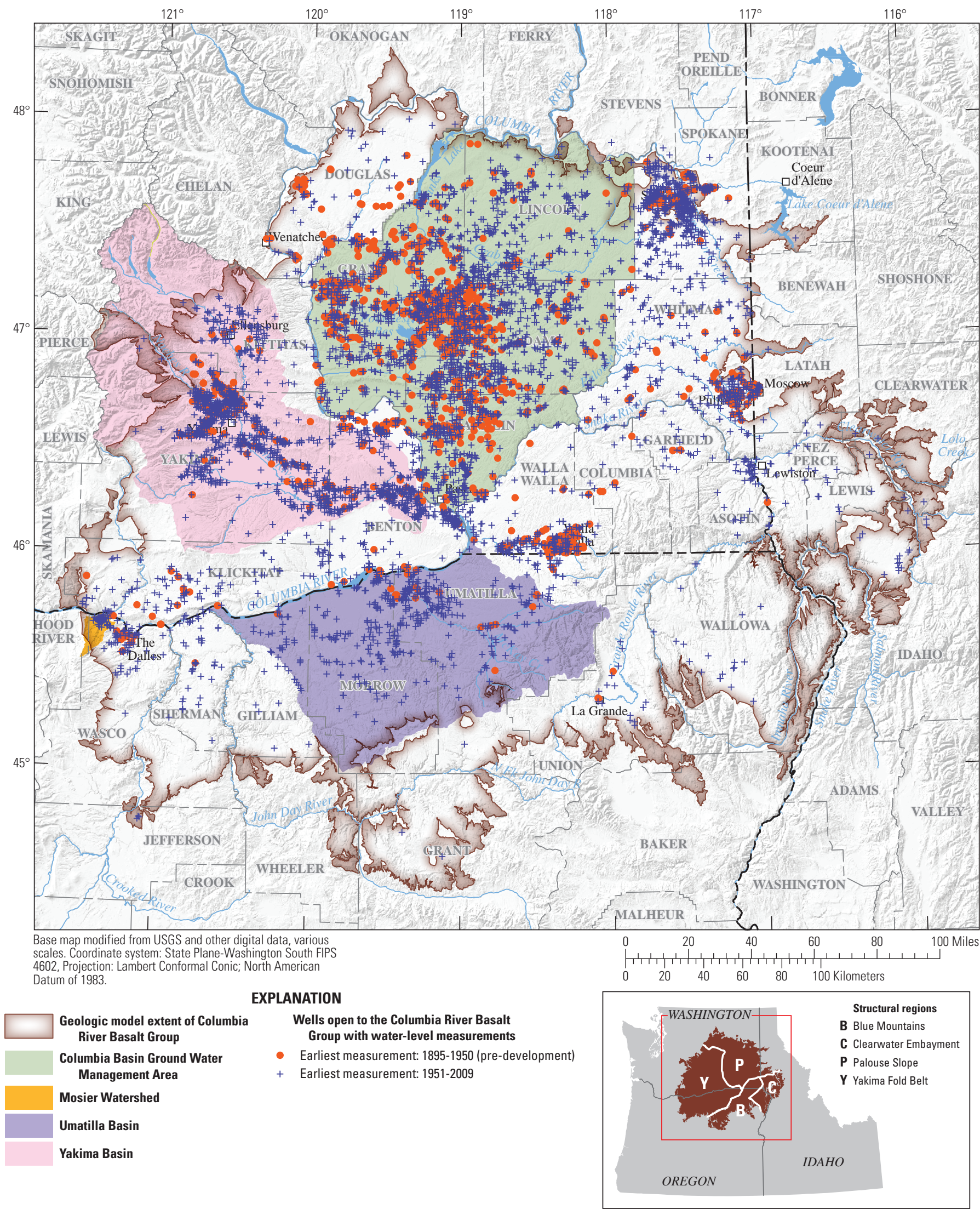

Figure 7. Distribution of wells used for status and trends analysis for the Columbia Plateau Regional Aquifer System, Washington, Oregon, and Idaho. The water levels represent the period each year when seasonal pumping effects are minimal. 


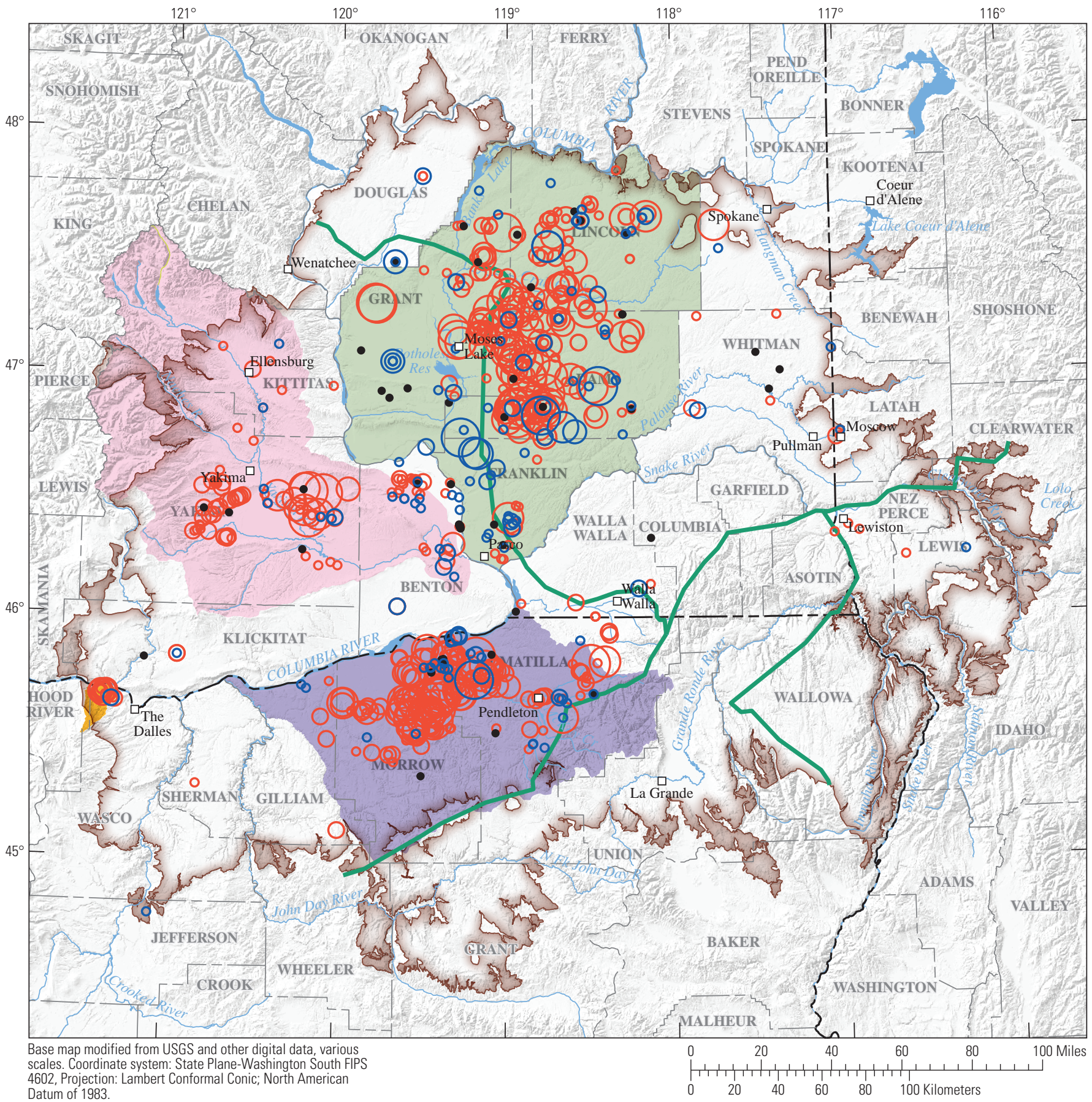
Datum of 1983.

EXPLANATION

\begin{tabular}{|l|l|}
\hline Modeled extent of Columbia River Basalt Group \\
Columbia Basin Ground Water Management Area \\
\hline Mosier Watershed \\
\hline Umatilla Basin \\
Yakima Basin \\
\hline Structural regions of the Columbia Plateau \\
Regional Aquifer System (see inset map)
\end{tabular}

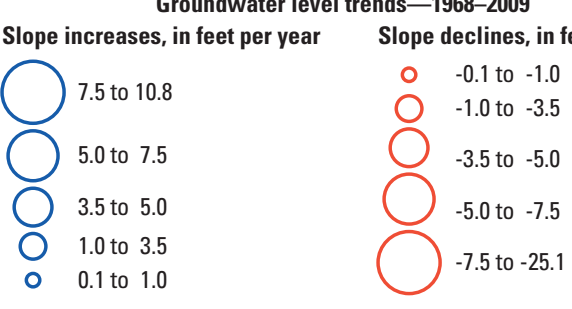

- Slope, flat -0.1 to 0.1

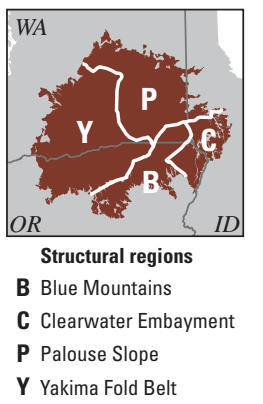

Figure 8. Distribution of groundwater-level trends in the Columbia Plateau Regional Aquifer System, Washington, Oregon, and Idaho, for 1968-2009. 


\section{Umatilla Area, Oregon}

The Oregon Water Resources Department (OWRD) established several administrative areas (Critical Ground Water Areas and Ground Water Limited Areas) in the area of the Umatilla Basin that cover most locations with large long-term groundwater declines. Administrative areas include Butter Creek, Ella Butte, Ordnance Basalt, and Stage Gulch (fig. 9; Oregon Water Resources Department, 2012). A total of 286 wells within and immediately adjacent to the OWRD administrative areas in the CRBG aquifers were divided into clustered groups of wells with similar water levels and trends (fig. 10). Figure 11 presents hydrographs showing the winter median water levels for individual wells within each well group shown in figure 10 and a trend line representing the overall water-level trend of all wells in the group constructed using the LOESS algorithm in the statistical software program TIBCO Spotfire S+ (TIBCO Software, Inc., 1988-2008). Zones of low permeability may separate the groups of wells with similar groundwater levels and trends. These zones represent leaky barriers to groundwater flow and compartmentalize the CRBG aquifer system. The degree of compartmentalization is variable, but it occurs in both the vertical and horizontal directions in the Umatilla area.

Horizontal flow barriers (barriers prohibiting or reducing horizontal groundwater flow) were identified between adjacent well groups when water levels and trends were different for wells open to the same aquifer. Because aquifers have not been mapped extensively within the study area, drilling of each well was presumed stopped when the target aquifer was found. The elevation where drilling stopped was used as an estimate of the elevation of an aquifer at that location. However, the originally flat-lying CRBG lava flows have been deformed over geologic time, so the CRBG interflow zones hosting most productive aquifers in the CPRAS are not horizontal. To correct for the departure from horizontality, the geologic model of Burns and others (2011) was used to compute estimates of the stratigraphic positions for water producing zones in each well. Correction was accomplished by subtracting the estimated top elevation of the Grande Ronde Basalt geologic model unit from each well bottom elevation. Positive values indicate aquifers are in the lavas above the top of the Grande Ronde Basalt, and negative values indicate aquifers are in the Grande Ronde Basalt. Plotting the groundwater level against this stratigraphic position for each well allows a rapid assessment of whether or not hydraulic head values are representative of the same aquifers (fig. 12). However, the flow margin of several younger (post Grande Ronde Basalt) lava flows are within the area of interest with thicker deposits to the north. The resulting wedge shape of the overlying lavas complicates the interpretation of positive elevations (fig. 12) corresponding to aquifer horizons, especially for north-south transects. Additional details regarding this method are provided in appendix A.

An example of strong horizontal compartmentalization is provided by comparing groups 2 (dark blue triangles) and 12 (gray triangles) (fig. 10). Measurements for these two groups likely are from the same aquifer within the Grande Ronde Basalt although water levels differ on average by about $500 \mathrm{ft}$ (figs. 11B and 12D-F). Within each group, water levels for nearby wells commonly are within a few tens of feet of each other. Group 2 wells have a wider range of values than group 12 wells, which corresponds to a relatively smooth hydraulic gradient from Pendleton, Oregon, to the center of the Stage Gulch administrative area.

An example of a vertical flow barrier is provided by groups 3 (dark green squares) and 14 (light blue squares) (fig. 10). In map view, these groups apparently occupy much of the same area; therefore, horizontal compartmentalization does not explain the hydraulic head contrast between the groups that began in the 1960s (fig. 11A). However, based on the shallow and deep well pairs shown in figure 10, group 3 well bottoms are consistently above group 14 well bottoms (fig. 13), indicating that the aquifers are separated vertically, with the shallow group 3 wells exhibiting no persistent water-level declines, and the deeper group 14 wells exhibiting substantial declines since the 1960s. Whereas small groups of wells show ideal vertical separation (fig. 13), the pattern is obscured when considering all wells in groups 3 and 14 at the same time (fig. 12A- ). Well bottoms for group 3 wells trend to lower elevations of stratigraphic position to the south (not shown), indicating that the group 3 aquifer(s) are sloping relative to the estimated top of Grande Ronde Basalt consistent with the thickening of the younger lavas to the north. If aquifers were mapped based on similarity in hydraulic head, the apparent overlap of groups 3 and 14 (fig. 12) would disappear and the ideal vertical separation (compare fig. 13 with appendix A, fig. A1A) would be more apparent. 


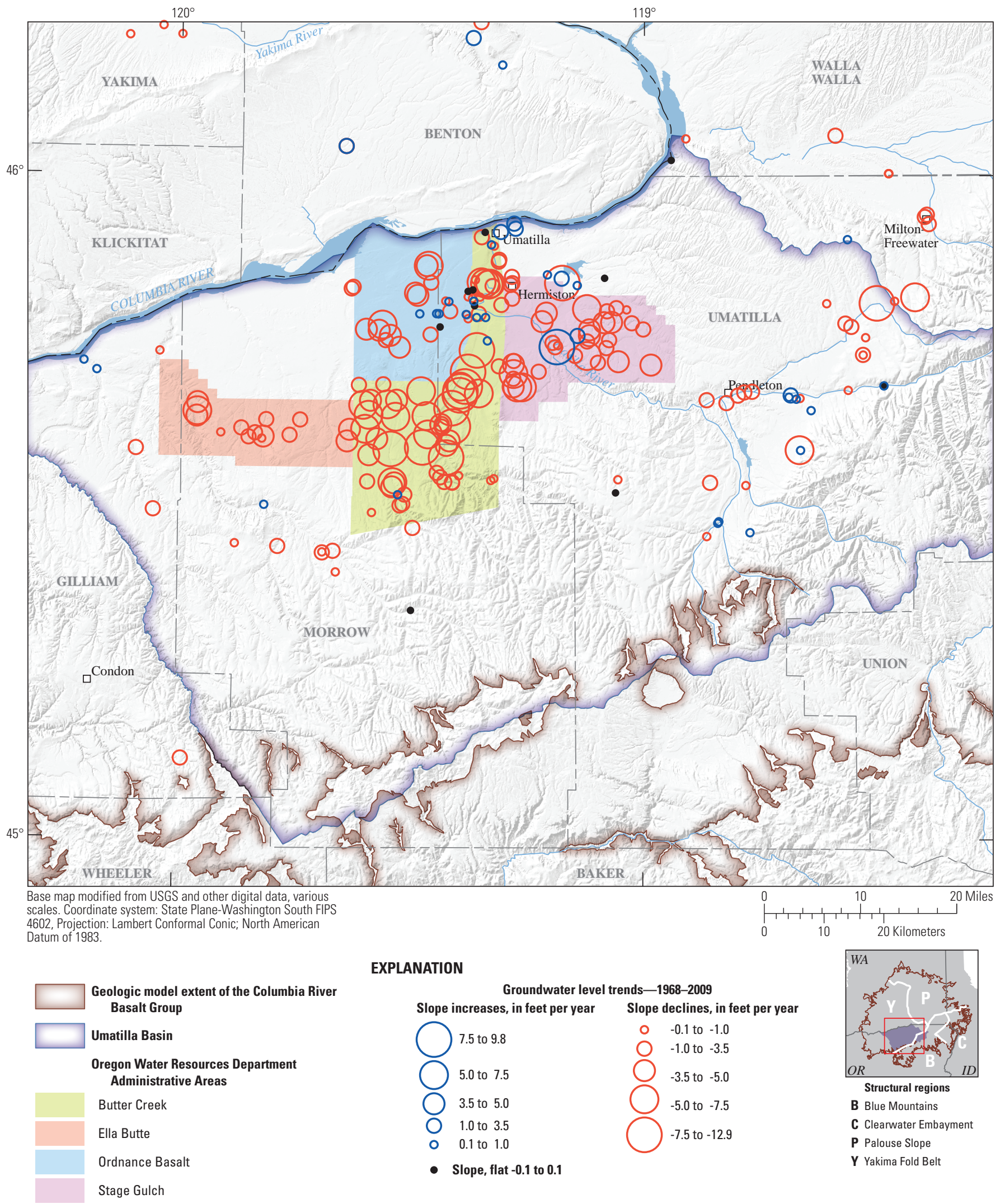

Figure 9. Distribution of groundwater-level trends for 1968-2009 in Oregon Water Resources Department administrative areas in the Umatilla Basin, Oregon. 


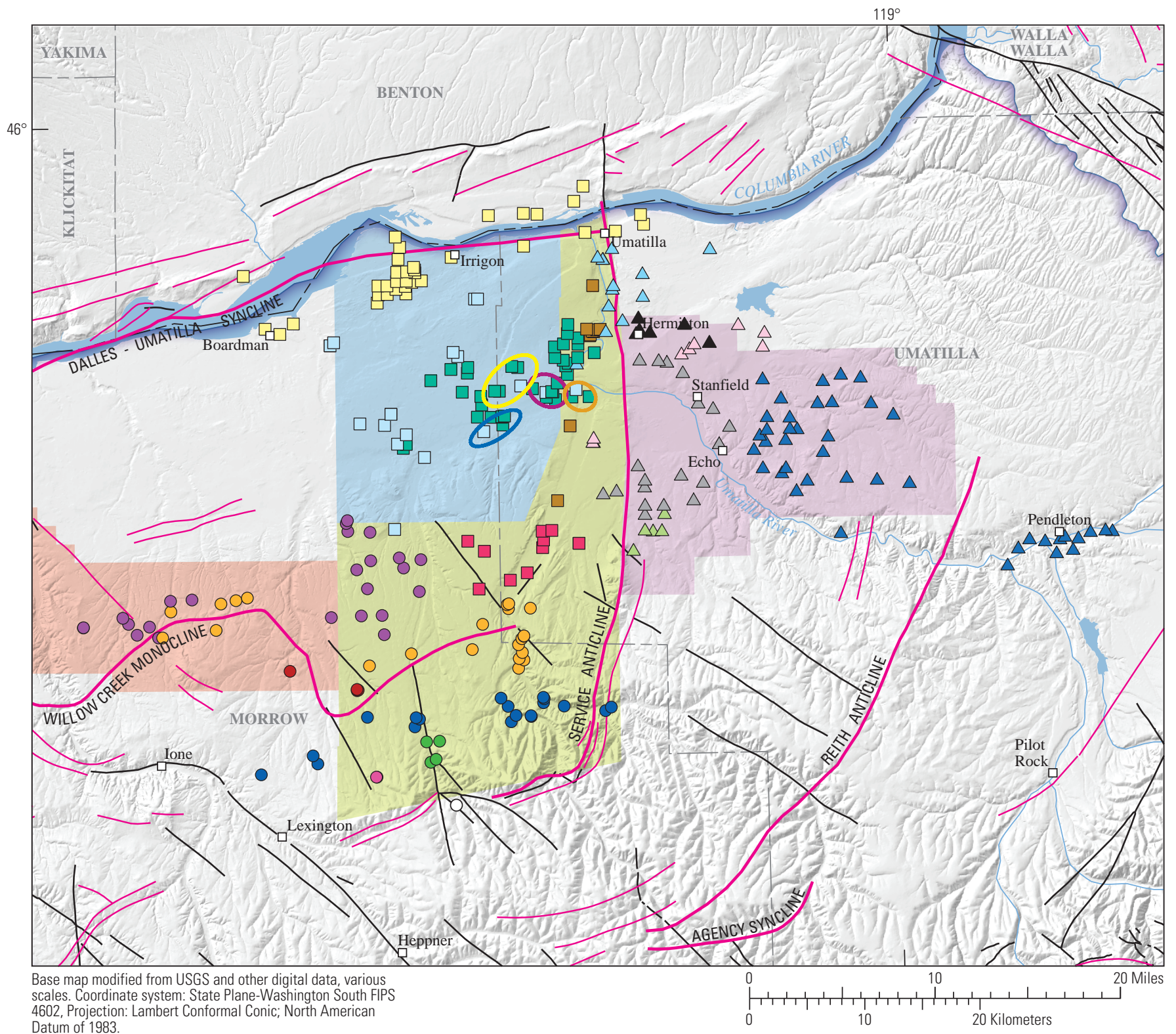

Datum of 1983

\section{EXPLANATION}

\begin{tabular}{|l|}
\hline Umatilla Basin \\
Oregon Water Resources Department \\
Administrative Areas \\
Butter Creek \\
Ella Butte \\
Ordnance Basalt \\
Stage Gulch \\
\hline
\end{tabular}

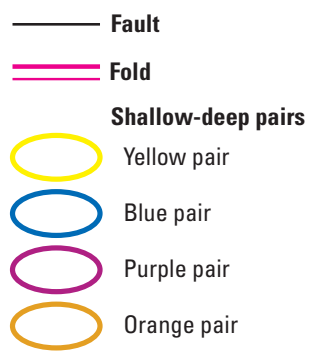

\begin{tabular}{cccc}
\multicolumn{3}{c}{ Wells by group } & \\
$\square$ & Group 1 & $\bigcirc$ & Group 10 \\
$\triangle$ & Group 2 & $\triangle$ & Group 11 \\
$\square$ & Group 3 & $\triangle$ & Group 12 \\
$\bigcirc$ & Group 4 & $\Delta$ & Group 13 \\
& Group 5 & $\square$ & Group 14 \\
$\triangle$ & Group 6 & $\bigcirc$ & Group 15 \\
$\square$ & Group 7 & $\bigcirc$ & Group 16 \\
$\square$ & Group 8 & $\bigcirc$ & Group 17 \\
$\triangle$ & Group 9 & $\bigcirc$ & Group 18
\end{tabular}

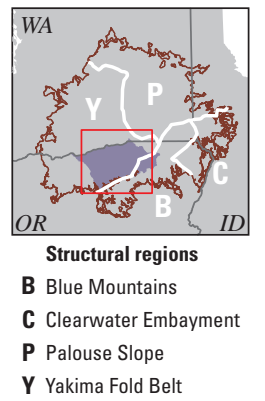

Figure 10. Groups of wells with similar hydraulic response near the Oregon Water Resources Department administrative areas in the Umatilla Basin, Oregon. Wells are grouped to show a general North-South transect (circles and squares) and a general EastWest transect (triangles and squares) (fig. 11). 


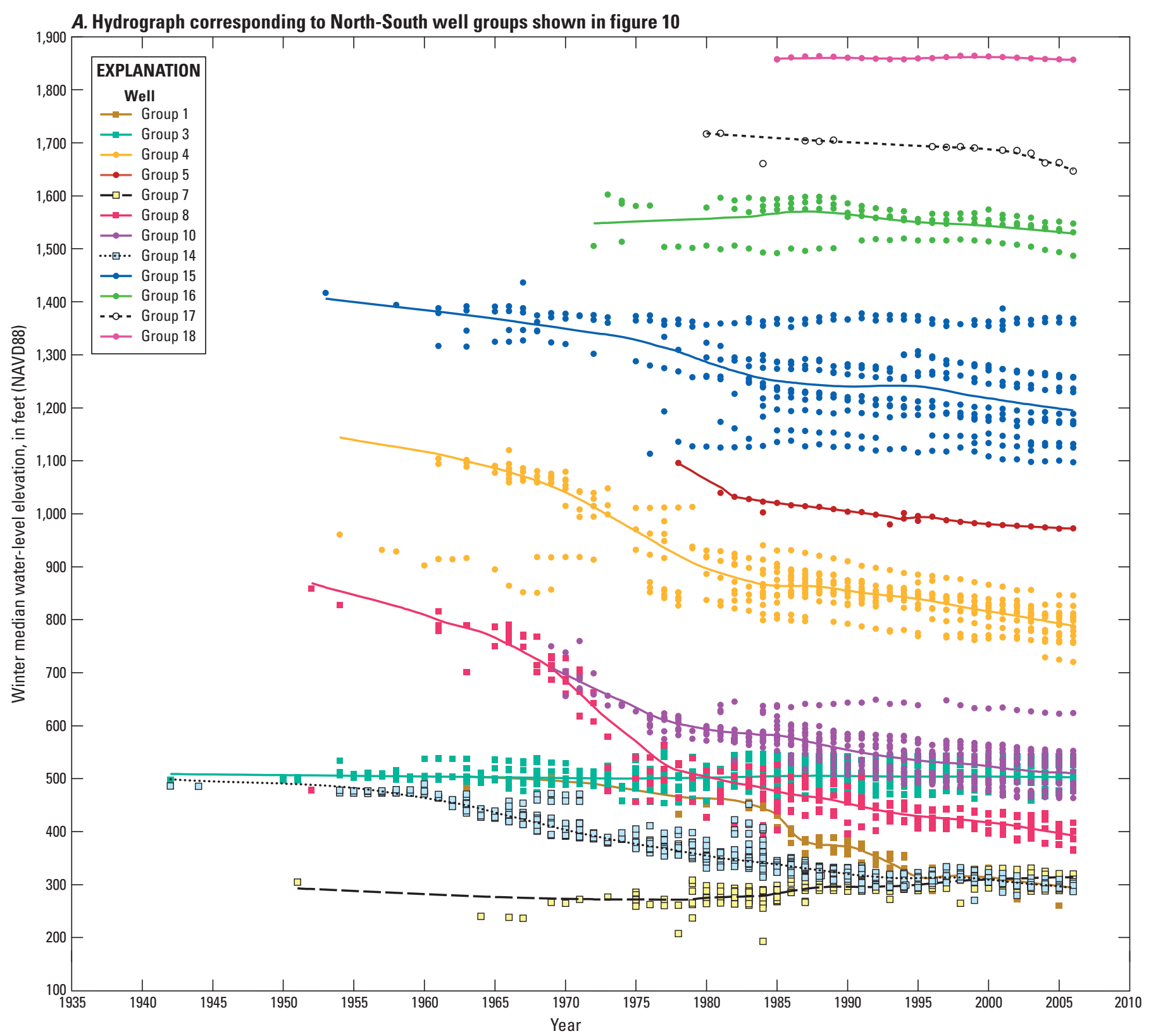

Figure 11. Groups of wells near the Oregon Water Resources Department administrative areas in the Umatilla Basin, Oregon. $(A)$ North-South group (circles and squares); and $(B)$ East-West group (triangles and squares). Hydrographs depict the winter median water level for individual wells within each well group and LOESS curve representing the overall water-level trend of all wells in the group. Locations of wells are shown in figure 10. 
B. Hydrograph corresponding to East-West well groups shown in figure 10

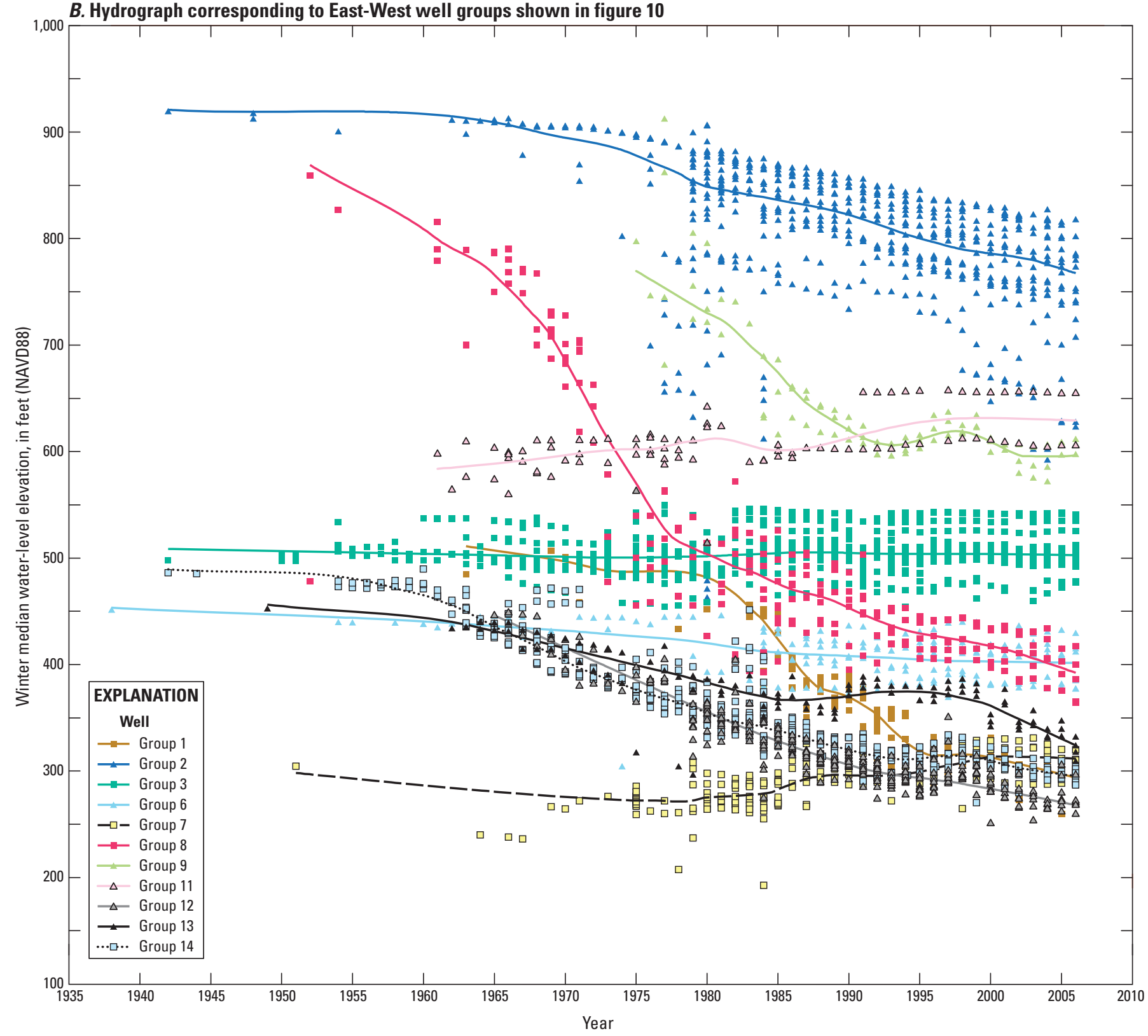

Figure 11.-Continued 


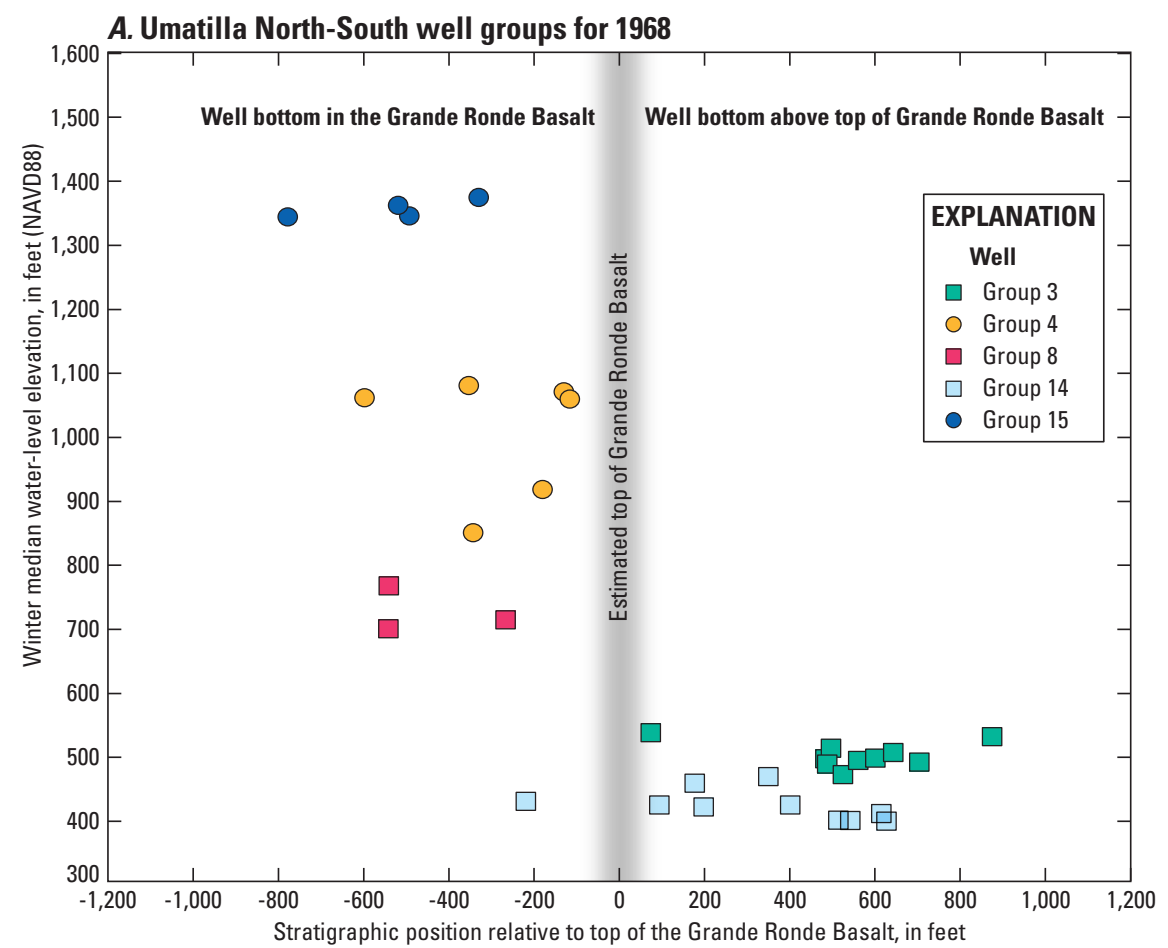

Figure 12. Estimated stratigraphic position (distance from the well bottom to the simulated top of Grande Ronde Basalt) compared with winter median water-level elevation in selected wells within and immediately adjacent to the Oregon Water Resources Department administrative areas in the Umatilla Basin, Oregon, 1968, 1984, and 2006. ( $A-C$ ) North-South group; and $(D-F)$ East-West group. Locations of groups are shown in figure 10. 


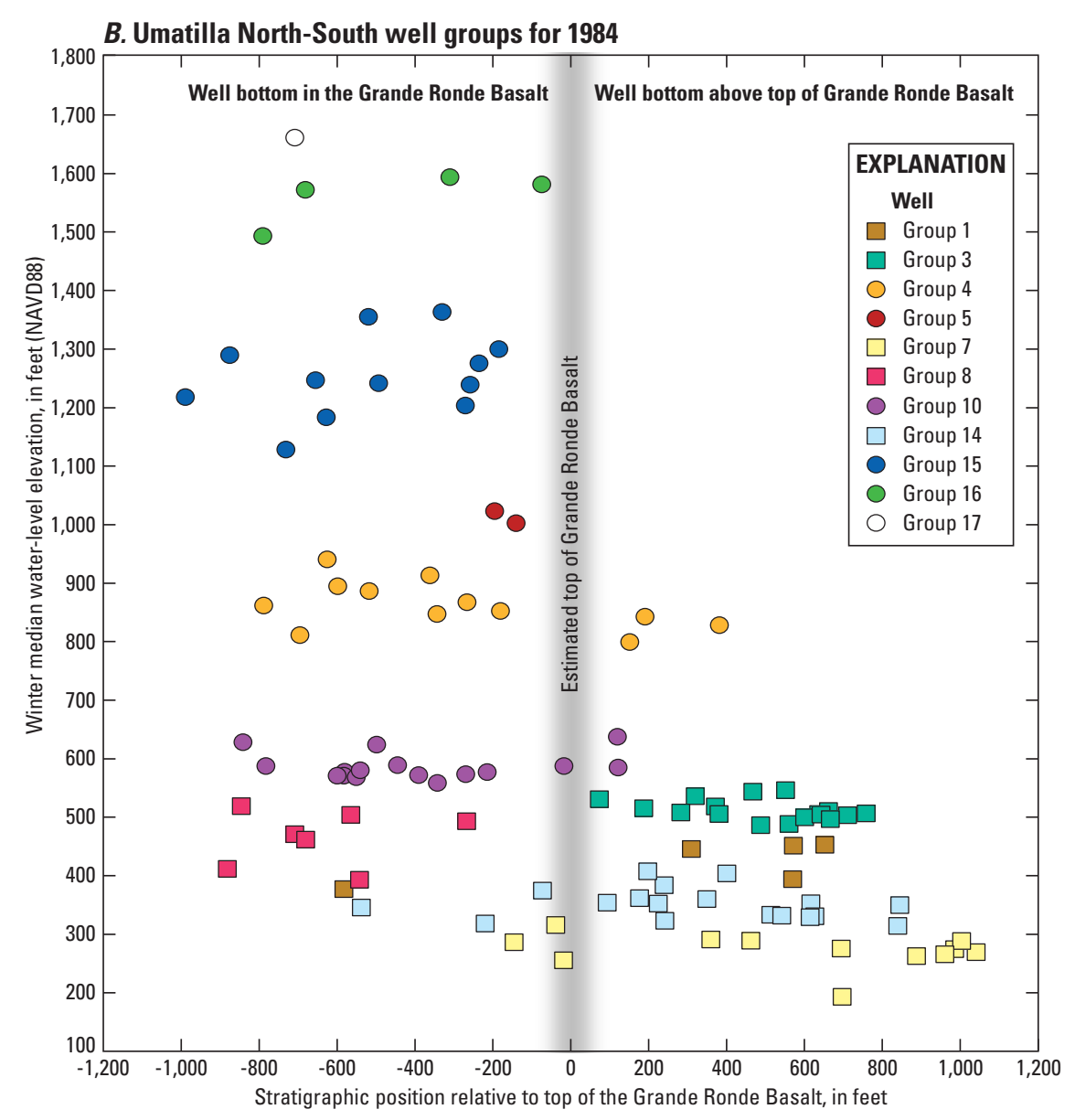

Figure 12.-Continued 


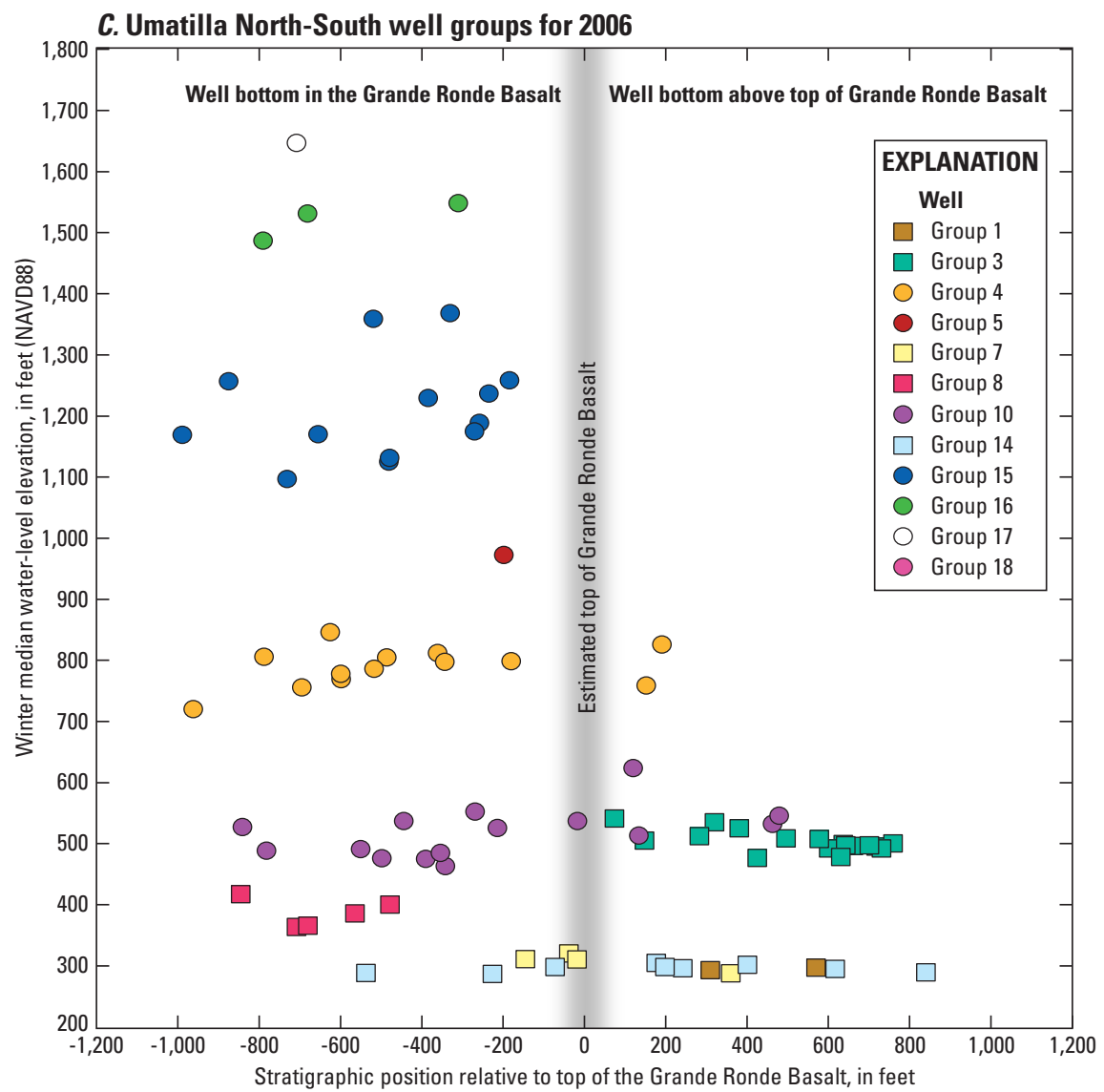

D. Umatilla East-West well groups for 1968

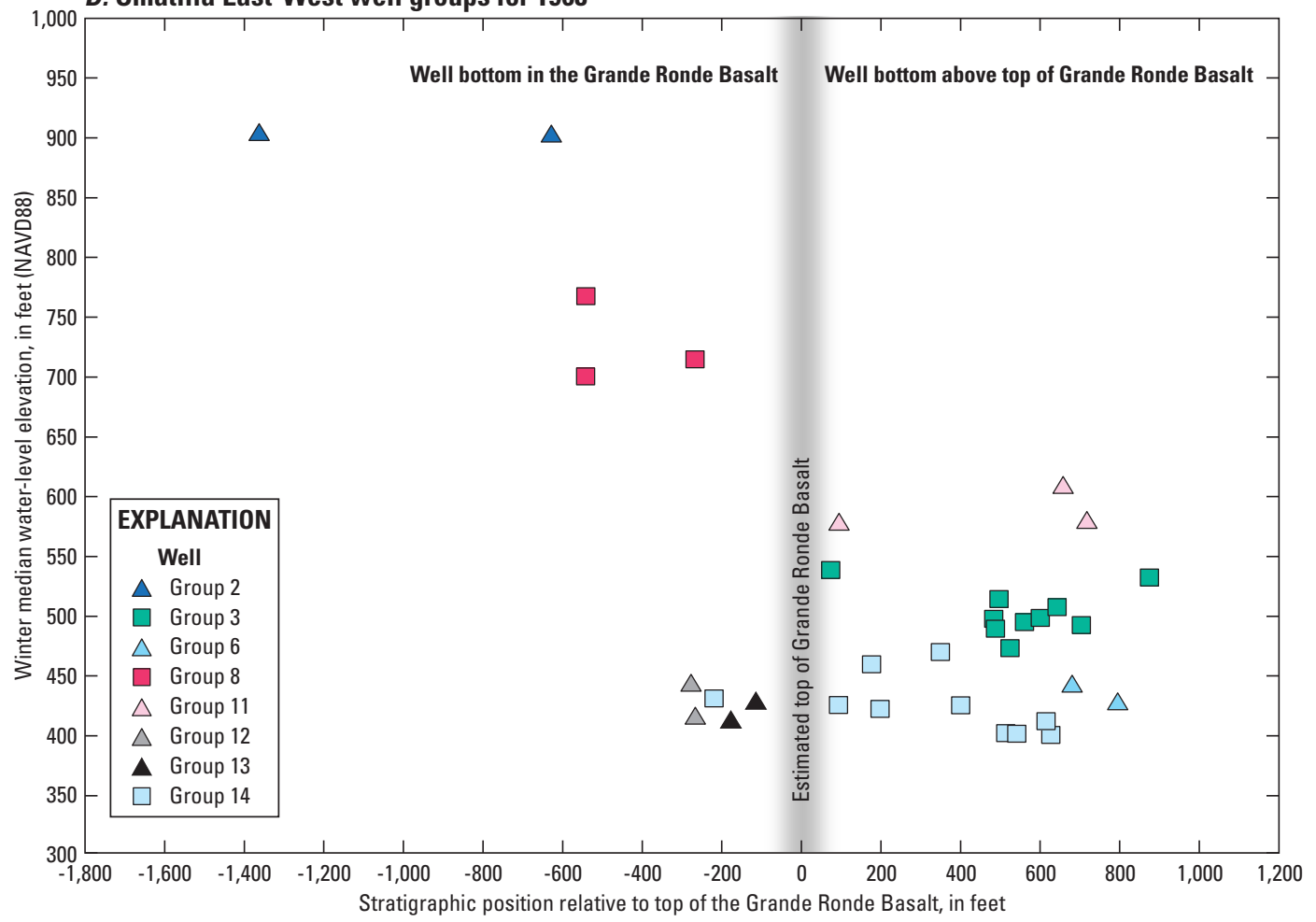

Figure 12.-Continued 
E. Umatilla East-West well groups for 1984
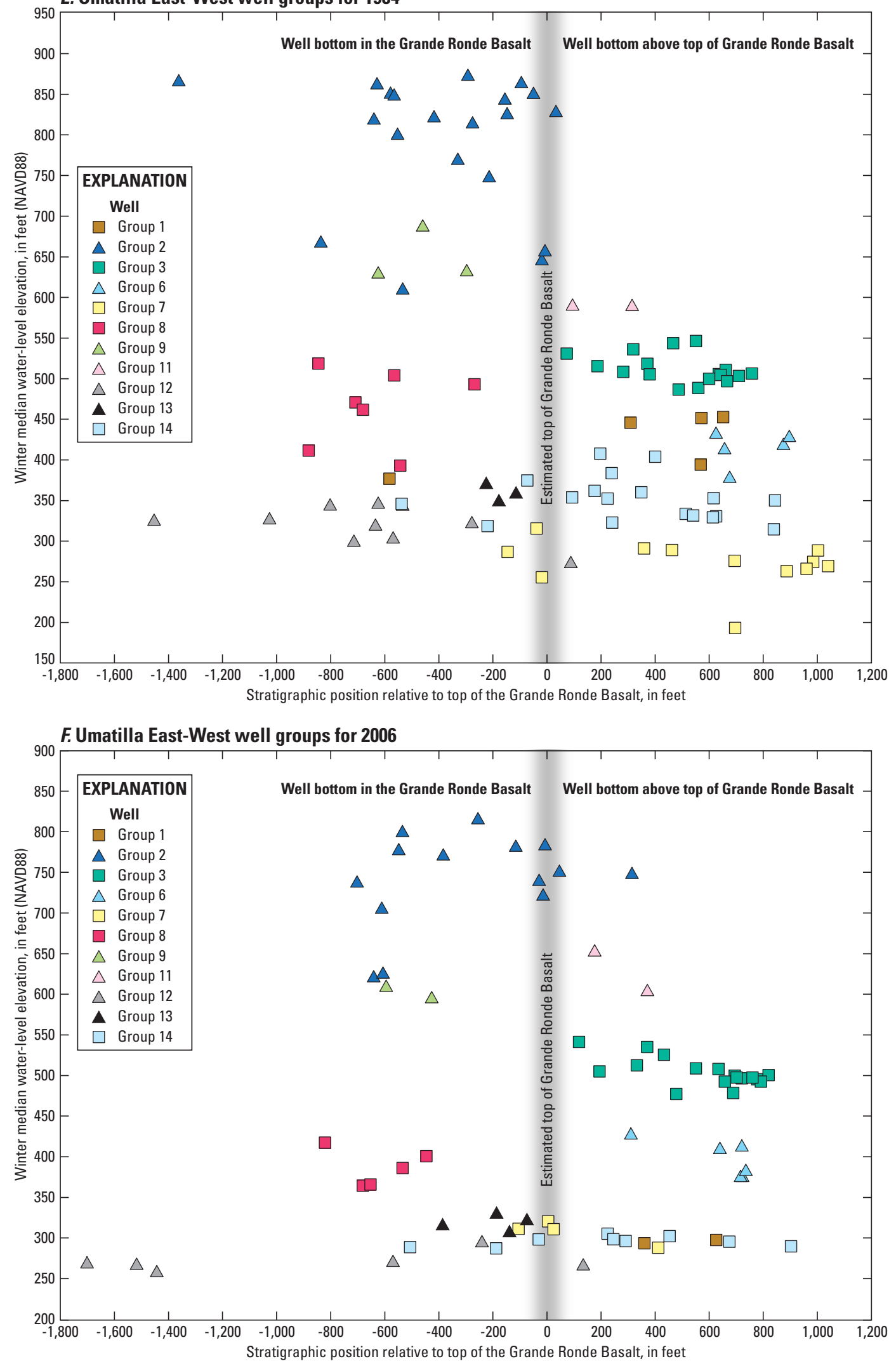

Figure 12.-Continued 


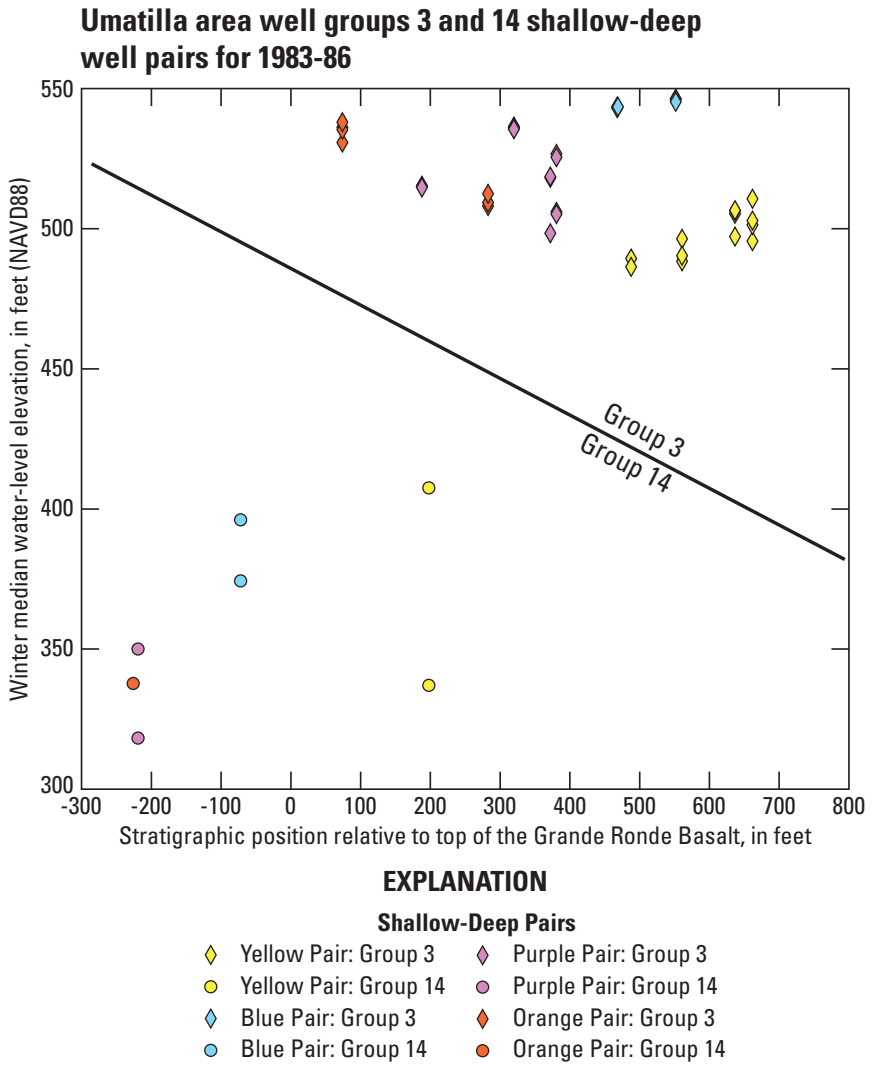

Figure 13. Stratigraphic position (distance from the well bottom to the simulated top of Grande Ronde Basalt) compared with winter median water level measured in wells for shallow-deep well pairs from groups 3 and 14 near the Oregon Water Resources Department administrative areas in the Umatilla Basin, Oregon. Colors of points correspond to colors of shallow-deep pair circles in figure 10.
Barriers to groundwater flow result from primary characteristics of the basalt, the depositional environment, and post-depositional folding and faulting. Vertical flow barriers typically result when aquifers are separated by dense impermeable CRBG lava flow interiors that are laterally extensive. Near flow margins, however, the dense interiors are discontinuous, and aquifers may be well-connected hydraulically. In the OWRD administrative areas, vertical separation is apparent only in the groundwater-level data near groups 6 (light blue triangles), 11 (pink triangles), and 14 (light blue squares), which have higher hydraulic heads than nearby wells completed in lower stratigraphic units. For example, the head in group 3 wells stayed nearly constant at about $500 \mathrm{ft}$, whereas the deeper group 14 wells have shown declines in groundwater elevation from about 450 to about $300 \mathrm{ft}$ since the 1960s (fig. 11B).

For all other well groups, there is a conspicuous lack of vertical hydraulic gradients across thick sequences of lava that should contain many individual lava flows. Within most groups a uniform hydraulic head exists across thousands of feet of basalt thickness despite the fact that many (approximately 100-ft thick) lavas are intersected (fig. 12A-F; ideal behavior is shown in fig. A1D). These hydraulic heads are uniform even though the older lava flows were more extensive than the younger flows, which implies that dense flow interiors should separate the aquifers, creating the conditions necessary for vertical hydraulic gradients. The uniformity of hydraulic heads in these aquifers may be the result of hydraulic equilibration through commingling wells. For confined or other low storage aquifers, time for equilibration can be short. In the Mosier Watershed, Oregon, commingled wells equilibrated within 2 years (Burns and others, 2012). Because groundwater-level monitoring typically begins after multi-year declines have been documented, data representing pre-commingling conditions are limited. 
Examination of the mapped geologic structure shows horizontal compartmentalization is frequently correlated to the structure, although not always. The correlation along the Willow Creek monocline in groups 4 (orange circles), 5 (dark red circles), 10 (purple circles), and 15 (dark blue circles) show consistent head patterns along the sinuous fold structure and high head differences between the groups across the fold indicating that the fold functions as a longitudinal conduit and a perpendicular barrier to groundwater flow (figs. 10 and 11A). The Service anticline also is an apparent horizontal flow barrier, although the deeper aquifers have complex, yet similar patterns particularly later in time, which indicates that some aquifers may be better hydraulically connected across the structure than others, indicating that commingling may be rendering this barrier less effective over time. To the contrary, the Reith anticline apparently is not a horizontal barrier to flow between the Pendleton area and the eastern side of the Stage Gulch administrative area as evidenced by group 2 wells (dark blue triangles) in figure 11B. From north to south, the hydraulic gradients increase proportionally to the amount of geologic structure (compare water levels from figure 11A to the well locations in figure 10), indicating that geologic structure may be impeding lateral recharge from the uplands. Curiously, the exceptionally high hydraulic head contrast between groups 2 and 12 (gray triangles) (figs. 10 and $\underline{12 D}-\underline{E}$ ) does not correspond to a mapped geologic structure, indicating the presence of a previously unmapped geologic feature.

Near the OWRD administrative areas, a few shallow CRBG aquifers (groups 3 [dark green squares], 6 [light blue triangles], 7 [yellow squares], and 11 [pink triangles]) are receiving recharge from irrigation projects and have stable or slightly rising hydraulic heads (fig. 11B). Water levels in many of the deeper CRBG aquifers, in contrast, have declined 100-300 ft since 1970 as shown in groups 4 (orange circles), 8 (red squares), 10 (purple circles), and 14 (light blue squares) (fig. 11A). Hydraulic heads in groups 15 [dark blue circles], 16 [green circles], 17 [white circles], and 18 [magenta circles] (figs. 10 and $11 \mathrm{~A}$ ) to the south have lower total decline because they are protected from the high pumping rates in the north by horizontal flow barriers immediately north of these groups.

\section{Palouse Slope/Eastern Yakima Fold Belt, Washington}

The Palouse Slope and the eastern Yakima Fold Belt (fig. 1), which forms a transition area between the two physiographic provinces, encompass the entire area of the Columbia Basin GWMA (hereafter referred to as the Palouse Slope/eYFB). Within the GWMA, WADOE has established several administrative areas (Ground Water Management Subareas) that cover most locations with large long-term groundwater-level declines (Washington State Department of Ecology, 1988a, 1988b, and 1988c). These include the Odessa, Quincy, and 508-14 subareas (fig. 14). The largest groundwater-level declines measured in the central GWMA (1968-2009) are along a north-south swath near the center of the area (fig. 14). Hydrographs for 1,195 wells blanketing the area of largest declines in the CRBG aquifers were examined and divided into groups of wells exhibiting similar changes in hydraulic head over time and a subset of these groups was selected to illustrate these trends (fig. 15). Horizontal barriers to flow are not as evident in this area as in the Umatilla area, but groups are still identifiable based on similar response to hydraulic stresses. This is consistent with the geologic interpretation of the Palouse Slope as being a gently folded structure created during subsidence where CRBG lavas were deposited in voluminous sheet flows. For this area, hydrographs of well groups are most easily viewed along general flow paths that have developed as the result of irrigation stresses on the aquifer system (ig. 15). These flow paths generally trend toward the area with large declines (fig. 14).

Figures 16-19 present hydrographs showing the winter median water levels for individual wells within each well group shown in figure 15 and the trend line for each group constructed using the statistical software program, TIBCO Spotfire S+ (TIBCO Software, Inc., 1988-2008). Water levels in wells in groups 1 (pink circles), 2 (light blue circles), 3 (dark green circles), and 4 (black circles and white circles for shallow and deep wells, respectively) associated with the western flow path (shown as circles in figure 15) start to rise during the 1950s (fig. 16). Prior to 1950, the limited data suggest lower groundwater levels and flatter hydraulic gradients. After 1950, groundwater levels rise and the hydraulic gradient steepens from west to east indicating increased groundwater flow toward Moses Lake and farther east where groundwater declines are associated with widespread irrigation from groundwater. 


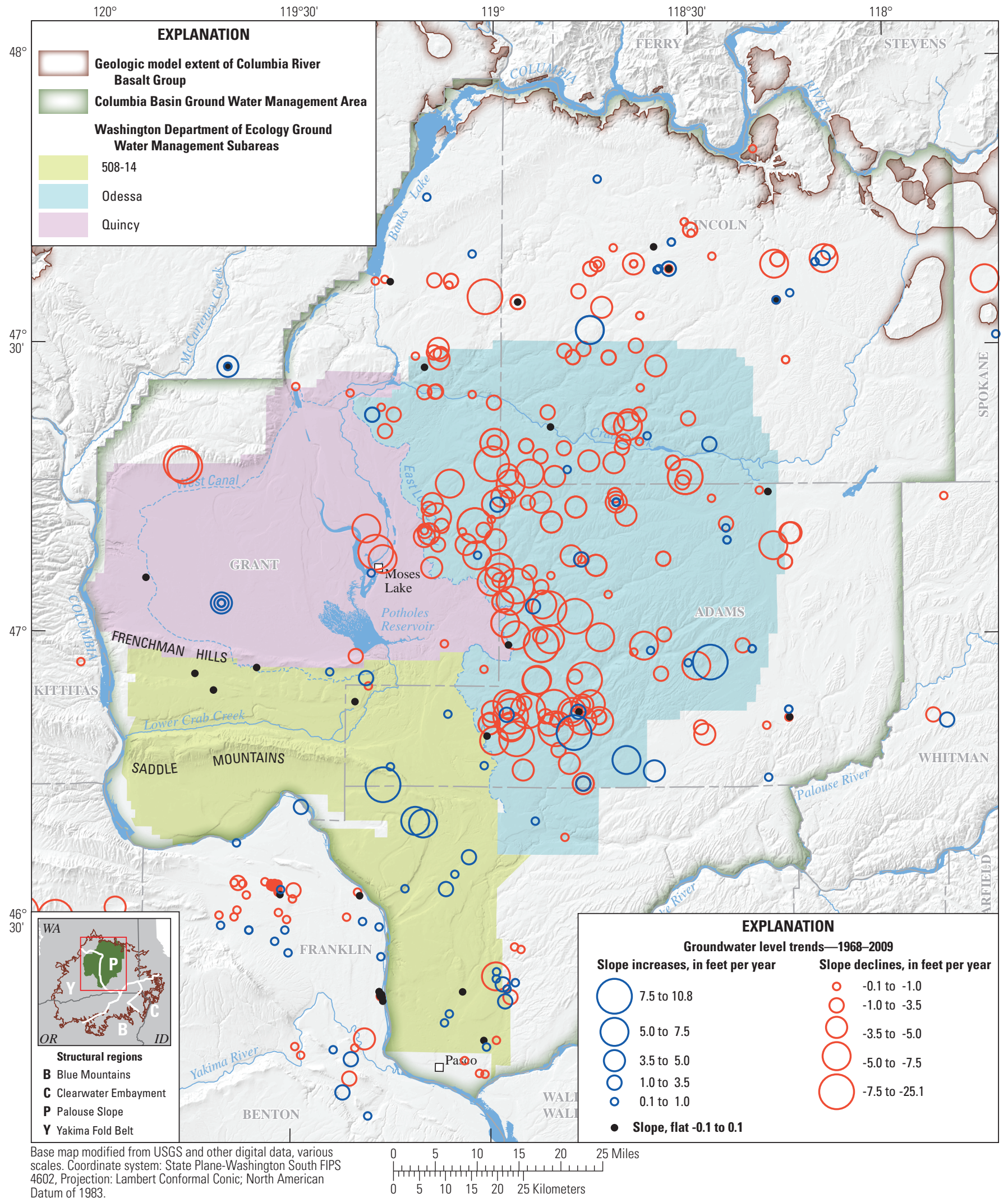

Figure 14. Distribution of groundwater-level trends for 1968-2009 relative to the Washington State Department of Ecology administrative areas in parts of the Palouse Slope/eastern Yakima Fold Belt and the Columbia Basin Ground Water Management Area, Washington. 


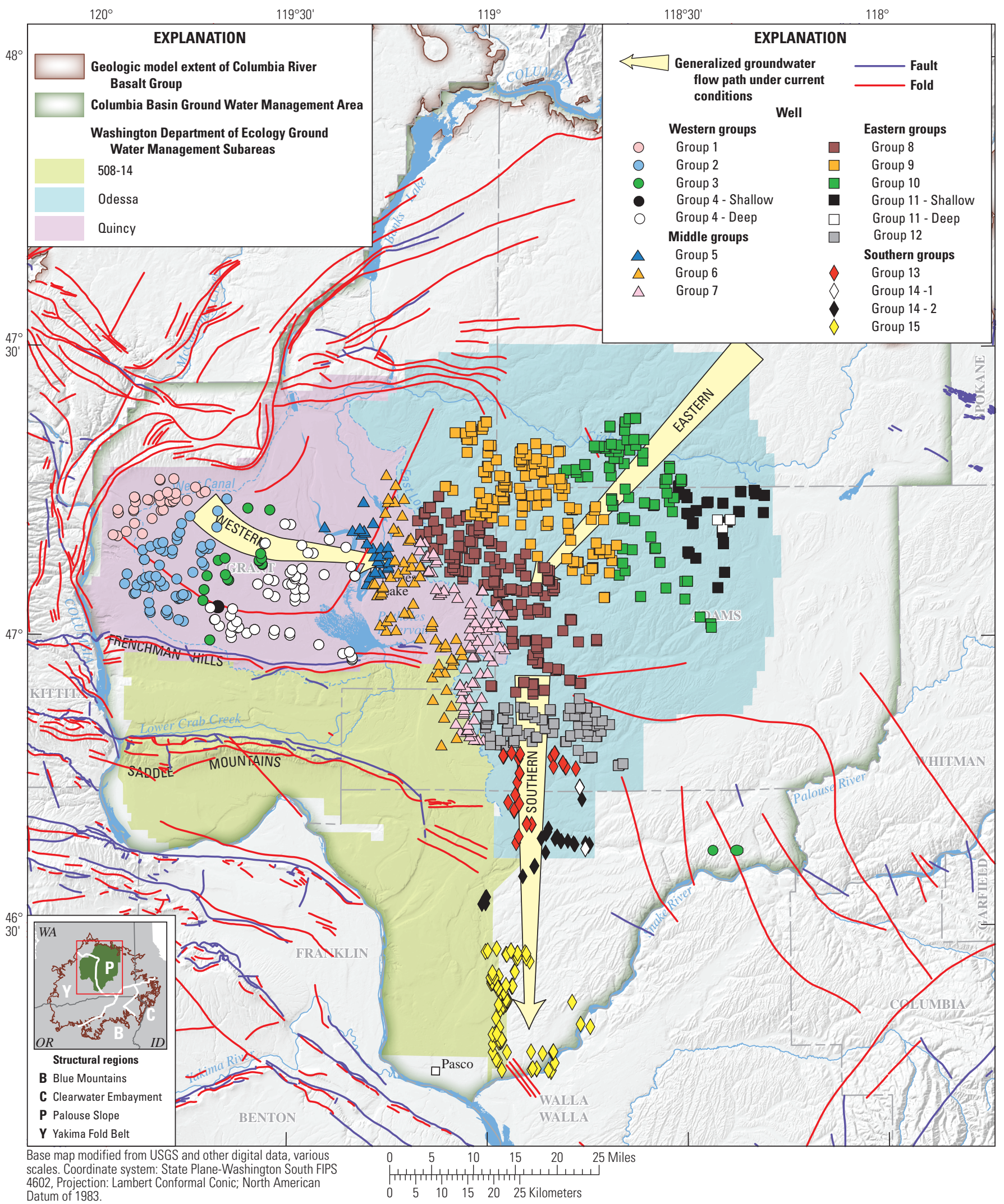

Figure 15. Generalized groundwater-flow paths under 2000-2010 conditions through sets of well groups with similar hydraulic response near the Washington State Department of Ecology administrative areas in parts of the Palouse Slope/eastern Yakima Fold Belt and the Columbia Basin Ground Water Management Area, Washington. 


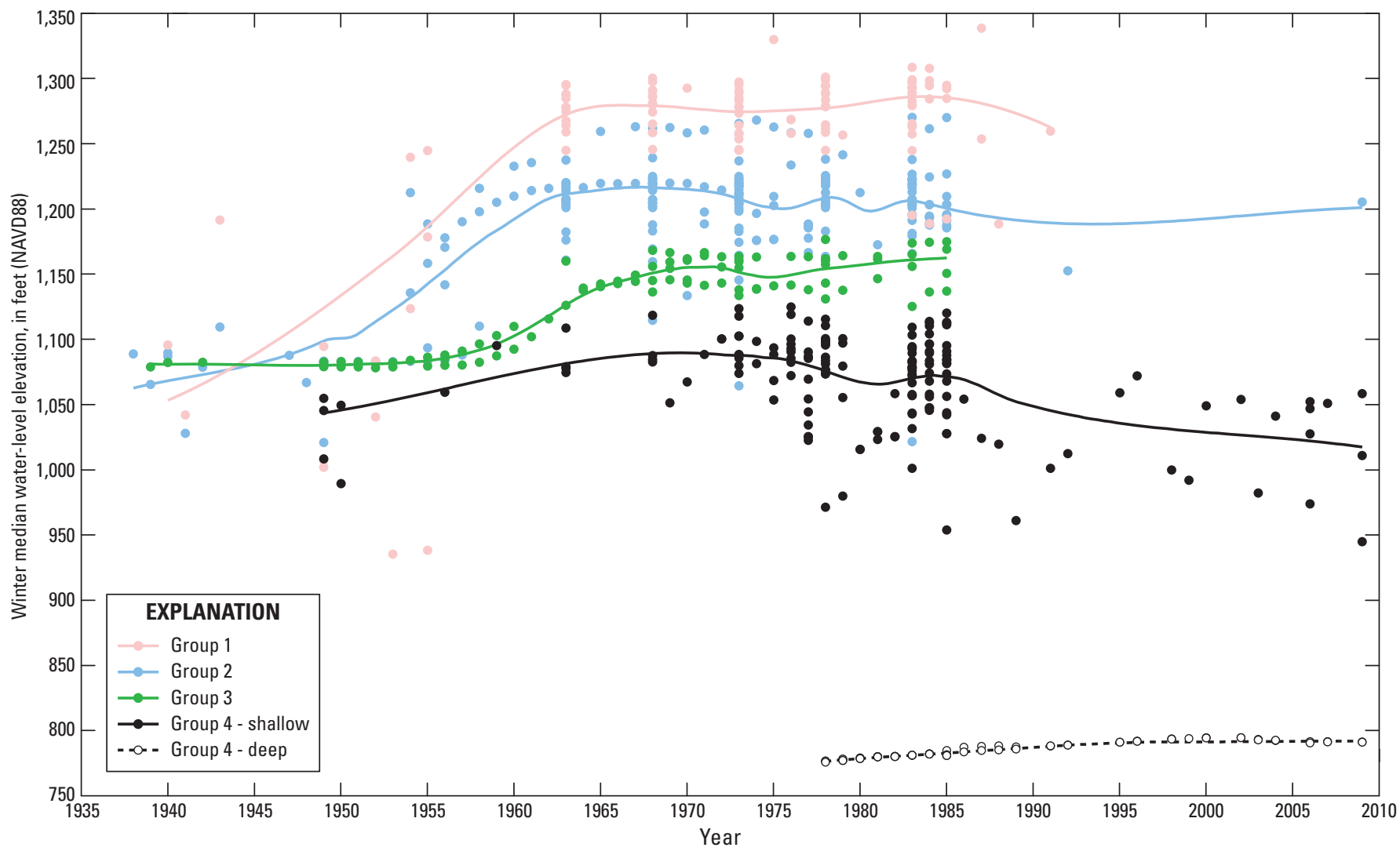

Figure 16. Groups of wells corresponding to the western flow path near the Washington State Department of Ecology administrative areas in parts of the Palouse Slope/eastern Yakima Fold Belt and the Columbia Basin Ground Water Management Area, Washington. Hydrographs depict the winter median water level for individual wells within each well group and the trend line representing the overall water-level trend of all wells in the group. Well locations and flow paths are shown in figure 15.

The wells in groups 8 (brown squares), 9 (orange squares), 10 (dark green squares), 11 (black squares and white squares, shallow and deep), and 12 (gray squares) associated with the eastern flow path (shown as squares in figure 15) show a hydraulic gradient sloping from northeast to southwest, down the Palouse Slope (fig. 17). Water-level declines for most of these wells begin after 1970. Group 11 shallow wells (black squares) are less affected, indicating hydraulic separation between most of these wells and the wells downslope (to the west). The wells showing significant declines exhibit various decline patterns, although total drawdown is similar in most wells.

Between the eastern and western flow paths and well groups, there is a middle set of well groups, groups 5 (dark blue triangles), 6 (orange triangles), and 7 (pink triangles), (shown as triangles in figure 15), with transitional behavior of groundwater levels. Groundwater levels in most of these wells begin to increase about 1950, as observed with the western well groups. Some of these wells also show groundwater-level declines starting in the 1970s as observed with the eastern well groups (fig. 18). Since 1970, a groundwater mound has formed between Moses Lake, Potholes Reservoir, and the eastern flow path wells. Groundwater-levels in groups 6 (orange triangles) and 7 (pink triangles) generally are higher than in groups to the east and west, which consist of group 4 shallow (black circles), group 5 (dark blue triangles), group 8 (brown squares), and group 12 (gray squares) (figs. 15-18).

The southern well groups (groups 13 [red diamonds], 14 [black diamonds and white diamonds], and 15 [yellow diamonds]) associated with the southern flow path (shown as diamonds in figure 15) show a hydraulic gradient from north to south toward the Snake River (fig. 19), which locally has an elevation of about $350 \mathrm{ft}$. The hydraulic behavior is complex, although the narrow spacing between adjacent well groups and dissimilar temporal changes indicates there may be some hydraulic barriers between these groups. 


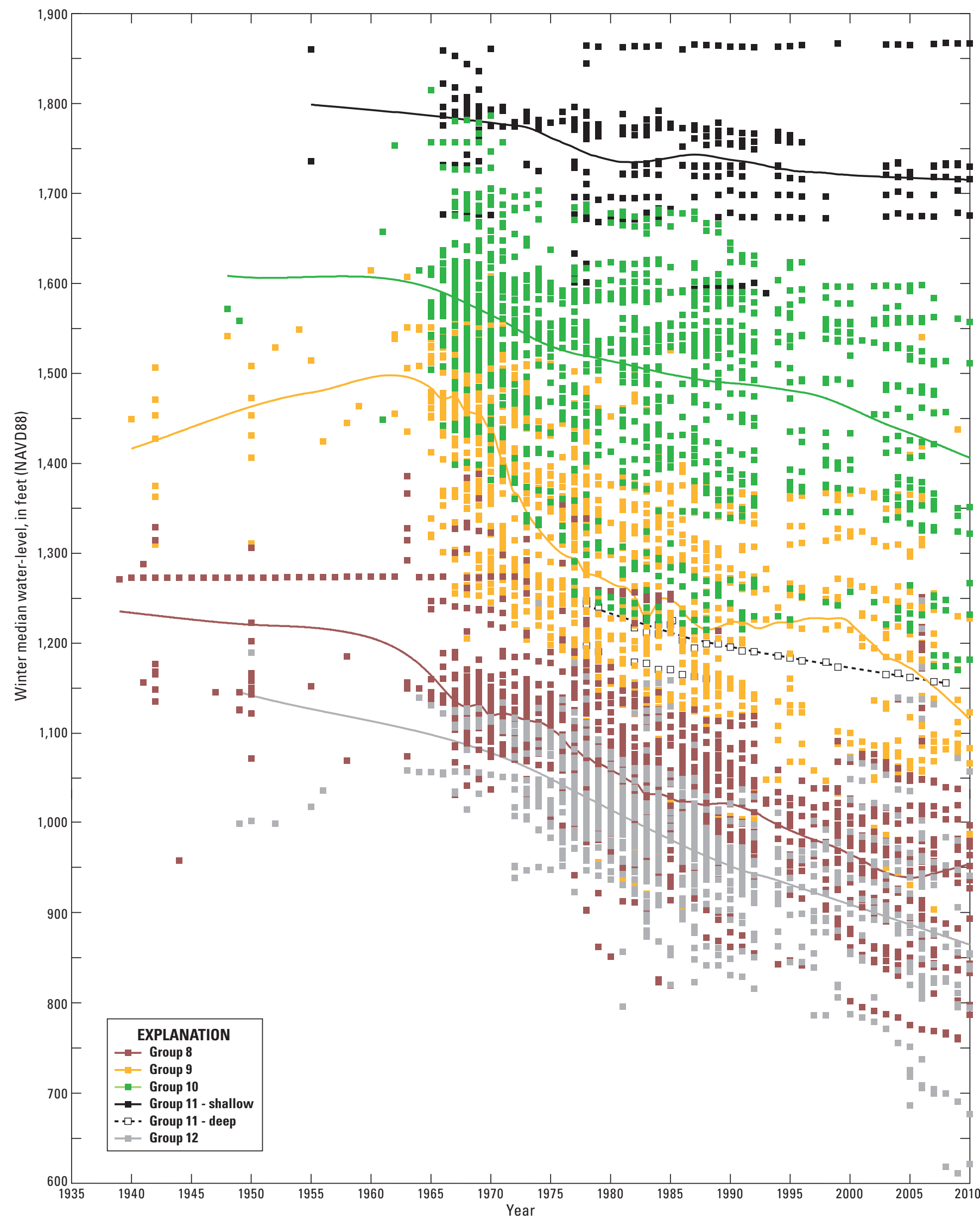

Figure 17. Groups of wells corresponding to the eastern flow path near the Washington State Department of Ecology administrative areas in parts of the Palouse Slope/eastern Yakima Fold Belt and the Columbia Basin Ground Water Management Area, Washington. Hydrographs depict the winter median water levels for individual wells within each well group and the trend line representing the overall water-level trend of all wells in the group. Well locations and flow paths are shown in figure 15. 
The hydraulic behavior of group 12 (gray squares) is at the nexus of the eastern, middle, and southern well groups and apparently is influenced by each of the adjacent groups (figs. 17 and 19), although its component wells are not easily separated into the adjacent groups based on location. Hydraulic head values for group 12 wells commonly are intermediate between the other groups, with some wells exhibiting declines similar to group 8 (brown squares) wells from the eastern well groups (fig. 17), and other group 12 water levels rising similarly to water levels in group 7 wells (pink triangles) from the middle well groups (fig. 18). No clear pattern of depth or location allows group 12 wells to be subdivided into the adjacent groups.

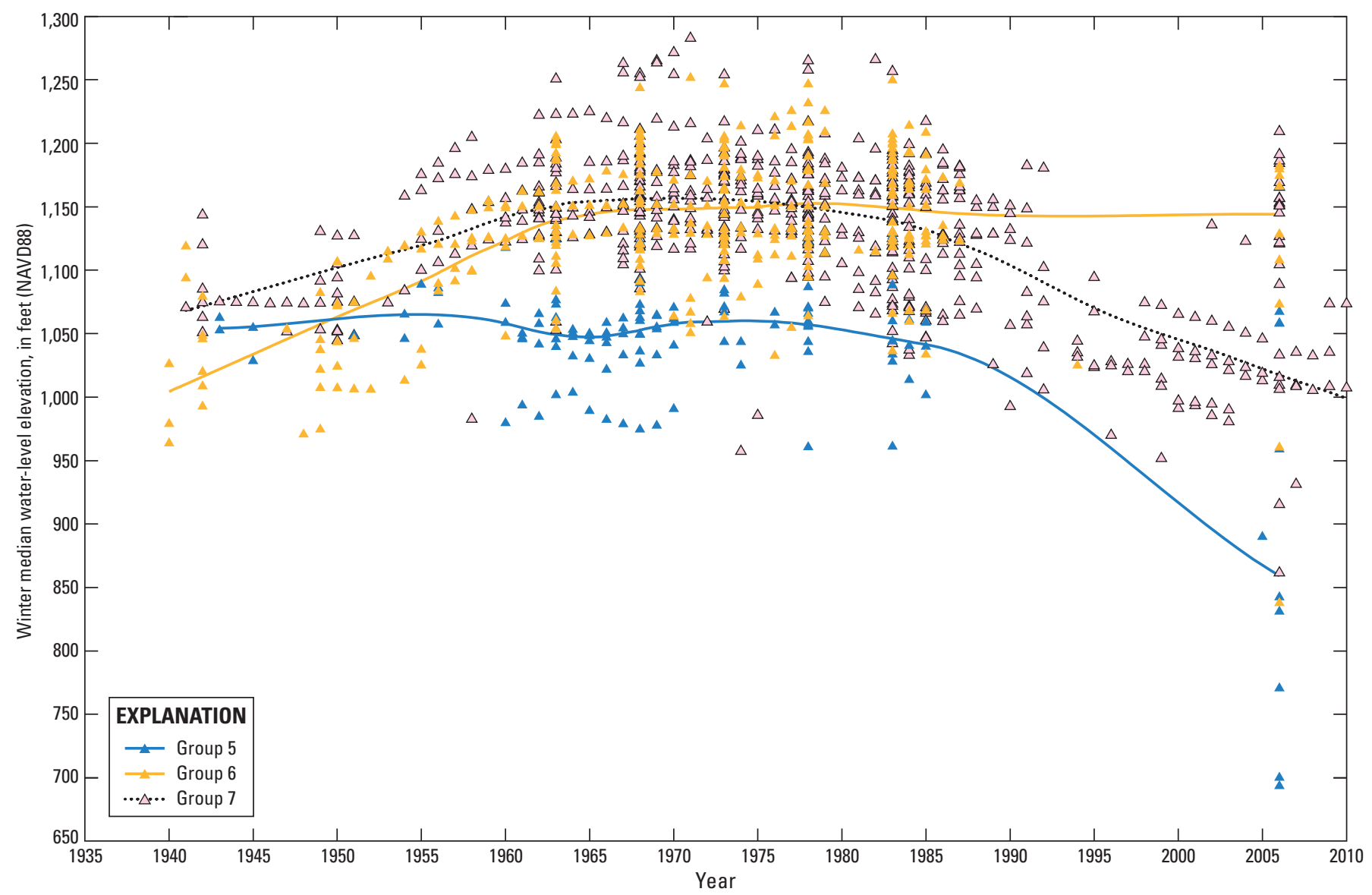

Figure 18. Middle groups of wells near the Washington State Department of Ecology administrative areas in parts of the Palouse Slope/eastern Yakima Fold Belt and the Columbia Basin Ground Water Management Area, Washington. Hydrographs depict the winter median water levels for individual wells within each well group and the trend line representing the overall water-level trend of all wells in the group. Well locations are shown in figure 15. 


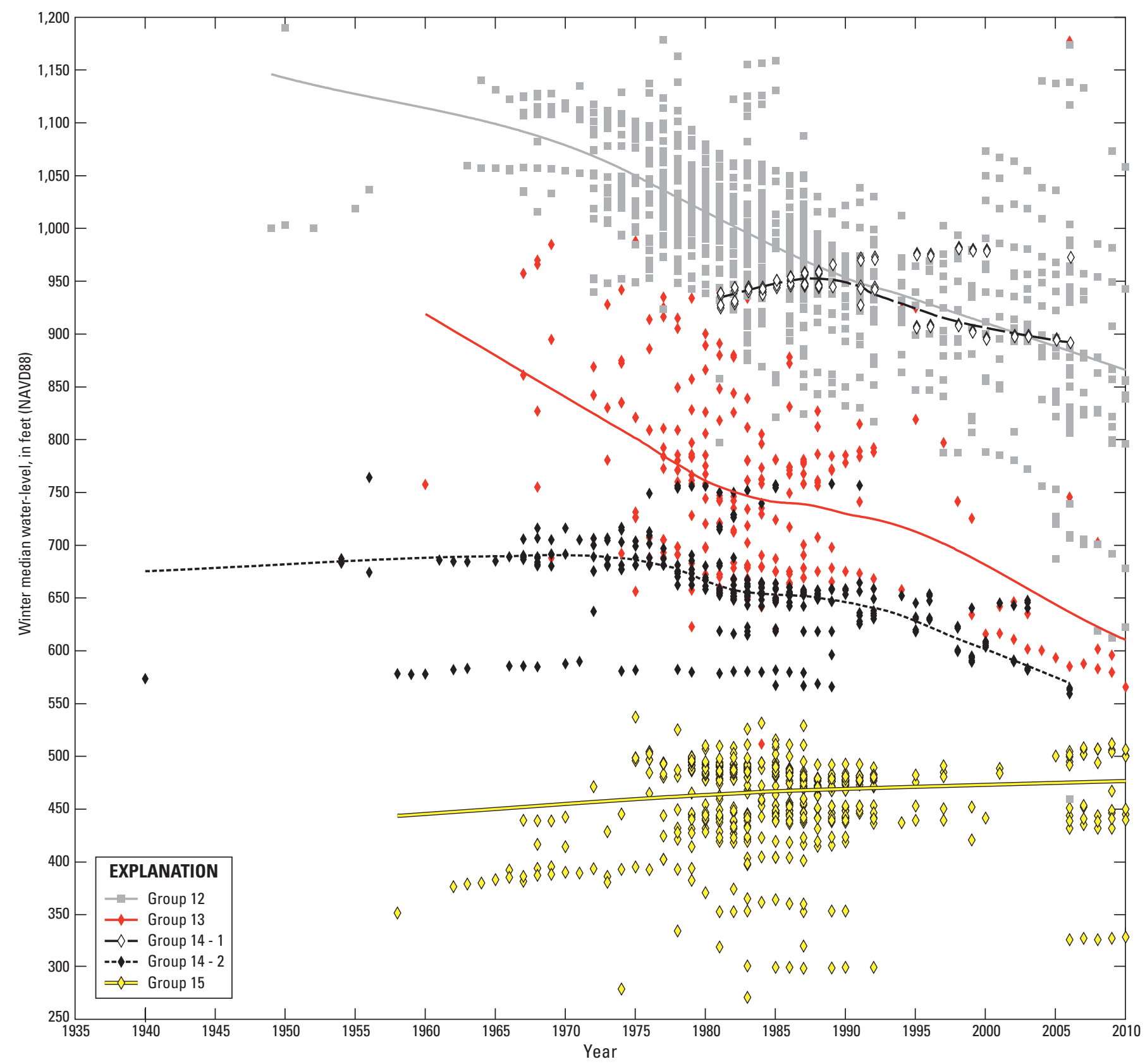

Figure 19. Groups of wells corresponding to the southern flow path near the Washington State Department of Ecology administrative areas in parts of the Palouse Slope/eastern Yakima Fold Belt and the Columbia Basin Ground Water Management Area, Washington. An additional hydrograph for a proximal group of wells (group 12) is shown to illustrate the relation between well groups. Hydrographs depict the winter median water levels for individual wells within each well group and the trend line representing the overall water-level trend of all wells in the group. Well locations and flow paths are shown in figure 15. 
Water levels on the Palouse Slope/eYFB were plotted against stratigraphic position relative to the simulated top of the Grande Ronde Basalt (fig. 20A-1). Analogous to the head distribution in the Umatilla area, heads are similar over large vertical intervals of basalt in the Palouse Slope/eYFB area indicating possible commingling of aquifers. Unlike the Umatilla area, even within a well group and for closely spaced wells, those wells constructed at the same elevation may have hydraulic heads hundreds of feet different from each other. This noisy data and the lack of apparent flow barriers between well groups, results in overlap of the hydrographs between groups. Even within well groups, division of hydrographs by approximate stratigraphic layer does not yield smoothlyvarying groundwater-level data that generates well-behaved potentiometric surface maps. This may be due to the complex connectivity between wells and commingled aquifers resulting in a range of composite head elevations (ig. 6).

Generalized potentiometric surfaces were developed for pre-development conditions (prior to 1951; fig. 21) and post-2000 conditions (fig. 22). Relatively high-error generalized surfaces were created using all CRBG wells without distinction between CRBG hydrogeologic unit because hydrographs within well groups show consistent general trends (figs. 16-19); however, few measurements within each group support the division of wells into hydraulically distinct zones vertically (fig. 20). Figures 21 and 22 were constructed by using median water levels for the defined periods for each CRBG well, and smoothing the data with LOESS local linear trend models (Cleveland and others, 1992). At any location, potential error of the simulated hydraulic head is high; the measured value could be hundreds of feet higher or lower than these generalized surfaces. Because trend models were used, fit is biased toward shallow data because few deep wells with significantly different water-levels were measured (ig. 20). However, when evaluating model fit, there is little spatial bias in the residuals between the measurement points and predicted surface; therefore, the resulting surfaces are good representations of the patterns in the hydrograph groups. Because of the large amount of smoothing of these potentiometric surfaces, smaller scale features associated with streams and structural barriers to flow, for example, the Frenchman Hills (ig. 1) are not well represented.

Groundwater flow during the pre-development period was from the uplands in the northeastern part of the GWMA toward the Columbia and Snake Rivers to the west and south, respectively (ig. 21). Although the locations where groundwater has the potential for local drainage to surface water features are shaded (fig. 21), the generalized potentiometric surface was not corrected for interaction with surface drainages because flow to local streams depends on the hydraulic head and local connection between the aquifers and the streams. Following the onset of large surface-water irrigation projects near Moses Lake (fig. 22) in the 1950s, water levels in the upper CRBG aquifers increased and formed a groundwater mound, resulting in a reversal of the hydraulic gradient toward the area of declines (compare figs. 14,21, and 22). For wells examined, groundwater levels under surface-water irrigation areas typically rise about $50 \mathrm{ft}$, with larger rises occurring locally (for example, in the fault bounded valleys to the south of the Frenchman Hills and the Saddle Mountains). To the east, in the south central area of the GWMA where groundwater pumping is the primary source of irrigation, a trough-shaped depression sloping toward the south has formed, and groundwater flows toward it from east and west (fig. 22). The axis of the trough generally is coincident with the easternmost area of dense irrigation pumping of groundwater shown in the center of figure 22, much of which is occupied by well group 8 (brown squares) in figure 15.

Because most well groups do not exhibit pronounced persistent vertical gradients, the potential for commingling to contribute to hydraulic head declines in this area is not clear from the data. The limited data show that a significant downward hydraulic gradient is present in the eastern and western well groups (group 4 shallow [black circles] and deep [white circles] wells in figures 16 and 20B-C, group 11 shallow [black squares] and deep [white squares] wells in figures 17 and 20E). Large vertical head differences apparently are abrupt in groups 4 and 11, while other well groups (for example group 10 [dark green squares] in figures 20E-F) show vertical gradients that are more continuous and exhibit considerable variability. The downward vertical gradients are consistent with the geologic model (Burns and others, 2011) that shows the deeper aquifers are exposed through erosion along the Snake and Columbia Rivers at elevations consistent with the lower hydraulic heads in these deeper units. In addition, hydraulic heads in the southern well groups are lower than in the trough-like cone of depression immediately to the north (fig. 22), indicating that natural or commingled well leakage might be allowing flow to pass through the possible horizontal flow barrier between group 12 (gray squares) and group 13 (red diamonds) (figs. 15 and 19). The complexity in flow near group 13 is further illustrated by the hydraulic head patterns of groups 13 and 14 (figs. 19 and 20G-I). Despite the fact that group 14 may be divided into two groups with apparently distinct behavior, groups 14-1 (white diamonds) and 14-2 (black diamonds) cannot be separated laterally or into shallow and deep groups, although each of these groups show similar post-1980 characteristics with various group 13 wells (igs. 19 and $\underline{20 \mathrm{H}}-\underline{\mathrm{I}}$ ). 


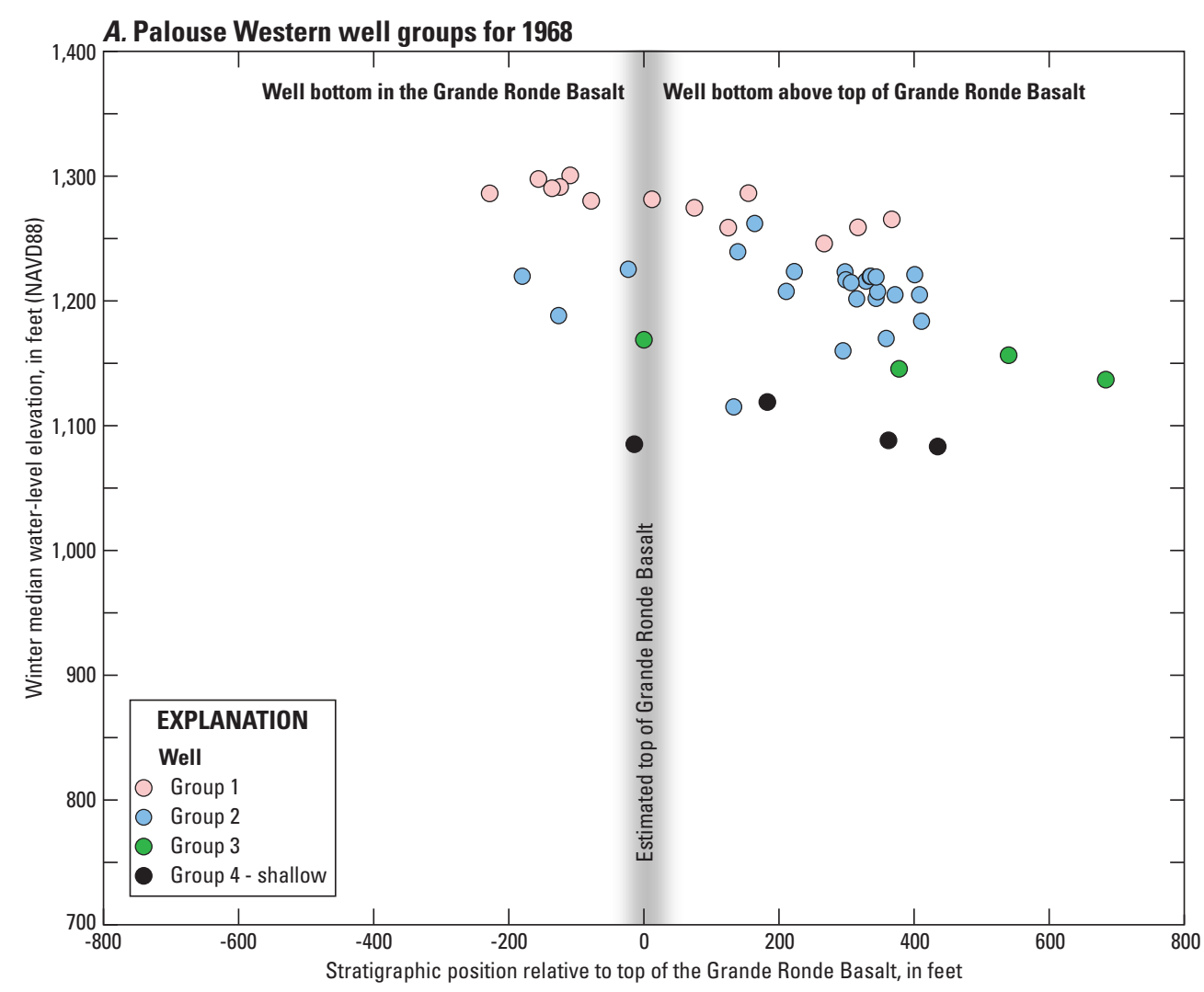

Figure 20. Distance of the well bottom from the simulated top of Grande Ronde Basalt compared with water levels measured in wells near the Washington State Department of Ecology administrative areas in parts of the Palouse Slope/eastern Yakima Fold Belt and the Columbia Basin Ground Water Management Area, Washington. Palouse western well group for $(A)$ 1968; $(B)$ 1984; $(C)$ 2006; Palouse eastern well group for $(D)$ 1968; (E) 1984; (F) 2006; and Palouse southern well group for $(G)$ 1968; $(H)$ 1984; and $(I)$ 2006. Locations of groups are shown in figure 15. 

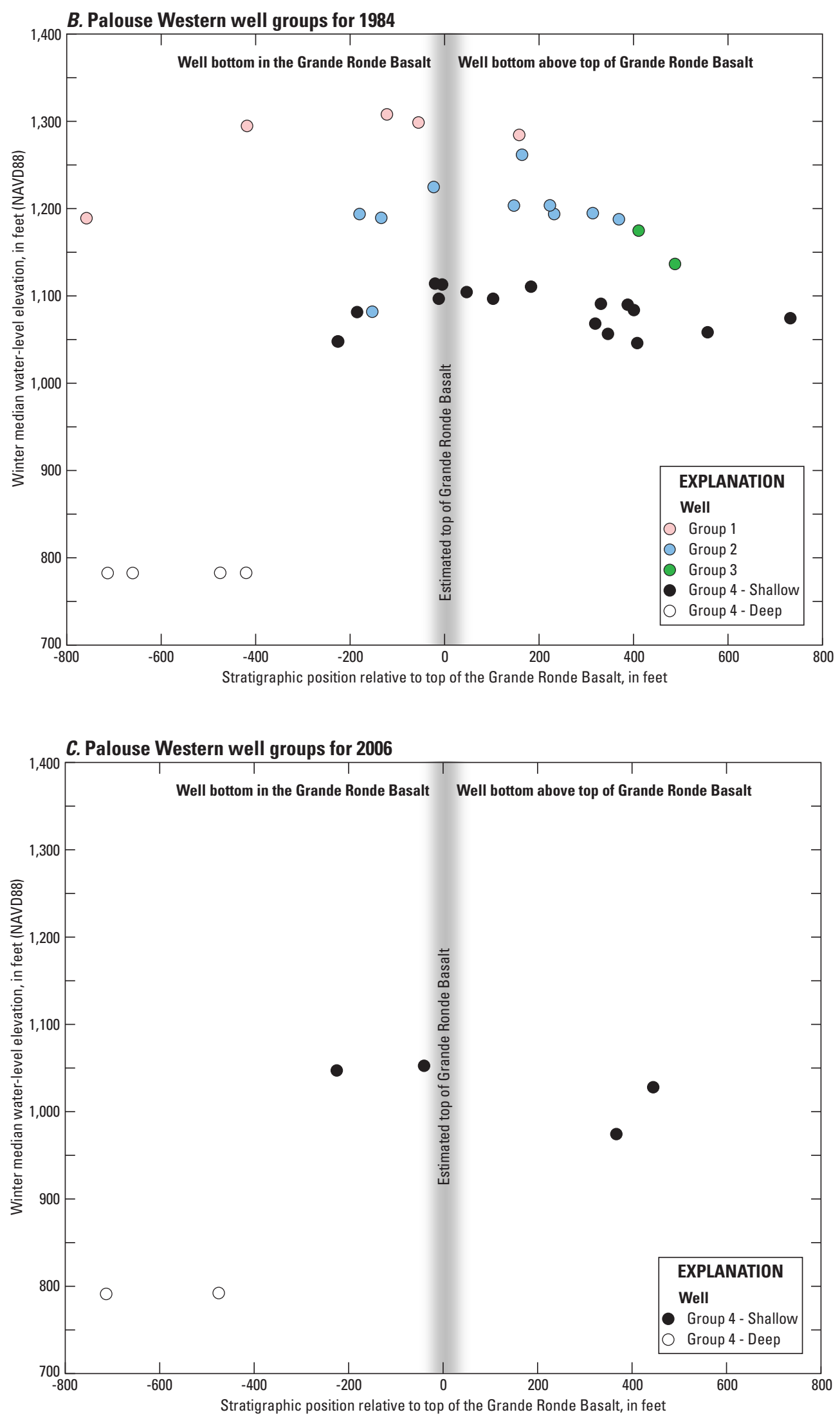

Figure 20.-Continued 

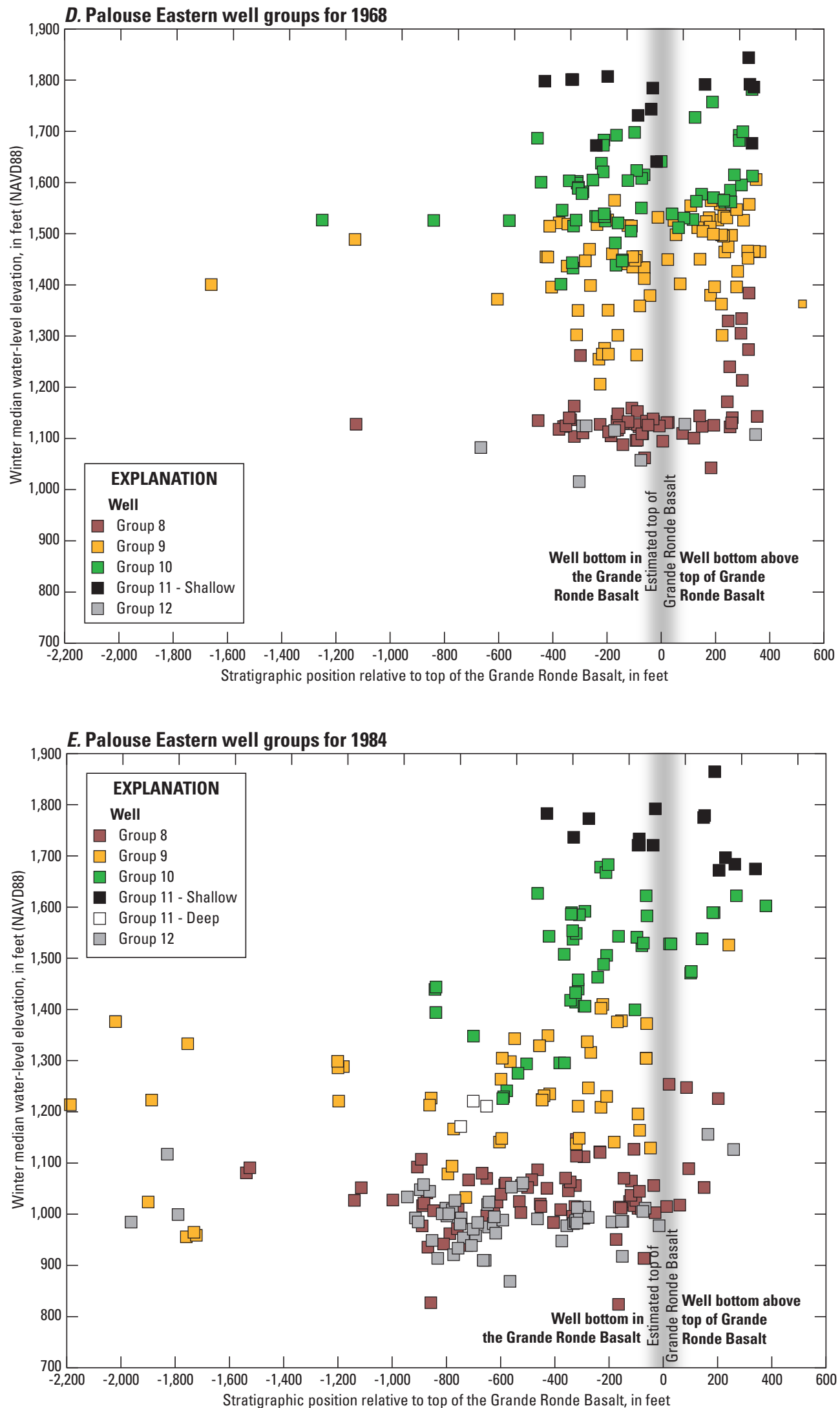

Figure 20.-Continued 

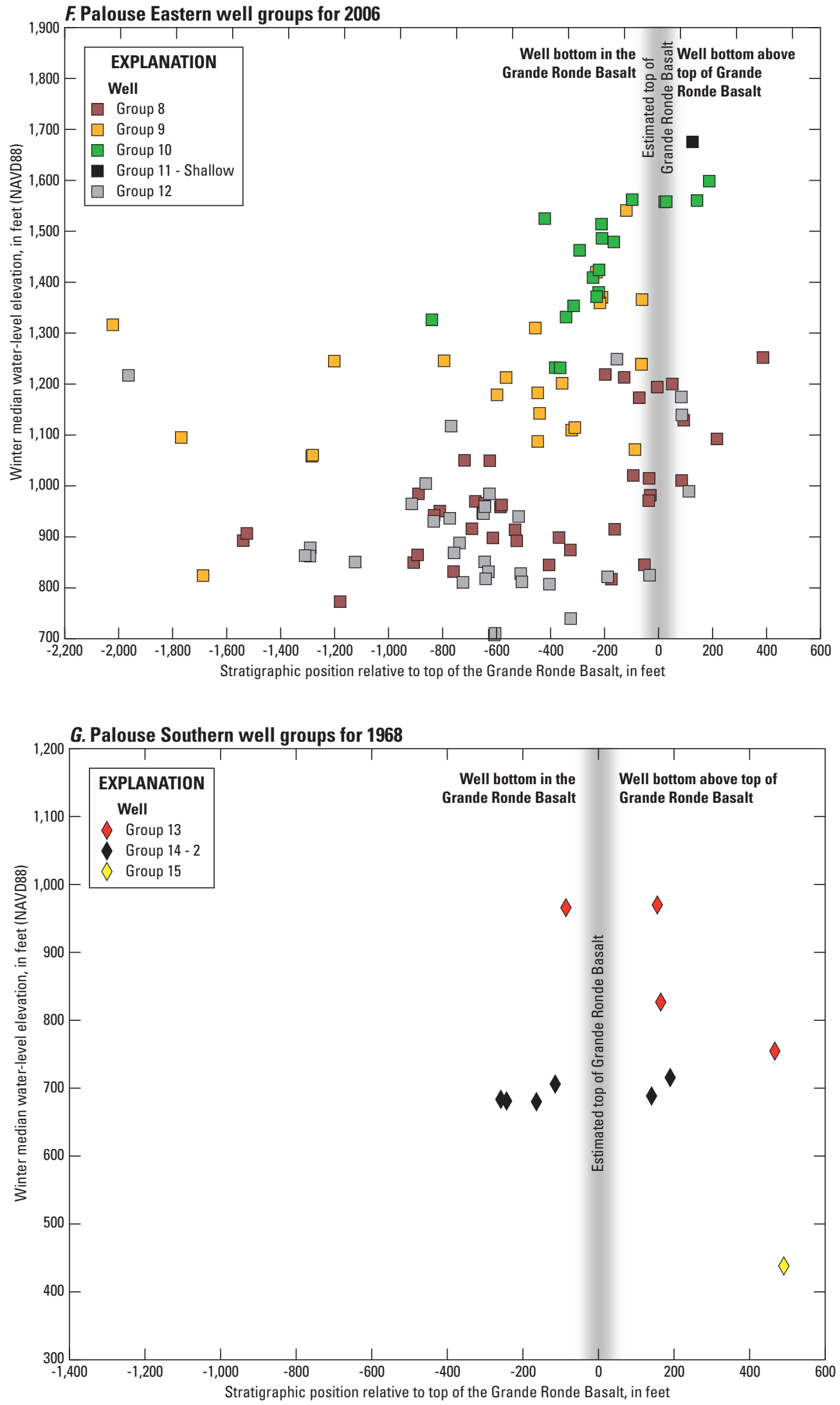

Figure 20.-Continued 

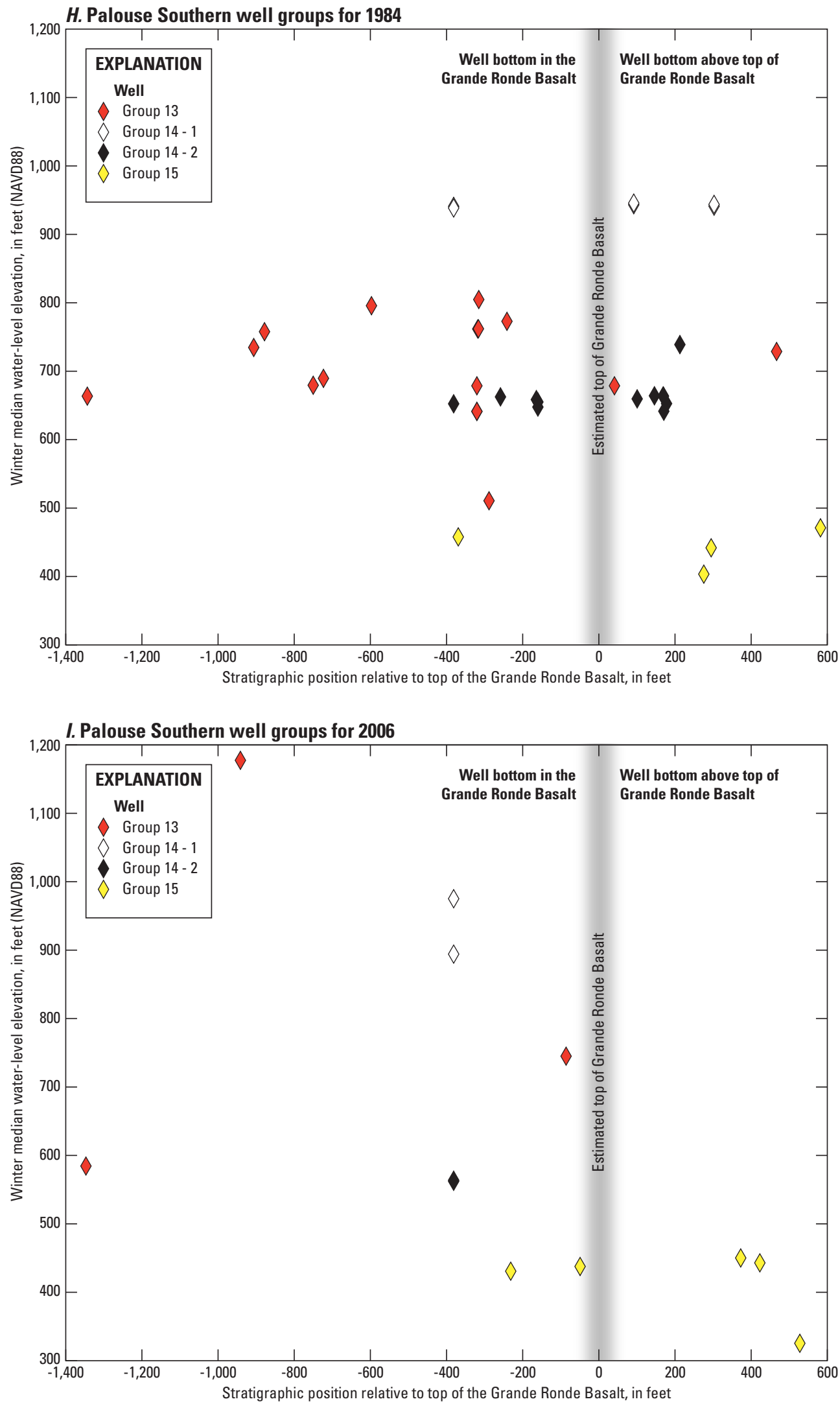

Figure 20.-Continued 


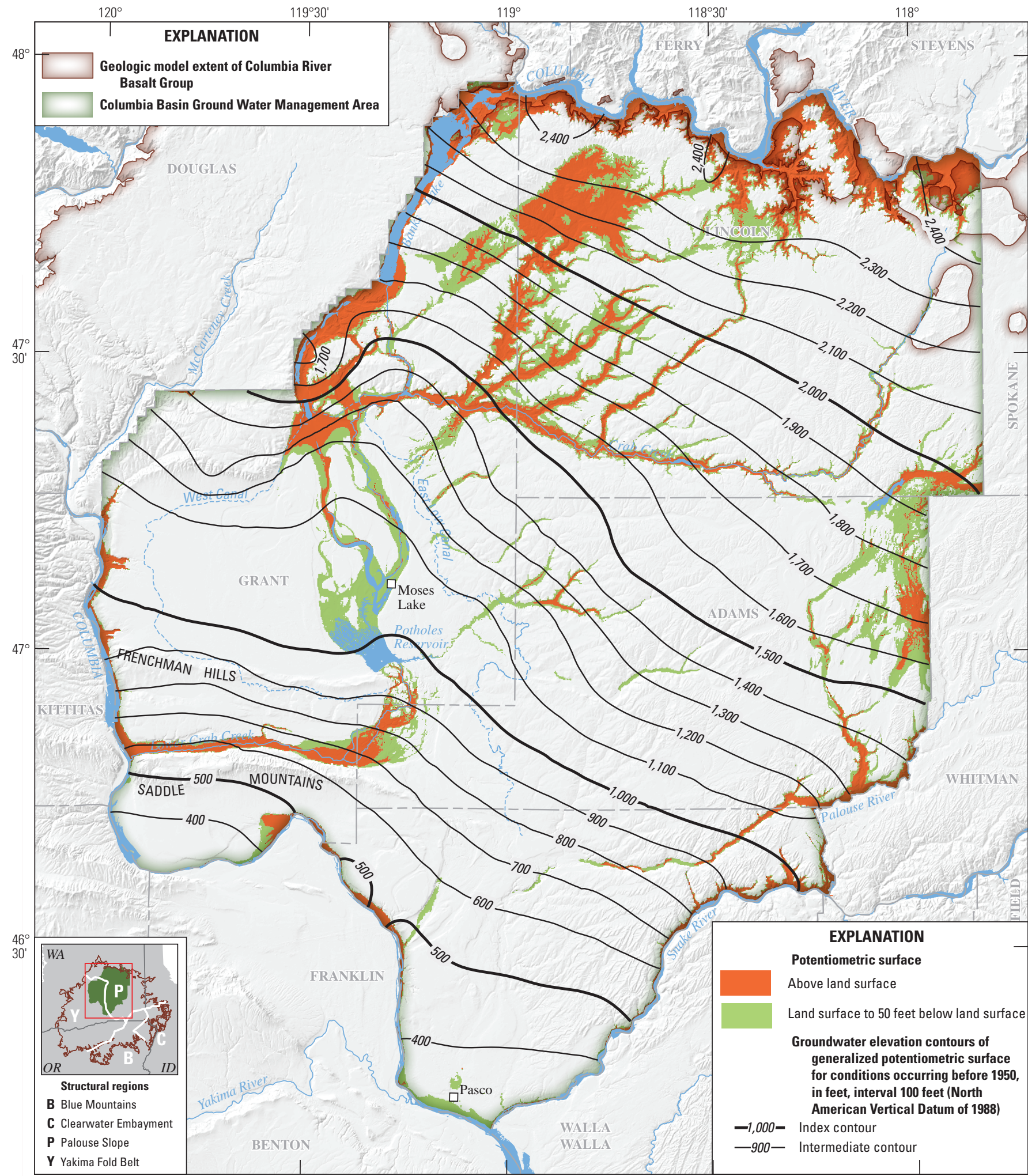

Base map modified from USGS and other digital data, various scales. Coordinate system: State Plane-Washington South FIPS 4602, Projection: Lambert Conformal Conic; North American Datum of 1983.

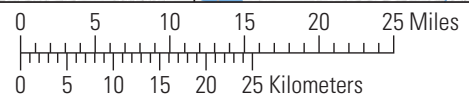

Figure 21. Generalized potentiometric surface for measured Columbia River Basalt Group aquifer conditions during the predevelopment period in parts of the Palouse Slope/eastern Yakima Fold Belt and the Columbia Basin Ground Water Management Area, Washington. Areas where potentiometric surface is above or near land surface indicate greater potential for groundwater discharge to coulees prior to substantial groundwater declines. 


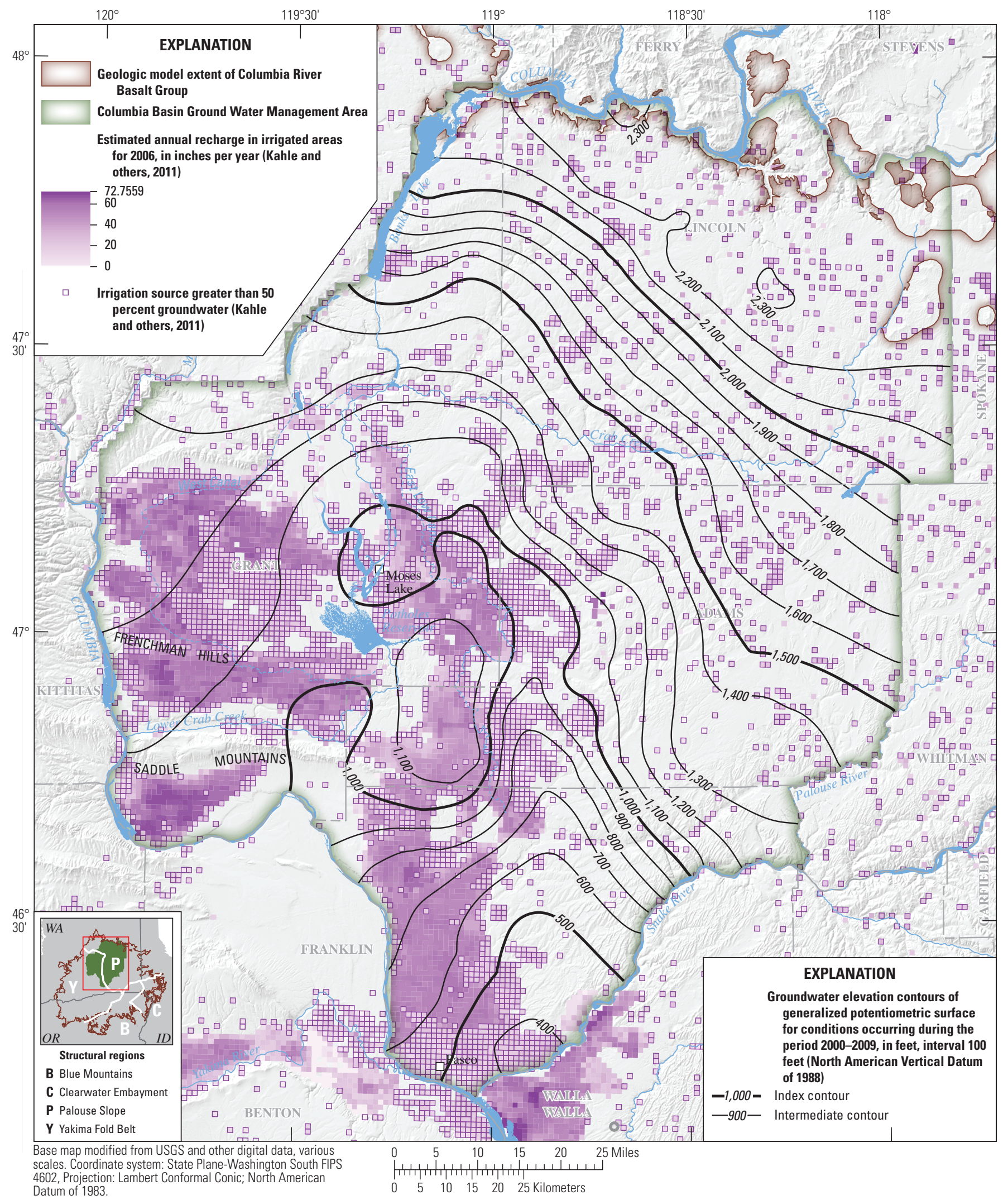

Figure 22. Generalized potentiometric surface for measured Columbia River Basalt Group aquifer conditions during 2000-2009 in parts of the Palouse Slope/eastern Yakima Fold Belt and the Columbia Basin Ground Water Management Area, Washington. 
The central Palouse Slope shows a general lack of geologic structure or other evidence for strong horizontal flow barriers to the east, but the east-west trending faults associated with the ridges between the western valleys (the Frenchman Hills and the Saddle Mountains) in the eastern Yakima Fold Belt are likely barriers to flow. Luzier and Burt (1974) identified a "groundwater dam" on the Palouse Slope extending from the northwest to the southeast through the junction of Adams, Grant, and Lincoln Counties that is associated with an apparent change in hydraulic gradient (this feature is only partially represented because of the general nature of the smoothed potentiometric maps shown in figures 21 and 22). This steeper hydraulic gradient also was identified in this analysis at the boundary between group 9 (orange squares) and group 8 (brown squares) of the eastern well groups (figs. 15 and 17) and was present at least as early as 1940 prior to substantial water deliveries from the Columbia Basin Project, which began in the 1950s. One of the few locations with persistent bias in the residuals for the pre-development potentiometric surface was in the area where group 9 hydraulic heads were simulated as too high, indicating a local steepening of the hydraulic gradient to the east, and a flattening to the west. The flattening of water levels is evident in group 8 in 1968 (fig. 20D). As an alternative to the groundwater dam proposed by Luzier and Burt (1974), this steepened hydraulic gradient is hypothesized to result from a complex discharge boundary where the upper aquifers are intersected at land surface by incised canyons, which allows water to flow into the sediment-filled coulees. The potential for this outflow is indicated by the pre-development generalized potentiometric surface above or near the land surface in the coulees (fig. 21). Incision of the coulees into the Wanapum Basalt geologic unit (fig. 2) is sufficient that several lava flows and potentially several aquifers in the Wanapum Basalt may be intersected (Burns and others, 2011), possibly forming pathways for groundwater flow that would result in complex head patterns (not shown in figure 21) and apparent alterations in the regional hydraulic gradient. Most late-time (2000-2010) hydraulic heads are now below the elevation of the coulees, indicating that groundwater discharge to the coulees has declined over time. Two additional pieces of evidence support the hypothesis that groundwater historically discharged in this location. First, because shallow aquifers tend to drain into the coulees possibly dewatering parts of these aquifers, fewer wells are completed in the aquifers intersecting the coulees along a north-south swath in this area. Second, the apparently random highly variable heads about 300-400 ft above the Grande Ronde Basalt geologic model unit (approximate elevation of Wanapum Basalt intersected by the coulees) and flattening of the water levels below this stratigraphic elevation are characteristic of a highly variable flow field where groundwater is flowing to local drainage features (compare group 8 [brown squares] wells in figure 20D to hypothetical well groups in figure A2B and the associated discussion). The lowest land-surface elevation in the coulees where the potentiometric surface is above land surface is the controlling aquifer drainage elevation. This elevation is about $1,180 \mathrm{ft}$, which is the approximate inflection point of group 8 wells in 1968 (fig. 20D).

\section{Summary and Conclusions}

The Columbia Plateau Regional Aquifer System (CPRAS) covers an area of about 44,000 square miles in a structural and topographic basin within the drainage of the Columbia River in Washington, Oregon, and Idaho. The primary aquifers occur in basalts of the Columbia River Basalt Group (CRBG) and in places, overlying sediment. The system consists of a series of productive basalt aquifers within permeable interflow zones separated by less permeable flow interiors, overlaid locally by aquifers within sedimentary deposits. Groundwater levels have declined throughout much of the CPRAS since the 1970s.

Information was compiled from about 60,000 wells and 450,000 water-level measurements from wells in the CPRAS. Data are from an inventory of published and unpublished well data from many agencies. A subset of these data for the CRBG aquifer wells were used to develop a simple linear groundwater-level trend map for 1968-2009, which illustrates a persistent pattern of widespread groundwater-level declines. Overall declines from the analysis of data from 761 wells in the CRBG aquifers were measured in 72 percent of the wells. The mean of the trends was a decline of 1.9 feet per year ( $\mathrm{ft} / \mathrm{yr}$ ). Rates of declines greater than $1.0 \mathrm{ft} / \mathrm{yr}$ were measured in 50 percent of wells, declines greater than $2.0 \mathrm{ft} / \mathrm{yr}$ in 38 percent of wells, declines greater than $4.0 \mathrm{ft} / \mathrm{yr}$ in 29 percent of wells, declines greater than $6.0 \mathrm{ft} / \mathrm{yr}$ in 9 percent of wells, and rates of decline greater than $8.0 \mathrm{ft} / \mathrm{yr}$ in 4 percent of wells.

The groundwater-level data also were used to identify groups of wells with similar hydraulic heads and temporal trends within limited subregions. Comparisons between adjacent well groups were used to define sets of well groups that delineate areas of overall similar groundwater-flow conditions. Discontinuities in hydraulic head between the sets of well groups were used to help infer the presence of barriers to groundwater flow. These barriers can include geologic features that influence the hydraulic properties of the aquifer, such as changes in lithology or the occurrence of folds and faults. In areas without flow barriers, dissimilarities in response of well groups over time result from the formation of irrigation-derived groundwater mounds or pumping induced regions of decline. The areas of focus for this analysis included the Umatilla area, Oregon, and the Palouse Slope/ eastern Yakima Fold Belt (eYFB) in the Columbia Basin Ground Water Management Area (GWMA) consisting of Adams, Franklin, Grant, and Lincoln Counties, Washington. 
In the Umatilla area, 286 wells were divided into groups with similar water levels and trends, and large hydraulic gradients between nearby groups defined barriers to groundwater flow. The barriers divide the groundwater-flow system in the Umatilla area into several leaky compartments that occur in vertical and horizontal directions. However, the degree of leakiness is highly variable. Significant findings for the Umatilla area include:

- Most CRBG aquifers are declining, except for a few shallow aquifers. Cumulative declines range from 100 to 300 feet since 1970 .

- High horizontal hydraulic gradients and differences in temporal trends in water levels between adjacent well groups define horizontal flow barriers that generally correspond to mapped geologic structural features. Horizontal hydraulic gradients increase from north to south, which generally corresponds to an increase in structural complexity. This implies that recharge from the uplands into the heavily developed areas may be impeded.

- Significant vertical hydraulic gradients have been documented in a relatively small part of the Umatilla area, where the shallow aquifer system is distinct from the deep system. Since the 1970s, downward vertical gradients in these areas have been increasing as water-level declines have occurred in deeper wells due to pumping and commingling of these aquifers. Because the geology generally is conducive to creating vertical hydraulic gradients, the absence of vertical gradients over much of the area may be a consequence of flow through commingling wells resulting in the equilibration of the heads in the aquifers.

In the Palouse Slope of the central GWMA, the largest declining groundwater-level trends (1968-2009) follow a general north-south line through the middle of the GWMA. An analysis of 1,195 wells along major flow paths and through the area of persistent groundwater-level declines indicates that barriers to flow are not as evident in this area as near Umatilla, but well groups were still identifiable based on similar hydraulic heads and response to hydraulic stresses. This is consistent with the geologic interpretation of the Palouse Slope as being a gently folded structure created during subsidence when CRBG lavas were deposited in voluminous sheet flows. In this area, hydrographs of well groups were viewed along general flow paths that have developed as the result of irrigation stresses on the aquifer system.

Significant findings for the Palouse Slope/eYFB include:

- Groundwater levels in CRBG aquifers have risen since the 1950s in areas heavily irrigated with surface water and have declined since the 1970s in areas commonly irrigated with groundwater. For wells examined, typical rises in water level under surface-water irrigation areas are about 50 feet, with larger rises occurring locally (for example, in the fault bounded valleys to the south of the Frenchman Hills and the Saddle Mountains). Cumulative declines of 200 feet or greater are common in areas where pumping groundwater is the dominant source of irrigation water.

- Horizontal flow barriers are less apparent in this area than in the Umatilla area.

- Data indicate that significant vertical hydraulic gradients still exist, although much of the aquifer thickness is affected by commingling of wells.

- Prior to development, groundwater flow was from the uplands toward the Columbia and Snake Rivers. Late-time (2000-2010) flow patterns in the area are substantially altered by largescale irrigation recharge and pumping patterns, and in some cases are reversed relative to predevelopment conditions.

- The effect of commingling of water from multiple aquifers and its relative contribution to groundwater-level declines is not clear from these data; however, groundwater-flow modeling currently under development as part of the overall study may aid in quantifying these effects.

- The presence of a groundwater discharge boundary, where the upper aquifers are intersected at land surface by incised canyons and groundwater flows into the sediment-filled coulees, is an alternative to the hypothesis of a groundwater dam to explain local steepening of the hydraulic gradient along the Palouse Slope. 
The use of stratigraphic coordinates to identify aquifers with similar water levels and trends worked well in the analysis of the groundwater conditions for the Umatilla area and Palouse Slope/eYFB. This suggests a way to advance the understanding of the geometry of local and regional aquifers by using the elevations of well bottoms for groups of wells with similar water levels and trends. This technique may be used to help identify the influence (or lack of influence) of structural features on groundwater flow or even to infer where previously unmapped structural features may exist. Trend surfaces representing aquifers and lava flow top elevations may be mapped in many areas across the Columbia Plateau, refining the current understanding of major geologic formations into smaller hydraulically important units.

\section{Acknowledgments}

The authors thank the many people who contributed their time and knowledge to help complete this study. The following organizations are noted for their special assistance with the collection of data: Columbia Basin Ground Water Management Area, Confederated Tribes of the Umatilla Indian Reservation, GSI Water Solutions, Inc., Oregon Water Resources Department, U.S. Department of Energy, Walla Walla Basin Watershed Council, and Washington State Department of Ecology. The following USGS employees are gratefully acknowledged for their contributions to the study: Danial Polette and Leonard Orzol assisted with analysis of the data; Fred Tillman developed and modified Excel ${ }^{\circledR}$ spreadsheet tools that greatly simplified the processing of the data; Sue Kahle and Marshall Gannett provided guidance and insights; and the many other USGS employees whose everyday efforts go to support this and many other studies.

\section{Selected References}

(Bold text indicates reference is cited in report.)

Bauer, H.H., and Hansen, A.J., 2000, Hydrology of the Columbia Plateau regional aquifer system, Washington, Oregon, and Idaho: U.S. Geological Survey WaterResources Investigations Report 96-4106, 61 p. (Also available at http://pubs.er.usgs.gov/usgspubs/wri/ wri964106.)
Burns, E .R ., M organ, D.S., Lee, K.K., H aynes, J .V., and C onlon, T.D., 2012, E valuation of long-term waterlevel declines in basalt aquifers near M osier, O regon: U.S. Geological Survey Scientific Investigations Report 2012-5002, 134 p. (Also available at http://pubs.er.usgs. gov/publication/sir20125002.)

Burns, E .R., M organ, D.S., Peavler, R .S., and K ahle, S.C., 2011, Three-dimensional model of the geologic framework for the Columbia Plateau Regional Aquifer System, Idaho, Oregon, and Washington: U.S. Geological Survey Scientific Investigations Report 20105246, 44 p. (Also available at http://pubs.er.usgs.gov/ publication/sir20105246.)

Cleveland, W.S., Grosse, E., and Shyu, W.M., 1992, Local regression models, chap. 8 of Chambers, J.M., and Hastie, T.J., eds., Statistical models in S: Pacific Grove, Calif., Wadsworth and Brooks/Cole Advanced Books and Software, p. 309-376.

Drost, B.W., Whiteman, K.J., and Gonthier, J.B., 1990, Geologic framework of the Columbia Plateau Aquifer System, Washington, Oregon, and Idaho: U.S. Geological Survey Water-Resources Investigations Report 87-4238, 10 p., 10 sheets. (Also available at http://pubs.er.usgs.gov/usgspubs/wri/wri874238.)

Kahle, S.C., Morgan, D.S., Welch, W.B., Ely, D.M., Hinkle, S.R., Vaccaro, J J ., and O rzol, L .L ., 2011, H ydrogeologic framework and hydrologic budget components of the Columbia Plateau Regional Aquifer System, Washington, Oregon, and Idaho: U.S. Geological Survey Scientific Investigations Report 2011-5124, 66 p. (Also available at http://pubs.er.usgs.gov/publication/ sir20115124.)

Kahle, S.C., Olsen, T.D., and Morgan, D.S., 2009, Geologic setting and hydrogeologic units of the Columbia Plateau Regional Aquifer System, Washington, Oregon, and Idaho: U.S. Geological Survey Scientific Investigations Map 3088, 1 sheet. (Also available at http://pubs.er.usgs. gov/usgspubs/sim/sim3088.)

Keys, M.E., Vaccaro, J.J., Jones, M.A., and Julich, R.J., 2008, Hydrographs showing ground-water level trends for selected wells in the Yakima River basin aquifer system, Washington: U.S. Geological Survey Data Series 343. (Also available at http://pubs.er.usgs.gov/ publication/ds343.) 
Lindolm, G.F., and Vaccaro, J.J., 1988, Region 2, Columbia Lava Plateau, chap. 5 of Back, William, Rosenshein, J .S., and Seaber, P.R ., eds., H ydrogeology: Boulder, Colo., Geological Society of America, The Geology of North America, v. 0-2, p. 37-50, accessed June 27, 2012, at http://www.clemson.edu/ces/hydro/murdoch/Courses/ Aquifer \%20Systems/documents/Heath\%20and $\% 20$ Back\%20books/Chapter\%205.pdf.

Luzier, J.E., and Burt, R.J., 1974, Hydrology of basalt aquifers and depletion of ground water in east-central Washington: Washington State Department of Ecology, Water-Supply Bulletin 33, 53 p., accessed June 27, 2012, at http://www.ecy.wa.gov/programs/eap/wsb/wsb_All. html\#p33.

Newcomb, R.C., 1959, Some preliminary notes on ground water in the Columbia River Basalt: Northwest Science, v. 33, no. 1, p. 1-18, accessed June 27, 2012, at http:// www.vetmed.wsu.edu/org_NWS/NWSci\%20journal\%20 articles/1950-1959/1959\%20vol\%2033/33-1/v33\%20 p1\%20Newcomb.PDF.

Oregon Water Resources Department, 2012, Water protections and restrictions: Oregon Water Resources Department Web site, accessed July 11, 2012, at http:// www.oregon.gov/OWRD/PUBS/aquabook_protections. aspx.

Porcello, J.J., Tolan, T.L., and Lindsey, K.A., 2009, G roundwater level declines in the Columbia R iver Basalt Group and their relationship to mechanisms for groundwater recharge-A conceptual groundwater system model, Columbia Basin Ground Water Management Area of Adams, Franklin, Grant, and Lincoln Counties: Othello, Wash., prepared by the Columbia Basin Ground Water Management Area of Adams, Franklin, Grant, and Lincoln Counties, June 2009, 175 p., accessed June 27, 2012, at http://www. cbgwma.org/pdf/GWMA_Groundwater\%20Level\%20 Declines_\%20TEXT_June\%202009.pdf.

Reidel, S.P., Johnson, V.G., and Spane, F.A., 2002, Natural gas storage in basalt aquifers of the Columbia Basin, Pacific Northwest USA-A guide to site characterization: Pacific Northwest National Laboratory, Richland, Washington, 277 p., accessed June 27, 2012, at http://www.pnl.gov/main/publications/ external/technical_reports/PNNL-13962.pdf.
Senay, G .B ., B udde, M ichael, Verdin, J .P., and M elesse, A.M., 2007, A coupled remote sensing and simplified surface energy balance approach to estimate actual evapotranspiration from irrigated fields: Sensors, v. 7, p. 979-1000, accessed September 27, 2012, at http://dx.doi. org/10.3390/s7060979.

Snyder, D.T., 2008, Estimated depth to ground water and configuration of the water table in the Portland, Oregon area: U.S. Geological Survey Scientific Investigations Report 2008-5059, 40 p. (Also available at http://pubs. er.usgs.gov/publication/sir20085059.)

Snyder, D.T., and Haynes, J .V., 2010, G roundwater conditions during 2009 and changes in groundwater levels from 1984 to 2009, Columbia Plateau Regional Aquifer System, Washington, Oregon, and Idaho: U.S. Geological Survey Scientific Investigations Report 20105040, 12 p. (Also available at http://pubs.er.usgs.gov/ publication/sir20105040.)

Sokol, Daniel, 1963, Position and fluctuations of water level in wells perforated in more than one aquifer: Journal of Geophysical Research, v. 68, no. 4, p. 1079-1080, accessed June 27, 2012, at http://onlinelibrary.wiley.com/ doi/10.1029/JZ068i004p01079/abstract.

Swanson, D.A., Wright, T.L., Hooper, P.R., and Bentley, R.D., 1979, Revisions in the stratigraphic nomenclature of the Columbia River Basalt Group: U.S. Geological Survey Bulletin 1457-G, 59 p. (Also available at http:// pubs.er.usgs.gov/publication/b1457G.)

Taylor, C.J., and Alley, W.M., 2002, Ground-water-level monitoring and the importance of long-term water-level data: U.S. Geological Survey Circular 1217, 68 p. (Also available at http://pubs.er.usgs.gov/publication/cir1217.)

TIBCO Software, Inc., 1988-2008, Spotfire $\mathbf{S}+\mathbf{8 . 1}$ for Windows: Somerville, Mass., accessed August 28, 2012, at http://spotfire.tibco.com/products/s-plus/statisticalanalysis-software.aspx.

Tillman, F.D., 2009, Excel® spreadsheet tools for analyzing groundwater level records and displaying information

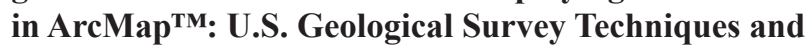
Methods 4-F1, 59 p. (Also available at http://pubs. er.usgs.gov/publication/tm4F1.) 
Tolan, T.L., Reidel, S.P., Beeson, M.H., Anderson, J.L., Fecht, K.R., and Swanson, D.A., 1989, Revisions to the estimates of the areal extent and volume of the Columbia River Basalt Group, in Reidel, S.P., and Hooper, P.R., eds., Volcanism and tectonism in the Columbia River flood-basalt province: Geological Society of America Special Paper 239, p. 1-20.

U.S. C ensus Bureau, 2000, Census 2000 gateway: U.S. Census B ureau database, accessed J uly 6, 2012, at http:// www.census.gov/main/www/cen2000.html.

U.S. Geological Survey, 1999, National Elevation Dataset: U.S. Geological Survey Fact Sheet 148-99, 2 p. (Also available at http://erg.usgs.gov/isb/pubs/factsheets/ fs14899.html.)

U.S. Geological Survey, 2008, Ground-Water availability assessment for the Columbia Plateau Regional Aquifer System, Washington, Oregon, and Idaho: U.S. Geological Survey Fact Sheet 2008-3086, 2 p. (Also available at http:// pubs.er.usgs.gov/usgspubs/fs/fs20083086.)

U.S. Geological Survey, 2012, A three-dimensional hydrogeologic framework model of Columbia Plateau Regional Aquifer System: U.S. Geological Survey database, accessed J uly 2, 2012, at http://or.water.usgs. gov/proj/cpras/index.html.

Vaccaro, J.J., 1999, Summary of the Columbia Plateau Regional Aquifer-System analysis, Washington, Oregon, and Idaho: U.S. Geological Survey Professional Paper 1413-A, 51 p. (Also available at http://pubs.er.usgs.gov/ usgspubs/pp/pp1413A.)

Vaccaro, J.J., Jones, M.A., Ely, D.M., Keys, M.E., Olsen, T.D., Welch, W.B., and Cox, S.E., 2009, Hydrogeologic framework of the Yakima River basin aquifer system, Washington: U.S. Geological Survey Scientific Investigations Report 2009-5152, 106 p. (Also available at http://pubs.er.usgs.gov/usgspubs/sir/sir20095152.)
Washington State Department of Ecology, 1988a, Columbia Basin Project-Ground Waters: Washington Administrative Code, Ecology Edition, Chap. 508-14 WAC, last updated June 9, 1988, 4 p., accessed June 27, 2012, at http://www.ecy.wa.gov/pubs/wac50814.pdf.

Washington State Department of Ecology, 1988b, Odessa ground water management subarea: Washington Administrative Code, Ecology Edition, Chap. 173-128A WAC, last updated June 9, 1988, 4 p., accessed June 27, 2012, at http://www.ecy.wa.gov/pubs/wac173128a.pdf.

Washington State Department of Ecology, 1988c, Quincy ground water management subarea and zones: Washington Administrative Code, Ecology Edition, Chap. 173-124 WAC, last updated June 9, 1988, 4 p., accessed June 27, 2012, at http://www.ecy.wa.gov/pubs/ wac173124.pdf.

Whiteman, K.J., 1986, Ground-water levels in three basalt hydrologic units underlying the Columbia Plateau, Washington and Oregon, spring 1984: U.S. Geological Survey Water-Resources Investigations Report 86-4046, 4 sheets. (Also available at http://pubs.er.usgs.gov/ usgspubs/wri/wri864046.)

Whiteman, K.J., Vaccaro, J.J., Gonthier, J.B., and Bauer, H.H., 1994, Hydrogeologic framework and geochemistry of the Columbia Plateau regional aquifer system: U.S. Geological Survey Professional Paper 1413-B, 73 p. (Also available at http://pubs.er.usgs.gov/usgspubs/pp/ pp1413B.) 
This page intentionally left blank. 


\section{Appendix A. Interpretation Guide for Graphs of Stratigraphic Position Compared with Hydraulic Head for Wells in the Columbia River Basalt Group, Washington, Oregon, and Idaho}

After wells have been grouped into spatial clusters based on similar values of head and similar trends, the variability within each group may be examined to evaluate vertical hydraulic gradients. This is accomplished by plotting all available head data collected during a short period (relatively unaffected by temporal trends) as a function of the stratigraphic position of the aquifer being measured. If the vertical head gradients are large relative to the slope of the potentiometric surface within each aquifer, then the vertical gradient is apparent.

The assignment of hydraulic head values to a given stratigraphic position is fraught with complications that may affect the accuracy of any single data point. For Columbia River Basalt Group (CRBG) wells, it is assumed that the well terminates in a productive aquifer, and that the measured head in that well is representative of an aquifer at that stratigraphic position. Stratigraphic position is computed as the difference between the elevation of the bottom of the well and an estimate of the elevation of a geologic horizon that originally was flat. Use of stratigraphic position removes the influence of dipping, folding, and faulting when correlating strata that can act as laterally continuous aquifers. Conversely, in areas where CRBG units are discontinuous or exhibit significant thinning or thickening, stratigraphic position may have a spatial trend. As long as the group of wells being examined does not cover too large an area, spatial bias of stratigraphic position generally will be small. In addition to this complication, well commingling can result in hydraulic head measurements that are not representative of the aquifer at the well bottom (for example, well 1 in fig. 6).
Despite the potential complications, combinations of persistent patterns in stratigraphic position and hydraulic head may be interpreted hydrologically (fig. A1). The clustering of wells at distinct stratigraphic positions is evidence that distinct aquifers are locally important, and when hydraulic heads are distinctively different between aquifers, downward (fig. A1A) and upward (ig. A1B) vertical gradients exist. Similarly, there may be multiple distinct aquifers with no vertical gradient (fig. A1C). For the CRBG, significant vertical distance between two distinct aquifers implies the presence of a potential confining unit and the likelihood that a vertical hydraulic gradient should exist. However, aquifers may be hydraulically connected naturally through complex CRBG geometry, or they may be connected through commingling wells. If historical evidence supports a significant vertical gradient (ig. $\mathrm{A} 1 \mathrm{~A}-\underline{\mathrm{B}})$, but recent measurements are consistently similar for each aquifer (fig. A1C), then commingling wells are the likely cause.

For many areas in the Columbia Plateau Regional Aquifer System (CPRAS), the repeating sequence of CRBG interflows and flow interiors results in a continuum of stratigraphic position (fig. A1D). In this case, there is either a single aquifer or many thin aquifers, and there can be downward, upward, or no significant vertical gradient present. For most areas within the CPRAS, vertical gradients are expected, so no vertical gradient over several hundred feet of stratigraphic position (fig. A1D) indicates that aquifers likely are hydraulically connected either naturally or through commingling wells. 


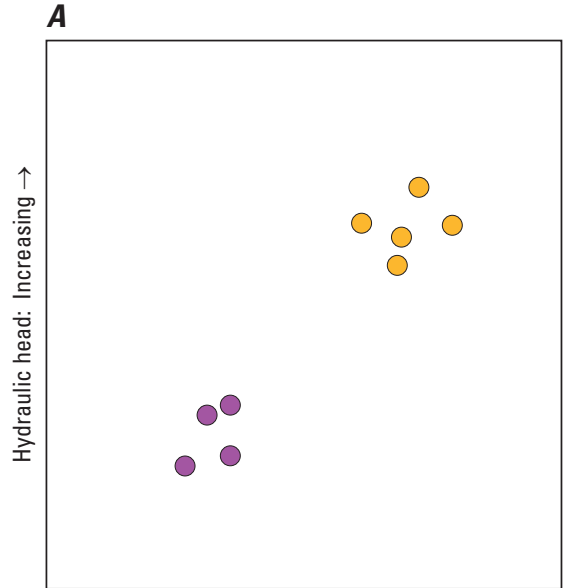

Stratigraphic position: Increasing $\rightarrow$

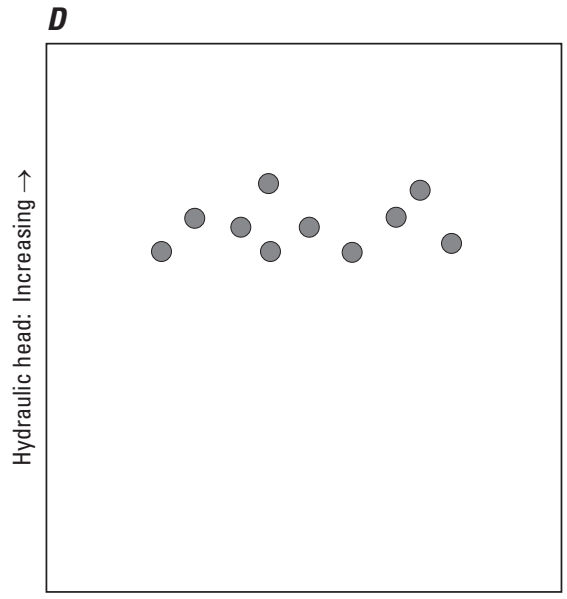

Stratigraphic position: Increasing $\rightarrow$

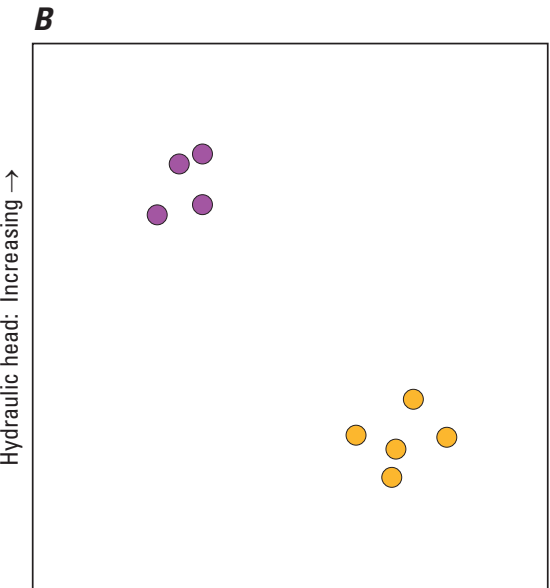

Stratigraphic position: Increasing $\rightarrow$

\section{$\boldsymbol{E}$}

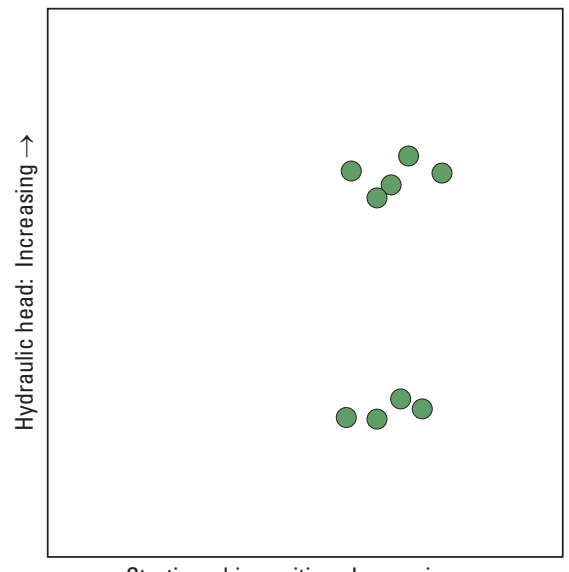

C

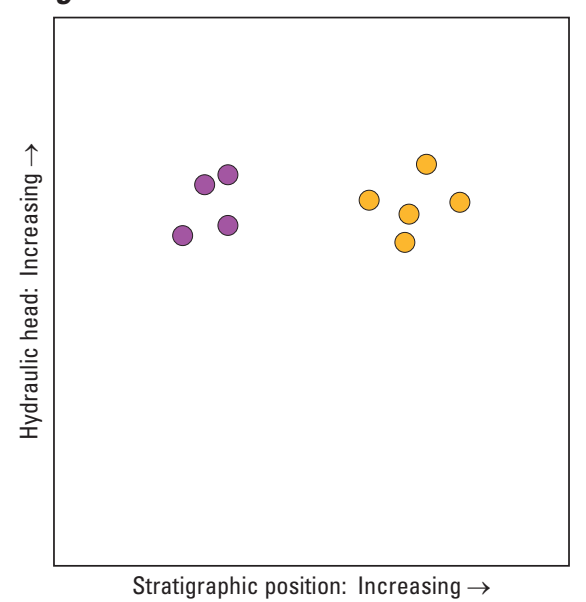

F

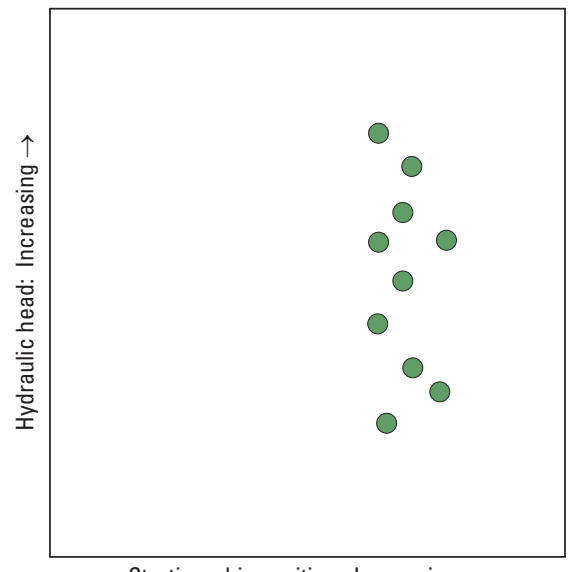

Stratigraphic position: Increasing $\rightarrow$

Figure A1. Expected patterns of hydraulic head as a function of stratigraphic position. $(A)$ Two distinct aquifers with a significant downward hydraulic gradient; $(B)$ two distinct aquifers with a significant upward gradient; $(C)$ two distinct aquifers with no significant vertical gradient $(D)$ a single thick aquifer or multiple thin aquifers with no significant vertical gradient; $(E)$ a single aquifer with (apparently) two distinctly different hydraulic heads; and ( $F$ a single aquifer with an apparent continuum of heads. 
During the process of creating spatial clusters of wells, two distinctly different heads at the same stratigraphic position (fig. A1E) potentially signals the presence of a horizontal barrier to groundwater flow. If all higher head wells are in a separate location from the lower head wells, then some barrier to flow may exist, and the wells would be divided into separate groups. If the high and low head wells appear to be randomly mixed spatially, then well construction, pumping from adjacent wells, or geologic heterogeneity are the likely causes of the pattern (fig. 6). If a continuum of heads exist within a single aquifer (fig. A1F), then additional explanations may include a steep regional gradient of the potentiometric surface, or local perturbations to the potentiometric surface that may occur in the presence of groundwater discharge boundaries (such as incised canyons with springs and seeps). These local and regional effects may be separated by removing the regional trend from the potentiometric surface and examining the range of the residual heads.
Combinations of expected patterns of hydraulic head as a function of stratigraphic position (figs. A1A- F). are frequent in the real data for CRBG wells as illustrated in figures 12A-F and 20A-1. Over time, new deep wells have increasingly been required to case and seal to the aquifer, hydraulically isolating these wells from the upper commingled aquifers. Whereas the upper aquifers frequently have fairly uniform hydraulic heads, the deeper aquifers have a distinctly different head (compare fig. A2A to group 4 shallow and deep wells [black circles and white circles] shown in figure $20 \mathrm{~B}-\underline{\mathrm{C}}$ and to group 11 shallow and deep wells [black squares and white squares] in fig. 20E). A continuum of heads associated with local groundwater drainage of upper aquifers may be combined with a uniform vertical gradient for deep aquifers (fig. A2B) to provide the observed pattern of group 8 wells (brown squares) during predevelopment prior to lowering of the potentiometric surface below the land surface (fig. 20D).

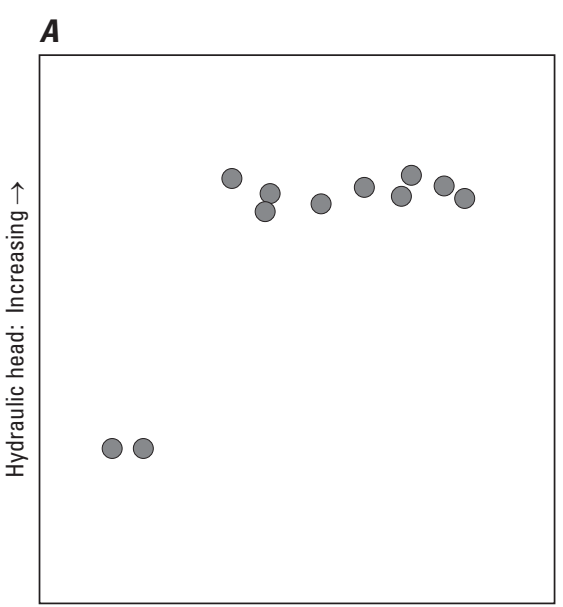

Stratigraphic position: Increasing $\rightarrow$

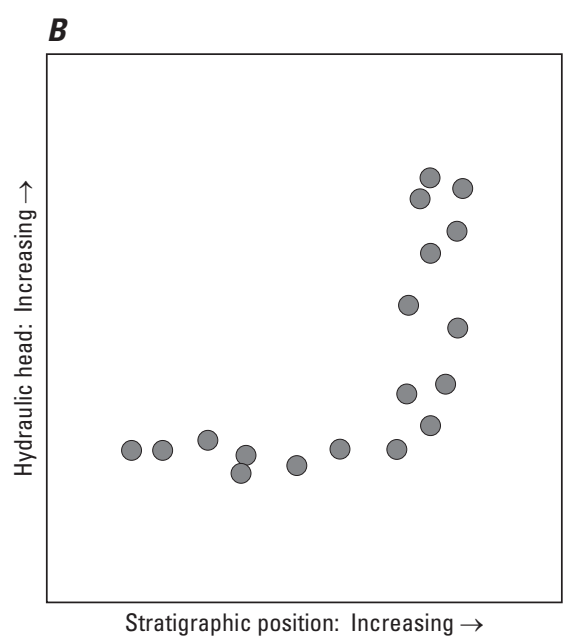

Stratigraphic position: Increasing $\rightarrow$

Figure A2. Combinations of expected patterns of hydraulic head as a function of stratigraphic position. $(A)$ No vertical gradients exist for a thick part of the upper aquifer system (consisting of multiple aquifers), although a significant downward gradient exists in the lower aquifer system; $(B)$ an apparent continuum of heads exists in the upper aquifers, and no vertical gradients exist in the lower aquifers. 
Publishing support provided by the U.S. Geological Survey Publishing Network, Tacoma Publishing Service Center

For additional information contact:

Director, Oregon Water Science Center

U.S. Geological Survey

2130 SW 5th Avenue

Portland, Oregon 97201

http://or.water.usgs.gov 


\section{है}

品

ํㅡㄹ

章

몽

흠

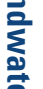

궁

흥

묵

จั

응

흘

든

蛋

艿

을

홍

क

蛋

is

ก.

言

촟

禺

훙 